\title{
INSTRUMENTOS DE PARTICIPAÇÃO DEMOCRÁTICA DIRETA: O PLEBISCITO E O REFERENDO
}

\author{
DISSERTAÇÃO DE MESTRADO
}

ORIENTADOR: PROFESSOR DOUTOR SÉRGIO RESENDE DE BARROS

Faculdade de Direito da Universidade de São Paulo

São Paulo 


\title{
INSTRUMENTOS DE PARTICIPAÇÃO DEMOCRÁTICA DIRETA: O PLEBISCITO E O REFERENDO
}

\author{
Dissertação apresentada à Faculdade de Direito da \\ Universidade de São Paulo como uma das etapas para \\ obtenção do título de Mestre em Direito \\ Área de Concentração: Direito do Estado \\ Orientador: Professor Doutor Sérgio Resende de Barros
}

Faculdade de Direito da Universidade de São Paulo

São Paulo

2013 
Autorizo a reprodução e divulgação total ou parcial deste trabalho, por qualquer meio convencional ou eletrônico, para fins de estudo e pesquisa, desde que citada a fonte.

\section{Serviço de Biblioteca e Documentação Faculdade de Direito da Universidade de São Paulo}

\section{Pinto, Érica Maria Garcia.}

P727i Instrumentos de participação democrática direta : o plebiscito e o referendo / Érica Maria Garcia Pinto. - - São Paulo: USP / Faculdade de Direito, 2013.

$134 \mathrm{f}$.

Orientador: Prof. Dr. Sérgio Resende de Barros.

Dissertação (Mestrado), Universidade de São Paulo, USP, Programa de Pós-Graduação em Direito, 2013.

1. Democracia. 2. Democracia Participativa. 3. Participação Política. 4. Plebiscito. 5. Referendo. I. Barros, Sergio Resende de. II. Universidade de São Paulo, Faculdade de Direito, Programa de Pós-Graduação em Direito. III. Título. 
Nome: Érica Maria Garcia Pinto

Título: Instrumentos de participação democrática direta: o plebiscito e o referendo

Aprovado em:

Dissertação apresentada à Faculdade de Direito da Universidade de São Paulo como uma das etapas para obtenção do título de Mestre em Direito

Banca Examinadora

Prof. Dr.

Instituição:

Julgamento:

Assinatura:

Prof. Dr.

Instituição:

Julgamento:

Assinatura:

Prof. Dr. Instituição:

Julgamento: Assinatura: 
Vox Populi, vox Dei. 


\section{RESUMO}

Diante do descontentamento do povo com seus representantes, nota-se a existência de uma possível crise democrática. Percebe-se haver uma falta de identificação entre as leis vigentes e políticas públicas adotadas com as reais necessidades populares o que gera descrença no sistema e nos políticos, levando o povo, cada dia mais, a se afastar das decisões políticas.

A máxima democrática de que "todo poder emana do povo e deve ser exercido em seu nome", não vem sendo demonstrada no histórico brasileiro, pois, após a eleição, alguns representantes acabam exercendo o poder em benefício próprio, e pior, muitas vezes contra o anseio popular.

A Constituição da República de 1988, seguindo tendência democrática atual, buscou contornar o problema prevendo instrumentos que propiciassem a participação popular de forma direta, sem, contudo, alijar a representação.

Todavia, mais de vinte anos após a promulgação da Constituição, esses mecanismos têm sido pouco utilizados. Assim, o presente estudo tem por objetivo analisar, em especial, os instrumentos da democracia direta que traduzem a vontade popular manifestada nas urnas, quais sejam: o plebiscito e o referendo.

A partir de uma análise histórica da democracia, busca-se entender o porquê da escassez dessas consultas populares, bem como avaliar os meios de que dispõem para conformar o ideal do cidadão às políticas governamentais adotadas por seus representantes. 


\begin{abstract}
Over time there has been an increasing schism between elected officials and the electorade, this causing a crisis of our democracy. This schism strengthens the view among citizens that public policy and enacted laws and regulations do not address popular needs. The result is growing disenchantment with politics itself, leading to distrust of political system, government, and, of course, politicians. This leads to the failure of our democratic system, specifically, lack of plebiscite and referendum.

The principle that "all power emanates from the people and must be exercised on their name" has never been a reality in Brazilian history. Although such a concept may be abstract and difficult to implement, the primary reason for the failure of its implementation is the lack of accountability of politicians to their electorate. Instead, what our democratic society has seen, or at least has perceived, is that politicians do not act to address popular needs; rather, politicians act to address special interests - for themselves personally and for persons with the ability to influence political decisions.

The Constitution, enacted in 1988, sought to address some of these representation failures by providing mechanisms that would encourage, and enable, public participation in a more direct way with their representatives. Almost twenty-five years after the promulgation of the Constitution, it has become obvious that mechanisms have done little to address representation.

The purpose of this thesis is to identify and provide a better understanding of why these representative failures occur and to examine certain instruments of direct democracy that better reflect the popular will expressed and polls by electorate.
\end{abstract}




\section{SUMÁRIO}

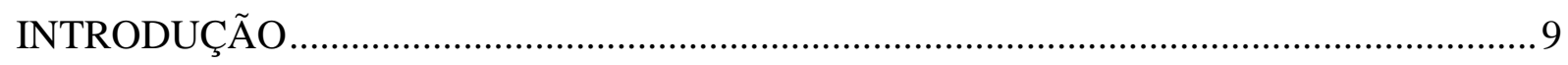

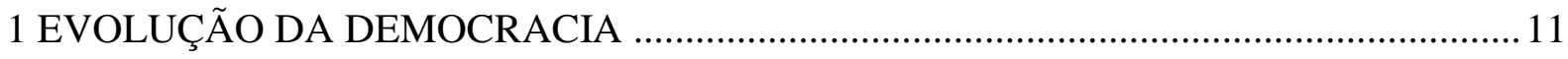

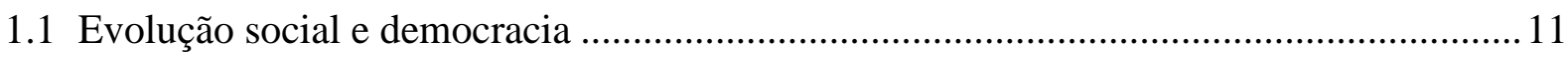

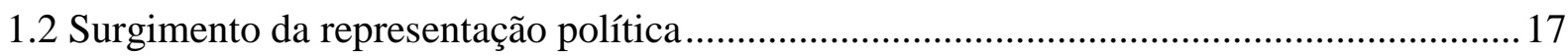

1.3 As revoluções burguesas e a representação política...................................................... 19

1.4 Evolução da representação ..................................................................................... 24

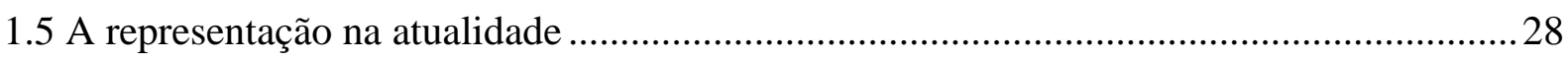

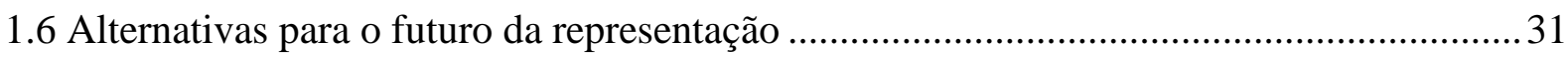

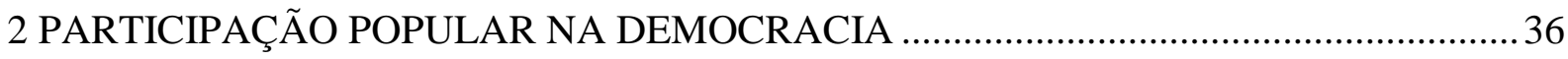

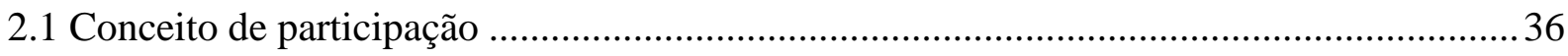

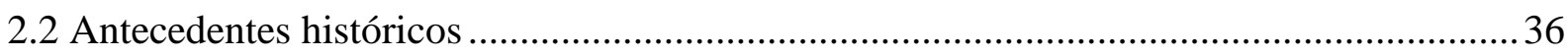

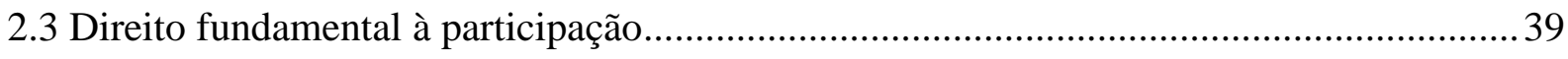

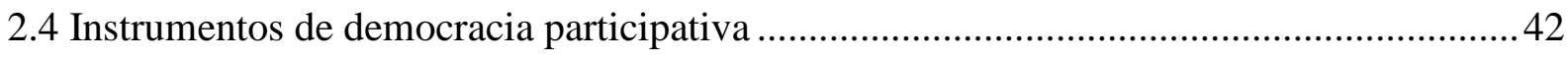

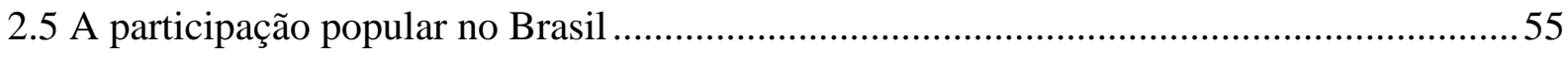

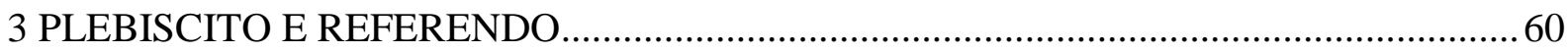

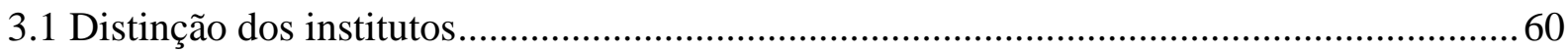

3.2 REFERENDO

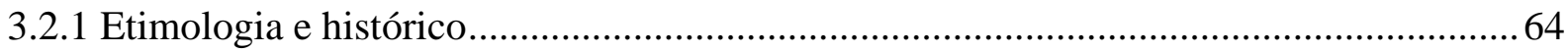

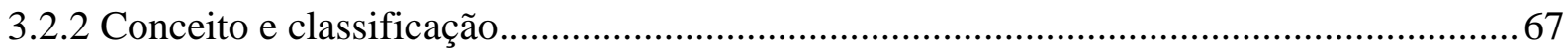




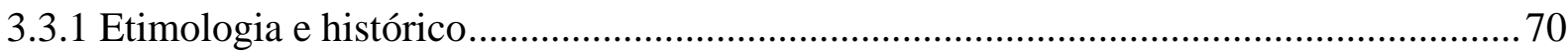

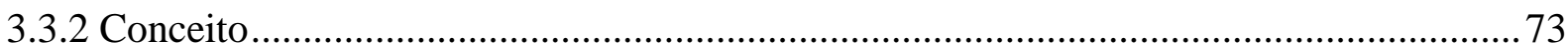

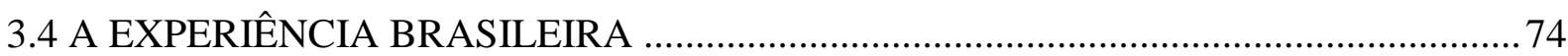

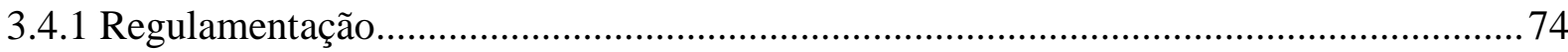

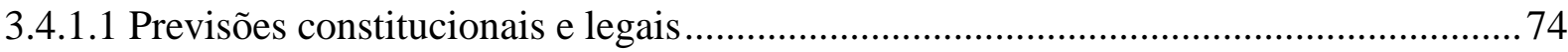

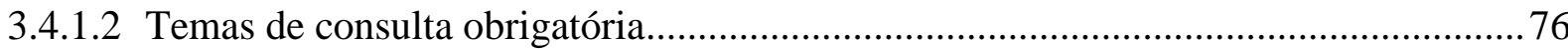

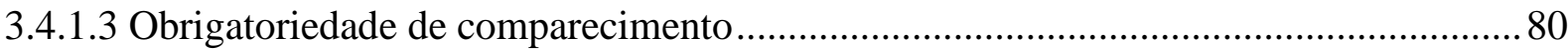

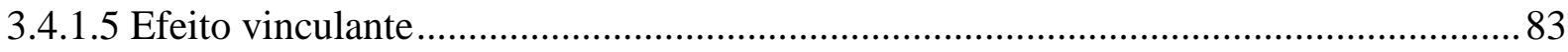

3.4.1.6 Plebiscitos e referendos nas Unidades Federativas .................................................. 90

3.4.1.7 Projetos de alteração da regulamentação ................................................................. 101

3.4.2 Plebiscitos e referendos realizados: a escassez das consultas diretas........................... 104

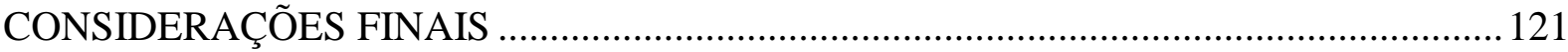

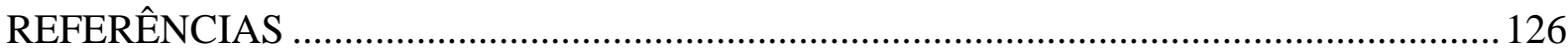




\section{INTRODUÇÃO}

O tema democracia sempre suscita o debate, pois envolve a forma como o poder será exercido. Desde o início da evolução social, quando o homem deixou o nomadismo e passou a se organizar em grupos, percebe-se a importância do compartilhamento do poder entre os sujeitos de uma mesma comunidade.

De outro lado, como forma de governo, a democracia não é um dado natural ${ }^{1}$, ela é produto da evolução histórica das sociedades e de como os indivíduos organizaram a estrutura do poder, tornando-o acessível a todos os cidadãos. Desde sua origem, na Grécia, até os dias de hoje ela passou por transformações históricas impostas pelo próprio meio social.

A democracia, em seu início, praticada na forma direta, permitia a todos os cidadãos a tomada das decisões. Na sua evolução histórica, olvidada por muitos povos, ganhou novamente espaço após o fim do Absolutismo, com as revoluções burguesas, quando surgiu o conceito de representatividade, o que, posteriormente, viria a ser conhecido como democracia indireta, ou aquela exercida por meio de representantes do povo.

Após as atrocidades cometidas na Segunda Guerra Mundial, verificou-se a necessidade de garantir meios dignos de vida aos cidadãos, proclamando-se direitos humanos fundamentais, superiores e anteriores a quaisquer Constituições de Estados. Um desses direitos é a participação política. Sendo assim, constata-se mais um passo na progressão democrática, qual seja, a inserção de mecanismos que garantem ao povo, além de escolher representantes, exercer o poder diretamente, configurando, destarte, a democracia semidireta ou participativa.

Analisando-se as atuais democracias, nota-se haver muitas formas de participação popular democrática, dentre elas, destaque para o plebiscito, o referendo, a iniciativa popular, a revogação de mandatos, o veto popular, o orçamento participativo, entre outros. Nesse estudo, porém, optou-se por dar ênfase apenas àqueles nos quais há a manifestação popular nas urnas, quais sejam, plebiscito e referendo. Não somente a fim de delimitar o objeto de análise, mas pelo potencial que têm na adoção de políticas que, de fato, atendam os anseios

\footnotetext{
${ }^{1}$ Não se deve cair na ideologia do dado, ou seja, ir diretamente ao produto acabado, sem explicar o processo que o produziu, de fundamental importância para a compreensão da evolução da representação política. Sobre a "ideologia do dado", conferir BARROS, Sérgio Resende de. Contribuição dialética para o constitucionalismo. Campinas: Millenium Editora, 2007. p. 22.
} 
populares e, diante disso, pesquisar as causas da pouca utilização desses instrumentos no Brasil

Dessa forma, o primeiro capítulo deste estudo analisa essencialmente o desvirtuamento da representação e os problemas dela decorrentes, como o descrédito popular em seus mandatários eleitos.

O segundo capítulo aborda a participação popular democrática como consequência dos problemas tratados no capítulo inaugural, buscando as origens dessa participação e trazendo uma breve análise dos seus instrumentos.

O terceiro e último capítulo entra diretamente no exame do plebiscito e do referendo, examinando suas origens históricas, suas características mais relevantes e a diferenciação entre ambos. Além disso, trata dessas consultas populares no Brasil, as legislações sobre o tema - incluindo as legislações estaduais -, a análise de casos concretos e projetos que buscam melhorar a utilização de plebiscitos e referendos. 


\section{EVOLUÇÃO DA DEMOCRACIA}

\subsection{Evolução social e democracia}

No início da civilização, os homens eram nômades, viviam em pequenos bandos à caça de alimentos para sua sobrevivência. Somente podemos dizer que a humanidade tem início como civilização a partir do momento em que surgem a agricultura, a domesticação de animais e que a população passa a viver em um mesmo espaço físico.

O elemento histórico a ser considerado como o divisor de águas entre o nomadismo e a fixação em um território foi a prática da escrita, que, por sua vez, levou à formação da aldeia tribal e solidificação da vida em comunidade juntamente com os institutos formadores desta trabalho, propriedade, família, governo, direito ${ }^{2}$.

Assim, teve início a formação das cidades que, para Fustel de Coulanges, têm a família como um de seus elementos constitutivos, descrevendo-as como uma "associação religiosa, mais que associação natural" ${ }^{\prime 3}$. Desse modo, da permissão religiosa para a união de várias tribos (as quais, por sua vez, eram a união de várias fratrias e famílias), foram aparecendo as cidades ${ }^{4}$.

De 800 a 500 a.C., pequenas comunidades começaram a se formar na costa e, outras poucas, no interior da Grécia. De início, eram controladas por reinos locais que, após violentos conflitos, foram substituídos por clãs e tribos ${ }^{5}$. Tais cidades eram basicamente comunidades rurais, as quais, com a expansão das terras e do comércio marítimo, obtiveram crescimento considerável. Crescimento, este que possibilitou também o aparecimento de tiranos, proprietários de terras e comerciantes marítimos. Porém, com o aumento da população, em especial de pequenos e médios proprietários e alguns camponeses, começaram a ser feitas concessões a bem da manutenção do poder. Mais tarde, esse grupo ganhou tamanha importância do ponto de vista militar, colaborando com a proteção da cidade, que esta se tornou uma questão central na estrutura política que estava por vir. ${ }^{6}$

\footnotetext{
2 BARROS, Sergio Resende de. Direitos humanos: paradoxo da civilização. Belo Horizonte: Del Rey, 2003. p. 13

${ }^{3}$ COULANGES, Fustel. A cidade antiga. São Paulo: Martin Claret, 2006. p. 45.

${ }^{4}$ Ibid. pp. 137-138.

${ }^{5}$ HELD, David. Models of democracy. $3^{\mathrm{a}}$ ed. Stanford: Stanford University Press, 2006. p. 11.

${ }^{6}$ Ibid. p. 11-12.
} 
Assim, a estrutura econômica evoluiu para o sistema escravocrata, delineando duas categorias distintas: os cidadãos (originários da cidade) e os demais (escravos e estrangeiros). Sob o aspecto político, códigos escritos e não-escritos também evoluíram, sendo passados através de gerações ${ }^{7}$. Essas cidades-estado ${ }^{8}$ gozavam de autonomia administrativa, política e econômica, circunstâncias tais, que permitiam possuírem legislação própria que regulamentasse seus interesses internos e externos ${ }^{9}$.

A principal dessas cidades-estado foi Atenas, de onde vieram todas as formas de governo experimentadas naquela época: a monarquia (séculos VIII e VII a.C.); a oligarquia (século VII a.C.) e a tirania (560-511 a.C.). Posteriormente, os nobres atenienses, unidos contra a tirania de Pisístrato, começaram a implementar a democracia.

O nobre Clístenes apoiou-se no partido democrático, ganhou a confiança da boule ampliando-a para 500 membros - e criou o demos, uma divisão administrativa na qual podia inscrever-se qualquer cidadão, independentemente da classe social a qual pertencia ${ }^{10}$. É nesse período também que foi criado o ostracismo como um mecanismo de prevenção à tirania. Entretanto, somente no governo de Péricles se deu uma melhor organização à democracia, permitindo o acesso das classes mais pobres à política e a participação de todos ${ }^{11}$.

Os princípios da democracia que começara a se estabelecer em Atenas eram: igualdade de direitos perante a lei, liberdade de conduta (também em conformidade com a lei) e a isegoria - o direito do cidadão expor seu pensamento, suas queixas em público, em grau de igualdade $^{12}$. A democracia ateniense, portanto, é marcada pelo comprometimento com o princípio da virtude cívica, qual seja, dedicação à polis e subordinação da vida privada aos interesses públicos e bem comum ${ }^{13}$.

\footnotetext{
${ }^{7}$ Ibid. p. 12.

${ }^{8}$ A palavra utilizada pelos gregos, à época, era polis. O termo cidade-estado foi utilizado apenas posteriormente. Sérgio Resende de Barros explica que tal fenômeno chama-se "retrospecção", pela qual se aplica a um acontecimento passado um termo atual. BARROS, Sérgio Resende de. Contribuição dialética. cit. p. 41.

9 AZEVEDO, Luiz Carlos de. Introdução à história do direito. $3^{\mathrm{a}}$ ed. rev. e ampl. São Paulo: Revista dos Tribunais, 2010. p. 41.

${ }^{10}$ FINLEY, Moses I. A política no mundo antigo. Trad. Álvaro Cabral. Rio de Janeiro: Zahar, 1985. p. 63.

11 BORGEAUD, Charles. Histoire du plébiscite - le plébiscite dans l'Antiquité: Grèce et Rome. Genebra: George H. Editeur, 1887. pp. 20-21.

12 AZEVEDO, Luiz Carlos de. Introdução à história do direito. cit. pp. 41-42.

${ }^{13}$ HELD, David. Models of democracy. cit. p. 14.
} 
O detentor do poder soberano em Atenas era o demos, caracterizando, destarte, a soberania popular, engajada diretamente nas questões legislativas e judiciais ${ }^{14}$. A organização destas funções se dava, basicamente, por três órgãos: Boulé, Eclésia e Elieu. ${ }^{15}$.

A Boulé, ou Conselho dos 500, composta de cidadãos escolhidos por meio de sorteio 50 de cada tribo - cuidava de questões religiosas, financeiras, diplomáticas e militares, formulando decretos a serem enviados para discussão da assembleia popular.

Já a Eclésia, ou assembleia popular, era aberta a todos os cidadãos, homens, filhos de atenienses que assim o eram ao tempo de Sólon, maiores de 18 anos, e alguns metecos, estrangeiros ou descendentes que ganhavam o status de cidadão pela própria decisão da assembleia $^{16}$. Tratava, ainda, de assuntos de política externa (desde a celebração de tratados e alianças com outras cidades até a declaração de guerra) e, no âmbito interno, questões como armazenamento de cerais, tributação, ostracismo. As votações podiam ser abertas ou secretas, conforme o tema.

A Assembleia se reunia todo ano, geralmente, levando um dia para o debate das questões que seriam postas em votação. Antes, porém, havia discussões envolvendo toda a comunidade, pois esta seria diretamente afetada pela decisão. É certo que havia líderes como Péricles foi durante determinado período - auxiliares dos cidadãos e essenciais para o funcionamento da Eclésia, entretanto, qualquer cidadão poderia opinar e inclusive tornar-se um líder, caso tivesse bom desempenho argumentativo ${ }^{17}$.

Por fim, outro órgão importante era o Elieu, ou Tribunal dos Heliastas, júri popular composto por até seis mil cidadãos, maiores de trinta anos, escolhidos por sorteio. Suas decisões eram definitivas e irrecorríveis, uma vez que eram consideradas interpretações da vontade divina ${ }^{18}$.

Havia, ademais, outros órgãos, como as Magistraturas, dentre as quais se destacam: tesmotetas (revisão das leis e presidir pleitos de ordem pública), eisagogueis (causas comerciais), demarca (zelar pelo cumprimento da justiça, em especial das sentenças proferidas), polemarca (juiz quando a causa envolvia não cidadão, meteco ou estrangeiro).

\footnotetext{
${ }^{14}$ Ibid. p. 14.

${ }^{15}$ AZEVEDO, Luiz Carlos de. Introdução à história do direito. cit. p. 42-43.

${ }^{16}$ FERREIRA FILHO. Manoel Gonçalves. Curso de direito constitucional. 28a . ed. atual. São Paulo: Saraiva, 2002.

${ }^{17}$ FINLEY, Moses I. A política no mundo antigo. cit. p. 92.

${ }^{18}$ BORGEAUD, Charles. Histoire du plébiscite - le plébiscite dans l'Antiquité: Grèce et Rome. cit. p. 16.
} 
Interessante apontar que a democracia ateniense possuía algumas peculiaridades. A lei para os antigos, por exemplo, surgiu como parte da religião. A obra de Sólon era código, constituição e ritual. O primeiro arconte e o rei atenienses tinham funções semelhantes ao pontífice romano. $\mathrm{O}$ arconte zelava pela perpetuidade dos cultos domésticos e o rei dirigia a religião da cidade. Não foi o povo ateniense, assim como os demais povos antigos, que criou suas leis, mas sim a crença religiosa que traziam em $\mathrm{si}^{19}$.

Existia até a possibilidade de ingressar com a graphé paranomon - uma ação de impugnação - para quem entendesse que a Assembleia (Eclésia) contradizia o direito, ou seja, se as leis ali aprovadas afrontassem as normas fundamentais da polis ${ }^{20}$. Se julgada procedente, havia responsabilização tanto de quem propôs a norma quanto do Presidente da Assembleia que permitiu.

Por outro lado, o conceito de igualdade, perante a lei ou o direito, significa que o cidadão deve ter acesso à tomada de decisões ou às funções. Desse modo, o sorteio surgiu como método mais democrático, pois colocava todos os cidadãos em pé de igualdade ${ }^{21}$. Ressalvando-se, porém, que em alguns casos, após o sorteio, o cidadão passava por um exame, através do qual se identificava se ele tinha condições sociais, morais e religiosas para assumir a função ${ }^{22}$. Os atenienses (e Aristóteles, inclusive) consideravam a eleição um meio aristocrático - utilizando-se da acepção original do termo aristocracia, qual seja, o governo dos mais qualificados. É certo, entretanto, que algumas funções, como a Magistratura Militar, por demandarem habilidades específicas, não eram escolhidas por sorteio e sim por eleição. Pode-se daí extrair a ideia de governo misto ${ }^{23}$.

\footnotetext{
${ }^{19}$ COULANGES, Fustel. A cidade antiga. cit. pp. 206-208.

${ }^{20}$ HUME, David apud FINLEY, Moses I. A política no mundo antigo. cit. p. 70.

${ }^{21}$ ARISTÓTELES apud FINLEY, Moses I. A política no mundo antigo. cit. p. 35.

${ }^{22}$ COULANGES, Fustel. A cidade antiga. cit. p. 354.

${ }^{23}$ Em várias passagens de "A Política", Aristóteles faz comparações entres as formas de governo, atribuindo à eleição um caráter oligárquico (relacionado à aristocracia), como o faz em: "Outros dizem que o governo em Esparta é uma oligarquia, porque nele se encontravam várias instituições oligárquicas. Todas as funções lá são eletivas, sem haver uma só que seja conferida por sorte (...)" Mais adiante, nas explicações sobre os métodos deliberativos de cada forma de governo, explica que na democracia "haveria vantagem, também, em só admitir às deliberações cidadãos eleitos ou escolhidos por sorte, igualmente em todas as classes. Finalmente, seria de utilidade, no caso em que o número de homens ultrapassasse em muitos o dos homens instruídos e hábeis na ciência de governar, não conceder retribuição a todos, e sim a tantos pobres quantos fossem os ricos, ou então fazer escolher pela sorte uma certa quantidade de pobres que tomariam parte nas deliberações". Nota-se em todos os casos que Aristóteles não considera a democracia como melhor forma de governar, mas ao introduzir nela elementos aristocráticos, propõe melhoras. In: ARISTÓTELES. A política. Trad. Nestor Silveira Chaves. $2^{\text {a }}$ ed. rev. Bauru: Edipro, 2009. pp. 138 e 150.
} 
Ademais, a igualdade era um direito apenas do cidadão ateniense, sendo que mulheres, estrangeiros e principalmente escravos não tinham quase nenhum direito. As mulheres não tinham direitos políticos e seus direitos civis eram extremamente limitados, embora se reconhecessem algumas vantagens para as mulheres casadas em detrimento das solteiras ${ }^{24}$. Os estrangeiros, de tal sorte, não podiam sequer cobrar a dívida de um cidadão ateniense, uma vez que a lei não reconhecia a validade do contrato ${ }^{25}$.

Outra peculiaridade, em Atenas, é a liberdade individual. Aquela liberdade proclamada pela democracia era a participação de todos nas decisões, pois, embora houvesse grande liberdade para as questões políticas, havia extrema sujeição ao Estado, restringindo a liberdade individual. Devendo-se isso ao domínio absoluto da religião ou do Estado, ou ambos, quando estes se confundiam, sobre a sociedade ${ }^{26}$.

Havia ingerência do Estado em muitas das questões privadas. Em Atenas, as leis da cidade não permitiam que as mulheres levassem mais do que três vestidos em viagens. Em Esparta, após a derrota de Leuctra, os pais dos cidadãos mortos na batalha deveriam demonstrar felicidade, de modo que o Estado se sobrepunha até aos sentimentos naturais ${ }^{27}$.

Não havia liberdade de crença. $\mathrm{O}$ homem tinha de se submeter à religião da cidade. Se, por acaso, ofendesse as leis e a religião, a punição era severíssima ${ }^{28}$. Por esse motivo, por não aceitar os deuses da cidade e corromper a juventude, Sócrates foi condenado a tomar a cicuta - pois, na qualidade de cidadão ateniense, não poderia ser executado.

Uma sanção muito conhecida na democracia ateniense era também um ato contra a liberdade. Trata-se do ostracismo, pelo qual cidadãos considerados nefastos ao interesse público eram condenados ao exílio. O nome ostracismo tem origem nas votações secretas das regiões litorâneas, onde os cidadãos utilizavam a parte lisa das ostras para marcar seu voto ${ }^{29}$.

Sendo assim, devido a exemplos como esses, a democracia era alvo de muitas críticas, algumas até a denominavam como a "tirania dos cidadãos"30.

\footnotetext{
${ }^{24}$ HELD, David. Models of democracy. cit. p. 19.

${ }^{25}$ COULANGES, Fustel. A cidade antiga. cit. p. 212.

${ }^{26}$ Ibid. p. 248.

${ }^{27}$ Ibid. p. 249.

${ }^{28}$ Ibid. p. 251.

${ }^{29}$ AZEVEDO, Luiz Carlos de. Introdução à história do direito. cit. p. 43.

${ }^{30}$ HELD, David. Models of democracy. cit. p. 19.
} 
Tomando por base esses elementos, Benjamin Constant escreveu um estudo comparando a liberdade dos antigos e dos modernos, concluindo que a liberdade para um cidadão ateniense consistia na partilha do poder social entre todos os cidadãos de uma mesma pátria. Já para os modernos, a liberdade é a segurança dos privilégios privados, é o direito de submeter-se à lei, não se sujeitando à vontade arbitrária de um ou vários indivíduos ${ }^{31}$.

Para os gregos não havia distinção entre vida pública e privada. Werner Jaeger bem pontuou que "um código puramente privado, sem referência ao Estado, era inconcebível para os gregos". Hannah Arendt destaca que o "livre-arbítrio" jamais fora pensado nas sociedades gregas, assim como em toda Antiguidade clássica. O conceito de indivíduo apareceu somente com o cristianismo, tendo sido desenvolvido pelo Iluminismo ${ }^{32}$.

Além dessas, lembramos algumas peculiaridades que proporcionaram êxito à democracia ateniense ${ }^{33}$ :

1. Pequena extensão territorial

2. Escravismo, visto que proporcionava tempo livre aos cidadãos. Embora Péricles, em seu discurso em homenagem aos mortos na primeira batalha da Guerra do Peloponeso, tenha ressaltado que "nossos homens públicos, além da política, possuem atividades privadas, e nossos cidadãos, ainda que ocupados nos seus negócios, são julgadores sensatos das questões públicas" ${ }^{, 34}$, é certo que o desenvolvimento da maioria dos trabalhos pelos escravos, permitia aos cidadãos tempo para cuidar das questões públicas.

3. Número restrito de cidadãos participantes da democracia. Calcula-se que para cada dois cidadãos livres, havia três escravos, chegando esses a um montante de 80 a 100 mil $^{35}$. Ademais, excluindo, escravos, mulheres e estrangeiros, os cidadãos ativos na democracia, não passavam de $10 \%$ da população ${ }^{36}$.

\footnotetext{
${ }^{31}$ CONSTANT, Benjamin. De la liberte des anciens comparée a celle des modernes - Discours prononcé a L'Athéné Royal de Paris. In: Colletion compléte des ouvragres. $4^{\circ}$ vol. Paris:Imprimerie de J. L. Chanson, 1820. p. 253

32 SARTORI, Giovanni. Teoria da democracia revisitada. Volume II - As questões clássicas. Trad. Dinah de Abreu Azevedo. São Paulo: Editora Ática, 1994. pp. 42-43.

${ }^{33}$ HELD, David. Models of democracy. cit. p. 27.

34 PÉRICLES. Discurso de Péricles. $\quad$ Disponível em <http://www.historianet.com.br/conteudo/default.aspx?codigo=1124>. Acesso em 23 mar. 2011.

${ }^{35}$ HELD, David. Models of democracy. cit. p. 19.

${ }^{36}$ FERREIRA FILHO, Manoel Gonçalves. Curso de direito constitucional... p. 82.
} 


\subsection{Surgimento da representação política}

Ultrapassando-se a Idade Antiga, especialmente no que concerne à democracia direta ateniense, surgem na Idade Média as primeiras manifestações do que viria a ser mais tarde um sistema representativo ${ }^{37}$.

A representação política corresponde a um arranjo político-constitucional em cujos quadros os governantes são eleitos pelos integrantes do corpo social e considerados seus representantes $^{38}$. Sendo assim, a representação política implica numa transmutação do polo do exercício do poder político, operação que, no Estado de Direito, se realiza por força de regras preestabelecidas que atribuem a um organismo abstrato e diferente dos indivíduos titulares desse poder, que, porém, intervém através da seleção dos integrantes daquele organismo ${ }^{39}$.

No tocante ao surgimento, há quem defenda a origem longínqua da representação política, ousando vislumbrar embriões da representação nos colégios sacerdotais ou conselhos de patriarcas - aqueles que assessoravam os monarcas orientais ${ }^{40}$.

Como visto no item anterior, na Grécia, durante o período clássico, a democracia era praticada pelos cidadãos de Atenas e de outras cidades-estado na sua forma direta, mas havia também a adoção da representação política que ocorria por meio de sorteio ou mesmo eleição dos representantes das eclesias. De outro lado, na república e no principado romano vigorava o princípio da soberania popular, assim, o povo conferia ao imperador um mandato permissivo ao acúmulo de todas as magistraturas ${ }^{41}$.

Já na Idade Média, devido às longas distâncias, as ordens religiosas não podiam deslocar todos os seus membros a Roma para votar, portanto, enviavam seus mandatários para que eles exprimissem a vontade geral do grupo perante os concílios. Esses mandatários, no entanto, eram apenas porta-vozes, pois somente repetiam nos concílios a decisão já previamente tomada nos mosteiros e nas ordens.

\footnotetext{
${ }^{37}$ BASTOS, Celso Ribeiro. Curso de teoria do estado e ciência política. $2^{\text {a }}$. ed. São Paulo: Saraiva, 1989. p. 52.

${ }^{38}$ FERREIRA FILHO, Manoel Gonçalves. Curso de direito constitucional ... p. 85.

${ }^{39}$ CAGGIANO, Monica Herman Salem. Sistemas eleitorais x representação política. Brasília: Senado Federal, 1990. p. 19.

${ }^{40}$ MENEZES, Aderson de. Teoria geral do Estado. $8^{\mathrm{a}}$ ed. $4^{\mathrm{a}}$ tiragem. Atual. José Lindoso. Rio de Janeiro: Forense, 2002. p. 290.

${ }^{41}$ Ibid. p. 291.
} 
Nessa mesma época, no século XII, a Inglaterra, tradicional exportadora de modelos, também adotou o sistema representativo. Inicialmente, foi a Câmara dos Lordes, sempre ouvida pelo rei antes de qualquer regulamentação importante. Essa prática se consolidou e começou a ser aplicada regularmente pelo Rei Eduardo I na reunião do Magnum Concilium. Posteriormente, em meados do século XIII, foi instalada a Câmara dos Comuns (House of Commons), com representantes da baixa nobreza. A partir desse momento, houve a formação do Parlamento inglês, constituído pelo rei, Câmara dos Lordes e House of Commons. Aduz-se, assim, que o modelo medieval de representação se dava pela transposição do mandato civil para o direito público, guardando estreita vinculação entre representante e eleitor ${ }^{42}$. Devido a essa vinculação, ficou conhecido como mandato imperativo.

Cumpre ressaltar que a representatividade medieval não se aplicava apenas em razão das distâncias físicas. Havia também a dificuldade em reunir várias pessoas para pleitear um a um diante do rei e, ainda, a questão da falta de conhecimento sobre certas matérias ${ }^{43}$.

Ademais, ainda no período medieval, as cortes, na península ibérica, ou estados gerais, na França, convocados pelo rei como consilia regis (conselhos do rei), tinham caráter estamental (pois representavam classes da sociedade) privado, sendo reunidos esporadicamente (às vezes passavam séculos entre uma e outra reunião), sem poder ou caráter deliberativo $^{44}$.

Aí está mais uma razão para defender que, à época, o mandato era específico para representar um interesse particular, motivo pelo qual o representante defendia os interesses do grupo que o enviou.

Contrapondo-se ao modelo representativo inglês, no século XII, surgiram na Suíça suas primeiras formas de democracia direta, principalmente nas regiões próximas à Itália, pois, para resolver os problemas locais, os habitantes se reuniam em concílios. Já no século

\footnotetext{
${ }^{42}$ CAGGIANO, Monica Herman Salem. Sistemas eleitorais. cit. pp. 15-16.

${ }^{43}$ JOUVENEL, Berttrand de. As origens do Estado Moderno - Uma história das idéias políticas no século XIX. Rio de Janeiro: Zahar Editores, 1978. pp. 328 e seg.

${ }^{44}$ CARLYLE, R. W. e CARLYLE ,A. J. A History of Medieval Political Theory in the West. Vol. II. Cap. IX. Blackwood: London, 1950. Disponível em: <http://pt.scribd.com/doc/33821002/A-History-of-MediaevalPolitical-Theory-in-the-West-Vol-02>. Acesso em: 8 set. 2011.
} 
XIII, foram criadas, em alguns cantões da parte alemã, as Landsgemeiden - que se reuniam geralmente uma vez por ano para eleger autoridades, editar leis, declarar guerra, etc. ${ }^{45}$

\subsection{As revoluções burguesas e a representação política}

No fim da Idade Média, o modo de produção feudal, caracterizado pelo isolamento e economia de subsistência, gerou acúmulo de terras, tanto por parte dos pequenos proprietários quanto pelos grandes latifundiários. Todavia, o governo dos monarcas era criticado, pois as altas tributações impostas à população favoreciam o estado de guerra, que só servia para prejudicar o desenvolvimento econômico e social ${ }^{46}$.

Assim, esses monarcas da Idade Média, apoiados pela Igreja Católica, foram perdendo prestígio. Assim, se originaram as monarquias absolutas, nas quais o poder se concentrava no soberano, com o fim de agregar as populações dispersadas nos feudos e propiciar uma convivência pacífica.

Com o advento do modo de produção capitalista, primeiro no mercantilismo e posteriormente na fase industrial, percebeu-se ter havido uma dicotomia entre os agentes políticos e econômicos. No início da Idade Moderna, os agentes econômicos eram a burguesia, enquanto os agentes políticos, a nobreza e o alto clero ${ }^{47}$. Daí evidenciou-se a separação entre sociedade civil e Estado, representando, respectivamente, a classe econômica e a classe política.

Além disso, o que mais ocorreu nessa fase foi a grande concentração de poder nas mãos dos monarcas absolutos, os agentes políticos, que acabavam por explorar a burguesia, principal agente econômico daquela sociedade.

Resultado dessa concentração de poderes ilimitados, ficou conhecida a célebre frase do rei da França, Luís XIV, o "Rei Sol”, l'État c'est moi, representando a unipersonalidade entre monarca e Estado.

\footnotetext{
${ }^{45}$ PAPADOPOULOS, Yannis apud AFONSO DA SILVA, José. O sistema representativo e a democracia semidireta: democracia participativa. In: Revista do Advogado da Associação dos Advogados de São Paulo. n. ${ }^{\circ} 73$. Nov 2003. p. 96.

${ }^{46}$ DALLARI, Dalmo de Abreu. Elementos de teoria geral do Estado. $21^{\mathrm{a}}$ ed. atual. São Paulo: Saraiva, 2000. p. 70.
} 
De outro lado, contudo, há registros de que os soberanos não foram tão absolutos quanto possa parecer, pois dependiam das leis por eles criadas, ou ao menos, mantidas, de forma que eram instrumentos da tradição e em nome dela ficavam obrigados a se curvar diante de resistências legítimas ${ }^{48}$.

Certo é que houve reações contra o absolutismo, as chamadas revoluções burguesas, motivadas, principalmente, pela pesada tributação, imposta pelos monarcas, ao desenvolvimento econômico e social da burguesia. Essas revoluções começaram no século XVII, com a Revolução Gloriosa Inglesa, que, embora depusesse um rei (o católico Jaime II) e entregasse o trono a dois outros monarcas protestantes (Maria II, sua filha, e o marido dela, Guilherme III, da Holanda), restringiu o poder desses últimos, por meio do Parlamento.

Desse modo, pode-se perceber que a mais conservadora das revoluções foi também a mais liberal, pois seu intuito não era acabar com a lei, mas sim confirmá-la de modo que um rei violador da legislação passasse a respeitá-la. A intenção "revolucionária" era "dar liberdade pela e sob a lei"

Thomas Hobbes confirma essa limitação do poder dos representantes do corpo político pela lei:

[...] é preciso que leis ordinárias, comuns a todos os súditos, determinem o que é legítimo aos representantes fazer $[\ldots]$

Num corpo político, se o representante for um só homem, qualquer coisa que faça da pessoa do corpo, que não seja autorizada pelas suas cartas ou pela leis, é seu próprio ato, e não ato do corpo, nem de nenhum dos membros deste além dele mesmo. Porque para além dos limites estabelecidos pelas suas cartas e pelas leis ele não representa a pessoa de ninguém, a não ser a dele próprio. Mas aquilo que ele fizer de acordo com elas será o ato de todos, pois do ato do soberano todos são autores, dado que ele é o seu representante ilimitado. E o ato do representante que não divergir das cartas do soberano será um ato do soberano; logo, cada um dos membros do corpo é seu autor. ${ }^{50}$

Somente um século depois a revolução, que antes ocorrera na ilha britânica, chegou ao continente, tendo na França seu mais importante capítulo. Principalmente a partir da segunda metade do século XVIII, duas mudanças transformaram a história: a Revolução Industrial e o Iluminismo. Por um lado, a revolução industrial, com a implementação do capitalismo (na

\footnotetext{
${ }^{47}$ BARROS, Sergio Resende de. Estado de legalidade. Apostila da disciplina "A negação do Estado de direito pelo Estado de legalidade". Curso de Pós-Graduação da Faculdade de Direito da Universidade de São Paulo. $2^{\circ}$ semestre de 2009. p. 7.

${ }^{48}$ CALMON, Pedro apud MENEZES, Aderson de. Teoria geral do Estado. cit. p. 119.

${ }^{49}$ TKEVELYAN, G. A revolução inglesa. Brasília: Editora UnB, 1982. p. 6 e seg.
} 
fase inicial caracterizada pelo mercantilismo), acabou de vez com o feudalismo e sua economia agrária, de outro lado, o movimento filosófico iluminista pregava a razão e com ela o fim da ideia do direito divino dos reis. Assim, começa o declínio da monarquia e da aristocracia como um todo, abaladas em seu poder político e econômico, abrindo espaço para emergir a classe burguesa.

Entretanto, a ascensão de uma nova classe como a burguesia só seria viável se: I) controlasse e reduzisse os poderes monárquicos absolutos; II) banisse os privilégios aristocráticos medievais; III) assegurasse o livre mercado, sem interferência estatal e IV) introduzisse leis que coibissem o poder regulador do absolutismo. Esse conjunto de ideias e aspirações ficou conhecido como Liberalismo.

$\mathrm{Na}$ Inglaterra, a principal vertente liberal foi na economia. Baseada, principalmente, nas ideias de Adam Smith, o liberalismo preservou a monarquia, mas a deixou totalmente limitada pelo parlamento - "o rei reina, mas não governa". Na França, de outro lado, o foco liberal foi social, pois lá os valores aristocráticos feudais estavam muito arraigados. Aliás, a abolição dos privilégios é, na concepção de Hegel, uma das maiores conquistas da Revolução Francesa. Na visão hegeliana os membros do Estado não deveriam atuar baseados em privilégios de indivíduos e corporações, mas sim com base no dever, enquanto coletividade, visando o bem de todos ${ }^{51}$. Nesse passo, é que houve a intensa luta burguesa para assumir o controle político, usando o parlamento como instrumento.

Conclui-se, dessa forma, que a representação política, na precisa acepção do termo, surgiu mesmo da reunião de dois fatores, quais sejam: a formação de uma unidade política estatal (Estado moderno) e o liberalismo - substituto do absolutismo ${ }^{52}$.

É importante ressaltar que se, na sua origem, a burguesia francesa tinha a intenção de tomar o controle político pelo parlamento (poder legislativo), no desenrolar da história, pretendia também obter o domínio do poder executivo, alijando a monarquia. Desse modo, pois, o poder estaria nas mãos dos representantes do povo.

\footnotetext{
${ }^{50}$ HOBBES, Thomas. Leviatã, ou Matéria, forma e poder de um estado eclesiástico e civil. Org. Richard Tuck. Trad. João Paulo Monteiro [et al.]. 2a ed. São Paulo: Martins Fontes, 2008. pp. 192-193.

51 In: BOBBIO, Norberto. A teoria das formas de governo. Trad. Sérgio Bath. 10 a ed. Brasília: Editora Universidade de Brasília, 2000. p. 159.

${ }^{52}$ MIRANDA, Jorge. Manual de direito constitucional. Tomo III. $5^{\mathrm{a}}$ ed. rev. atual. Coimbra: Coimbra Editora, 2004. p. 362.
} 
Nesse ponto chega-se ao principal marco histórico que a Revolução Francesa trouxe para o instituto da representação. Ora, se foi a burguesia que liderou todo Terceiro Estado na tomada do poder, nada mais justo que ela fosse sua representante. Mas como faria isso? Foi aí que surgiu a ideia de representação política.

Neste período, Sieyès escreveu a obra Qu'est-ce le Tiers État?, apresentando o conceito de nação como um novo sujeito no contexto político, e mudando o pensamento de que o representante exprimiria apenas a vontade de um grupo de indivíduos, passando a representar a nação, entidade abstrata que é a verdadeira detentora da soberania e não o povo. A nação é, portanto, "um corpo de associados que vivem sob uma lei comum e representados por uma mesma legislatura ${ }^{53}$.

Nesse mesmo sentido, de os eleitos representarem a nação e não aquela parcela do povo que os elegeu, estão as ideias de Edmund Burke e Montesquieu. Burke, no célebre discurso aos eleitores de Bristol, em 3 de novembro de 1774, e Montesquieu, em Do Espírito das Leis: "não é necessário que os representantes, que receberam daqueles que os escolheram uma instrução geral, recebam uma instrução particular sobre cada assunto, como é praticado nas dietas da Alemanha" $" 54$.

Convém destacar, entretanto, que, antes de Sieyès, Montesquieu e Burke, Robert Filmer, na obra Patriarca (publicação póstuma em 1680), já perfilhava a mesma ideologia representativa: "ele (o povo) deve somente escolher e confiar naqueles que escolheu para fazer o que eles programam,"55.

Raymond Carré de Malberg distingue algumas das principais mudanças no sistema representativo antes de 1789 e após a primeira assembleia constituinte francesa, explicando que antes o deputado levava o voto de seus representados e as deliberações eram tomadas pelo monarca, ao passo que, depois, os deputados ganharam independência e o poder legislativo delibera por si próprio, por meio das leis ${ }^{56}$.

\footnotetext{
${ }^{53}$ No original: "um corps d'associés vivant sous une loi commune et representes par la même législature". SIEYÈS, Emmanuel. Qu'est-ce que le tiers état? Société de l'Histoire de la révolution française. Paris, 1888. p. 31. (traduzi)

${ }^{54}$ MONTESQUIEU, Charles-Louis de Secondat. Do espírito das leis. Trad. Edson Bini. Bauru: EDIPRO, Série Clássicos, 2004. p. 192.

${ }^{55}$ FILMER, Robert apud BARROS, Sérgio Resende de. Contribuição dialética. cit. p. 30-31.

${ }^{56}$ MALBERG, Raymond Carré de. Teoría general del Estado. Trad. José Lión Depetre. México: Fondo de Cultura Económica, 2001. pp. 985-986.
} 
Malberg continua sua investigação comparando o parlamento a um órgão do Estado, mas não como explicado na teoria de Gierke, segundo a qual o órgão expressa a vontade da coletividade pré-existente ao próprio surgimento desse órgão. Para o autor, o órgão é, sim, indispensável, pois do contrário haveria somente vontades individuais divergentes, inseguras, obscuras e insuscetíveis de tornarem-se uma só, por isso os constituintes de 1789-1791 afirmavam que o "representante quer pela nação, não se limitando a traduzir a vontade coletiva que está no seio da nação, senão que as decisões emitidas por ele (órgão) constituem, de uma maneira inicial, a vontade nacional" ${ }^{\prime 57}$.

Sendo assim, o autor afirma que, antes mesmo dos autores alemães (Gierke e Jellinek), os constituintes franceses já aplicavam a teoria, porém sem utilizar a palavra "órgão", cunhada posteriormente pelos alemães. Isso se deu em razão da utilização errada da palavra representação, pois, embora houvesse o caráter representativo, já que a nação, através da Assembleia Constituinte, superior ao parlamento, poderia destituí-lo; de outro lado, o corpo legislativo queria livremente pela nação, sem determinações prévias ou ratificações posteriores, caracterizando assim a independência do órgão ${ }^{58}$.

Corroborando a posição de Hobbes e a teoria de Malberg, Rosanvallon explica que, no período pós-revolucionário, Guizot e "les doctrinaires", os defensores da monarquia, atribuíram a "fase do terror" ao ingresso do povo nas decisões políticas e propugnavam que a vontade desenfreada pela soberania é que conduzira a França à catástrofe. Portanto, propuseram a escolha de representantes que pudessem exprimir a vontade geral, contudo utilizando-se de artifícios que, ao passo que os distanciassem dos representados, os fizessem capazes de filtrar as irracionalidades do povo ${ }^{59}$.

Destarte, pode-se concluir que duas alterações fundamentais ocorreram. A primeira é que os representantes não mais apenas pleiteavam pelos seus eleitores, mas também decidiam por eles. E a segunda é que, se antes os parlamentos representavam os eleitores perante o soberano, agora, sendo órgão do próprio Estado, passam a exercer parte dessa soberania. Sendo assim, Manoel Gonçalves Ferreira Filho explica que o verdadeiro soberano era o Parlamento $^{60}$.

\footnotetext{
${ }^{57}$ Ibid. pp. 993-996. Traduzi.

${ }^{58}$ Ibid. pp. 1000-1005.

${ }^{59}$ ROSANVALLON, Pierre. La démocratie inachevée - Histoire de la souveraineté du peuple em France. Paris: Gallimard, 2000. pp. 103-111.

${ }^{60}$ FERREIRA FILHO, Manoel Gonçalves. A democracia possível. 5a . ed.. São Paulo: Saraiva, 1979. p. 12.
} 
Outro instituto importante para garantir o mandato independente é a imunidade parlamentar. Esta possui duplo aspecto: inviolabilidade pessoal e irresponsabilidade legal. A inviolabilidade pessoal não permite que o parlamentar seja preso ou processado sem prévia licença. Já a irresponsabilidade legal isenta-o por suas palavras, suas opiniões e seus votos, emitidos no exercício de seu cargo. A imunidade não é tida como privilégio, mas como garantia ao parlamentar.

Na Assembleia Constituinte francesa de 1789, Mirabeau já pleiteava a imunidade para os representantes ali presentes. Todavia, a origem da imunidade parlamentar, propriamente dita, é inglesa. O freedom of speech, ou liberdade de opiniões, remonta ao ano de 1397, no caso Haxey, pois esse parlamentar foi preso por ser autor de uma lei que reduzia as despesas da casa real; prisão essa, que dois anos mais tarde foi julgada ilegal. Já o freedom from arrest tem origem em 1603, quando, por ordem do rei, foi preso o deputado Thomas Shirley, o qual só fora solto por intervenção do presidente da Câmara dos Comuns, o Speaker ${ }^{61}$.

\subsection{Evolução da representação}

O Terceiro Estado, aproximadamente, noventa e cinco por cento da população francesa à época, tinha lutado acirradamente para obter uma representação maior que a do clero e da nobreza. Diferentemente do corpo feudal tradicional que votava por classes ou estamentos (um voto para a nobreza, um voto para o clero e um voto para o Terceiro Estado), na Assembleia pretendida pelos revolucionários os votos seriam proporcionais ao número de representantes de cada classe social ${ }^{62}$.

Contudo, na Revolução, o Terceiro Estado foi liderado pela burguesia economicamente, a classe mais poderosa; e ela não deixaria que camponeses e trabalhadores pobres, analfabetos e mal instruídos politicamente, colocassem tudo a perder. Desse modo, a burguesia, então, se "apoderou" do parlamento, a fim de cumprir os objetivos liberais. E, assim, o fez através do voto censitário.

A maioria dos deputados burgueses acolheu a proposta de Mounier, a qual instituía o censo eleitoral e a distinção entre cidadãos ativos e passivos, nos termos da proposta de

\footnotetext{
${ }^{61}$ MENEZES, Aderson de. Teoria geral do Estado. cit. pp. 297-299.

${ }^{62}$ HOBSBAWM, Eric J. A Era das revoluções: Europa 1789-1848. Trad. Maria Tereza Lopes Teixeira e Marcos Penchel. $12^{\mathrm{a}}$ ed. Rio de Janeiro: Paz e Terra, 2000. p. 78.
} 
Sieyès na Assembleia Constituinte. Os cidadãos passivos eram aqueles que não tinham condições de pagar o censo estabelecido e, portanto, não podiam votar e nem ser eleitos para cargos públicos. Já os cidadãos ativos eram os homens, maiores de 25 anos, subdivididos em três categorias: os que pagassem a contribuição de três jornadas de trabalho tinham direito de indicar eleitores; os que contribuíssem com dez jornadas eram os eleitores e, por fim, os que pagassem o "marco de prata" (cerca de 54 libras) e que possuíssem propriedades territoriais eram os que poderiam ser deputados ${ }^{63}$.

Por esse motivo, Manoel Gonçalves Ferreira Filho assevera que essa democracia tinha caráter oligárquico, uma vez que os representantes do povo eram escolhidos nas altas camadas sociais - pois só elas poderiam arcar com o censo eleitoral - deixando à margem a maior parte da população. Desse modo, se fazia presente a oligarquia na acepção própria da palavra, ou seja, governo da minoria formado pelos mais ricos. O autor conclui que a democracia representativa implementada pela burguesia francesa "era o governo de alguns, de acordo com suas próprias opiniões, embora esses poucos que governassem fossem eleitos pelo 'povo', por um povo mais ou menos amplamente definido" 64 .

Embora essa proposta sobre a representação fosse rejeitada por deputados como Maximilien Robespierre, discípulo das ideias de Rousseau, a maioria dos deputados burgueses a acolheu. Assim, a França, que tinha cerca de 26 milhões de habitantes, restava apenas com pouco mais de 4 milhões de eleitores. Curioso é que situação semelhante ocorrera na Grécia em sua época democrática. Em Atenas havia um número restrito de cidadãos participantes. A proporção era de três escravos para cada dois cidadãos livres, o que somava um número de 80 a 100 mil escravos no total ${ }^{65}$. Ademais, excluindo escravos, mulheres e estrangeiros, os cidadãos ativos na democracia não passavam de $10 \%$ da população ${ }^{66}$.

Não foi outro o modelo praticado na Constituição Política do Império do Brasil de 1824. Nas eleições primárias (à época, as eleições eram em dois graus) podiam votar os que tivessem de renda líquida anual 100 mil réis, por "bens de raiz, indústria, comércio ou emprego" (art. 92, inciso IV) e nas eleições de deputados, senadores e assembleias provinciais, votavam aqueles que tivessem de renda de 200 mil réis (art. 94, inciso I). Já, para que pudesse concorrer ao cargo de deputado, a exigência era ainda maior: uma renda anual de

\footnotetext{
${ }^{63}$ MANFRED, A. A grande revolução francesa. Trad. Maria Aparecida de Camargo e Antonia da Costa Simões. $2^{\mathrm{a}}$ ed. São Paulo: Cone, 1986.

${ }^{64}$ FERREIRA FILHO, Manoel Gonçalves. A democracia possível. cit. pp. 12-13.

${ }^{65}$ HELD, David. Models of democracy. cit. p. 19.
} 
400 mil réis (art. 95, inciso I), e para senadores renda de 800 mil réis, além da idade mínima de 40 anos (art. 45, incisos I e IV).

$\mathrm{Na}$ verdade, foram os Estados Unidos da América a primeira nação a implantar o modelo democrático-representativo tal como conhecemos hoje. Após a independência das colônias, em 1776, os pensadores federalistas - James Madison, Alexander Hamilton e John Jay - estudavam um modelo governamental que se diferenciasse do modelo monárquico europeu $^{67}$, baseado na separação de poderes e na inovadora forma federativa de Estado.

Mas, assim como os outros sistemas representativos da época, o modelo norteamericano também foi pautado pelo voto censitário, porém, inovara pela participação de partidos políticos, os quais, por sua vez, ficaram responsáveis pela organização dos desejos populares e pela veiculação da opinião pública. A democracia seria, então, representativa de todos - e não da maioria - igual e imparcial, na qual, ao final, prevaleceria a força do argumento e não a força numérica ${ }^{68}$.

Importante salientar, todavia, que esse modelo liberal de representação excluía uma parte considerável de cidadãos, principalmente a classe trabalhadora, cada vez mais oprimida pelo capitalismo, a qual percebeu, assim como a burguesia percebera um século antes, só ser possível a ocorrência de mudanças se participasse do sistema representativo ${ }^{69}$.

É nesse passo, principalmente após a II Guerra Mundial, que a democracia representativa passa a suceder ao governo representativo, e diferentemente deste, não traduz apenas a legitimação dos governantes pelo consentimento dos governados. Há a inserção do

\footnotetext{
${ }^{66}$ FERREIRA FILHO, Manoel Gonçalves. Curso de direito constitucional. cit. p. 82.

${ }^{67}$ Tocqueville explica que nas Colônias dos Estados Unidos a aristocracia nunca foi valorizada, motivo pelo qual a origem sanguínea das pessoas não era considerada para obtenção de poder político. Lá importava o intelecto, pois conhecimento e virtude eram os valores que poderiam ser transmitidos aos filhos. In: TOCQUEVILLE, Alexis de. Democracy in America. Trad. inglesa: Henry Reeve. Hazleton: Pennsylvania State University. p. 65. Disponível em: <http://hn.psu.edu/faculty/jmanis/tocqueville.htm>. Acesso em: $26 \mathrm{dez}$. 2011. Esse pensamento de igualdade entre as pessoas já estava expresso na Declaração de Independência das Colônias: "Nós consideramos essas verdades como evidentes por si, que todos os homens são criados iguais, e são dotados pelo Criador de certos direitos inalienáveis, entre os quais vida, liberdade e busca da felicidade" (traduzi). Disponível em: <http://www.archives.gov/exhibits/charters/declaration_transcript.html>. Acesso em: 2 fev. 2012.

${ }^{68}$ MILL, John Stuart. Considerações sobre o governo representativo. $2^{\mathrm{a}}$ ed. Trad. E. Jacy Monteiro. São Paulo: Ibrasa, 1983. p. 109.

${ }^{69}$ Ao contrário do que se possa pensar, a classe trabalhadora a qual nos referimos não se resume ao proletariado ou ao conjunto de trabalhadores assalariados frabris ou industriais. Essa classe trabalhadora era formada, inclusive, por isso o grande número, por todos os trabalhadores pobres, especialmente, os trabalhadores urbanos, nos quais se incluíam os artífices, os artesãos, os empregados domésticos e outros que trabalhavam da mesma forma que antes da Revolução Industrial, tanto que os primeiros sindicatos eram formados, em sua grande maioria, por impressores, chapeleiros, alfaiates. A exceção era a Grã-Bretanha, onde o proletariado já estava
} 
povo na tomada de decisões, até diretamente (com utilização de referendos e plebiscitos), o que, por um lado, torna patente a diferença ideológica entre os estratos sociais, culminando na necessidade da criação de órgãos aptos a representarem os diversos ideais - os partidos políticos $^{70}$.

Assim, filósofos e cientistas sociais começaram a estudar uma maneira para conciliar o capitalismo liberal burguês com as necessidades sociais da classe operária. Os socialistas Karl Marx e Friedrich Engels foram pensadores importantes do período, pois sua doutrina serviu de inspiração para a criação do partido comunista russo, o qual propiciou a implementação do “socialismo real” pós-revolução de 1917.

Além dos pensadores alemães, outros cientistas foram responsáveis pela disseminação da ideia socialista no mundo, ainda que com visões estratégicas diferentes. São exemplos: Charles Fourier, Claude-Henry de Rouvroy Saint Simon, Pierre-Joseph Proudhon, na França, e Robert Owen, na Inglaterra.

A proposta social-democrática ajudou na transformação do sistema representativo burguês, pois instituiu o sufrágio universal e propiciou o crescimento de partidos de massa para a disputa eleitoral.

Atribuiu-se a origem formal dos partidos políticos ao Reform Act de 1832, na Inglaterra, pois antes disso "tratava-se de simples etiquetas atrás das quais estavam os representantes de um grupo homogêneo, não dividido por conflitos de interesses ou por diferenças ideológicas substanciais, que aderiam a um ou a outro grupo, sobretudo por tradições locais ou familiares" ${ }^{\prime 71}$.

O contraponto que os partidos políticos trazem à democracia representativa é que a escolha do eleitor passa a ser entre programas de governo e não mais entre indivíduos pelas suas qualidades. Há ainda a escolha de homens, porém homens que realizariam o programa de governo, proposto pela agremiação partidária, e eleitos pelo povo ${ }^{72}$.

começando a se organizar e, por vezes, até liderava o grupo de trabalhadores artesãos e empregados domésticos. In: HOBSBAWM, Eric. J. A Era das revoluções: Europa 1789-1848. cit. p. 234-235.

${ }^{70}$ MIRANDA, Jorge. Manual de direito constitucional. cit. p. 367.

${ }^{71}$ OPPO, Ana. Verbete: partidos políticos. In: BOBBIO, Norberto e outros. Dicionário de política. $7^{\mathrm{a}}$ ed. Trad. João Ferreira [et al.]. Brasília: Editora UnB, 1995. p. 899.

${ }^{72}$ FERREIRA FILHO, Manoel Gonçalves. A democracia possível. cit. p. 13. 
Monica Herman Salem Caggiano explica que a representação política ganha nova dimensão após o advento das agremiações partidárias, pois a essas últimas foram reservados papeis importantes no cenário político. Compete aos partidos: "não só o enquadramento dos eleitores/representados como o dos eleitos/representantes, os dois polos da equação que se estabelece no jogo da conquista e do exercício do poder no ambiente das sociedades”. Assim, às agremiações cabe a tarefa de mediar os dois polos, viabilizando o objetivo da representação, qual seja, o equilíbrio social, a fim de garantir suporte ao ideal democrático. Desse modo, os partidos são erigidos ao posto de peça integrante do processo governamental $^{73}$.

Além de simples peça do processo governamental, para muitos a função dos partidos políticos tornou-se fundamental para a manutenção da democracia, pois deles dependem os cidadãos para participar do processo eleitoral. É por isso que, ao longo do século XX, essa relação de dependência entre a democracia e os partidos ficou conhecida como "partitocracia".

Partitocracia significa, de fato, mais que Governo dos partidos, seu domínio ou expansão da ambição de domínio.

$[\ldots]$

Contudo, na própria palavra-definição "Partitocracia" há uma possível crítica implícita que diz justamente respeito à ambição ou até mesmo ao êxito dos partidos em monopolizar não só o poder político como também a própria vida política organizada. A Partitocracia se identifica então, antes de mais nada, com o predomínio dos partidos em todos os setores: político, social e econômico. Caracteriza-se por um constante esforço dos partidos em penetrar em novos e cada vez mais amplos espaços. É então que a Partitocracia é deveras domínio dos $\operatorname{partidos}^{74}$.

\subsection{A representação na atualidade}

Hodiernamente, preconiza-se que a democracia representativa, muito mais que uma necessidade, seja conveniente. Primeiramente, devido à dificuldade de reunir milhares ou milhões de pessoas e, em segundo lugar, porque muitas destas pessoas não estão preparadas para entender os problemas excessivamente técnicos e complexos do Estado Democrático de Direito em que vivemos. Nesse sentido, Mostesquieu já previa que o povo não tinha preparo

\footnotetext{
${ }^{73}$ CAGGIANO, Monica Herman Salem. Sistemas eleitorais. cit. pp. 17-18.

${ }^{74}$ PASQUINO, Gianfranco. Verbete: partitocracia. In: BOBBIO, Norberto e outros. Dicionário de política. cit. pp. 905-906.
} 
para decidir sobre tais problemas, mas tinha discernimento para escolher pessoas capazes de governar em seu nome ${ }^{75}$.

Entre os contemporâneos, Norberto Bobbio também partilha desta opinião, dizendo que "os representantes eleitos pelos cidadãos estariam em melhores condições de avaliar quais seriam os interesses gerais melhor do que os próprios cidadãos, fechados demais na contemplação de seus próprios interesses particulares"76.

Na verdade, nos termos utilizados por Cezar Saldanha Souza Junior, a representação é um "processo de causação circular cumulativa", no qual os eleitores transmitem suas opiniões aos representantes, os quais debatem entre si, a fim de chegar a uma nova opinião ${ }^{77}$.

Nessa mesma linha, Carré de Malberg afirma que o mandato não é uma prisão que vincule os representantes, pois estes emitem o sufrágio de forma independente, de acordo com sua consciência e opiniões pessoais ${ }^{78}$.

Cumpre lembrar, em sentido oposto, a posição de Jean-Jaques Rousseau, para quem “é nula toda a lei que o povo diretamente não ratificar". Para Rousseau, a soberania só pode ser exercida diretamente pelo povo, sob pena dele se tornar escravo do parlamento ${ }^{79}$.

Ademais, outros filósofos, adeptos da democracia semidireta, criticavam a posição de Montesquieu, elevando a importância das legislações referendadas, e propondo, como Duguit: "o povo é mais apto para votar boas leis do que para escolher bons representantes" 80 .

O que se deu no Brasil e em grande parte dos Estados democráticos, no entanto, foi a composição da lição de Montesquieu com a de Rousseau, considerando-se legítimos os sistemas que distinguem soberania - da qual só o povo é titular - de governo - exercido pelos representantes. Tem-se aqui a base do mecanismo democrático-representativo, no qual todos participam do processo político (elemento democrático), e alguns discutem e decidem os

\footnotetext{
75 FERREIRA FILHO, Manoel Gonçalves. Fidelidade Partidária e Voto Distrital. São Paulo: Temas Atuais, 1971. p. 11.

${ }^{76}$ BOBBIO, Norberto. Liberalismo e democracia. São Paulo: Brasiliense, 1997. p. 34.

${ }^{77}$ SOUZA JUNIOR, Cezar Saldanha. A crise da democracia no Brasil. Rio de Janeiro: Forense, 1978.

${ }_{78}^{78}$ MALBERG, Raymond Carré de. Teoría general del Estado. cit. p. 929.

79 ROUSSEAU, Jean-Jaques. Do contrato social. Trad. Lourdes Santos Machado. São Paulo: Nova Cultural, 1987. p. 106-108.

${ }^{80}$ DUGUIT, Pierre Marie Nicolás Léon apud BONAVIDES, Paulo. Ciência política. 17 ed. São Paulo: Malheiros, 2010. p. 307.
} 
negócios políticos (elemento representativo). Daí advém a consagração da eleição como método democrático ${ }^{81}$.

Insta consignar, ademais, que o modelo constitucional brasileiro mesclou a democracia indireta, através da representação, partidos e eleições, com instrumentos de democracia direta, por meio de referendos, plebiscitos e iniciativa popular. Na lição de Joaquim Falcão trata-se da "democracia concomitante": "os modelos de democracia nem são sequenciais nem excedentes, mas complementares e concomitantes. $\mathrm{O}$ ideal político moderno aponta para uma democracia concomitante" $" 82$.

Embora se possa ter o convencimento de que a representatividade é necessária e que, como ensina Manoel Gonçalves Ferreira Filho, "o voto é o método menos ruim de selecionar governantes democráticos" ${ }^{\prime} 83$, o problema, no entanto, reside na identificação do povo, titular do poder, com seus representantes eleitos. Várias notícias e pesquisas de opinião ${ }^{84}$, divulgadas na mídia, denotam a insatisfação dos eleitores com as decisões políticas.

Para que não se pense que esse é um problema exclusivamente brasileiro, Pierre Rosanvallon explica que a democracia é evidentemente um bem político, contudo, após dois séculos permanece inacabada. Até mesmo, em seus locais de origem, onde a democracia (representativa ${ }^{85}$ ) foi afirmada e celebrada (Europa e Estados Unidos), ela permanece incerta e vacilante $^{86}$.

O autor descreve como sintomas desse problema da democracia inacabada, por exemplo, os altos índices de abstenção, a falta de interesse dos cidadãos em se inscreverem

${ }^{81}$ FERREIRA FILHO, Manoel Gonçalves. Idéias para uma nova constituição brasileira. São Paulo: Saraiva, 1987. p. 46.

${ }^{82}$ FALCÃO, Joaquim. Democracia, direito e terceiro setor. $2^{a}$. ed. Rio de Janeiro: Editora FGV, 2006. p. 87.

${ }^{83}$ FERREIRA FILHO, Manoel Gonçalves. A democracia possivel. cit. p. 39.

84 " $85 \%$ (dos entrevistados) consideram a política como uma atividade que só beneficia os próprios políticos, e não o povo". In: CUCOLO, Eduardo. "Maioria dos eleitores não acredita em eleições limpas no Brasil, diz Vox Populi". Fonte: Folha Online. 12 ago. 2008. Disponível em: <http://www1.folha.uol.com.br/folha/brasil/ult96u432588.shtml>. Acesso em: 7 set. 2011.

A avaliação da atual composição do Congresso Nacional, eleita em 2006 e com dois anos e sete meses no poder, piora em relação à verificada em maio deste ano: enquanto $19 \%$ consideravam o desempenho de senadores e deputados ótimo ou bom há quase três meses, essa taxa caiu para 14\% agora, ao mesmo tempo em que a parcela dos que avaliam o desempenho da instituição como ruim ou péssimo subiu de 34\% para $44 \%$ hoje. Para 36\%, o desempenho é regular, ante $41 \%$ observado em maio". In: Piora a avaliação do Congresso Nacional. Fonte: Data Folha. 14 ago. 2009. Disponível em : <http://datafolha.folha.uol.com.br/po/ver_po.php?session=901>. Acesso em: 7 set. 2011.

${ }^{85}$ Embora o autor defina apenas como "democracia", obviamente não se trata da democracia originária da Grécia e sim da democracia representativa, a qual conta com aproximadamente dois séculos de existência.

${ }^{86}$ ROSANVALLON, Pierre. Le peuple introuvable - Historie de la représentation démocratique em France. Paris: Gallimard, 1998. p. 9. 
como eleitores, o distanciamento entre o povo e as elites que governam, gerando um sentimento de abandono social. Para ele, as democracias estão marcadas pela decepção, não carregam seu ideal originário de "poder do povo". É o que classifica como mal-estar dentro da democracia (malaise dans la démocratie) ${ }^{87}$.

Tentando conformar o novo ideal democrático, Robert Dahl lista oito garantias institucionais para que se desenvolva a poliarquia ${ }^{88}$ : liberdade de formar e aderir a organizações; liberdade de expressão; direito de voto; eligibilidade para cargos públicos; direito de líderes políticos disputarem apoio e votos; fontes alternativas de informação; eleições livres e idôneas; instituições para fazer com que as políticas governamentais dependam de eleições e outras manifestações de preferência ${ }^{89}$.

Para Monica Herman S. Caggiano, estes elementos conformam e garantem reponsiviness, ou seja, a atuação dos representantes em consonância com os anseios e expectativas da sociedade ${ }^{90}$. Além disso, há de se ressaltar que os representantes também devem prestar contas de seus atos aos representados: tal ação é conhecida como accountability.

\subsection{Alternativas para o futuro da representação}

A crise no sistema democrático de representação, além de aumentar a introdução de instrumentos de participação direta, fez surgir novas propostas democráticas. Desde as décadas finais do século passado, alguns filósofos, cientistas políticos e juristas vêm elaborando a teoria da democracia deliberativa ${ }^{91}$.

\footnotetext{
${ }^{87}$ Ibid. pp. 9-22.

${ }^{88}$ Robert Dahl prefere utilizar o termo poliarquia em lugar de democracia, pois considera que nenhum país conseguiu desenvolver uma democracia formal, assim, classifica os níveis de democratização da seguinte maneira: 1) Hegemonias fechadas: baixa participação social nas eleições e poucos candidatos em disputa política; 2) Hegemonias inclusivas: grande participação social nas eleições, entretanto poucos candidatos em disputa política;3) Oligarquias competitivas: baixa participação social nas eleições, porém grande variedade de candidatos em disputa política; 4) Sociedades poliárquicas: ampla participação social e vasta gama de candidatos nas eleições. In: DAHL, Robert. A. Poliarquia: participação e oposição. Trad. Celso Mauro Paciornik. São Paulo: Editora da Universidade de São Paulo, 1997. p. 30.

${ }^{89}$ DAHL, Robert. A. Poliarquia: participação e oposição. cit. p. 27.

${ }^{90}$ CAgGianO, Monica Herman Salem. Democracia x constitucionalismo. Um navio à deriva?. 14 jun. 2011. Disponível em: <http://www.cepes.org.br/home/index.php?option=com_content\&view=article\&id=365: democracia-X-constitucionalismo-um-navio-a-deriva-\&catid=35:artigos\&Itemid=55>. Acesso em: 12 out. 2011.

91 A criação do termo democracia deliberativa ou, no original, "deliberative democracy" é atribuída a Joseph Bessette em seu estudo: Deliberative democracy: the majority principle in republican government. In:
} 
Ora, se o poder é o do povo, nada mais justo que ele participe das decisões políticas. Contudo, o modelo representativo, ainda que agregue instrumentos de participação direta, basicamente, limita a ação popular à escolha dos representantes e às parcas consultas populares.

Na verdade, tanto os instrumentos de participação popular quanto os procedimentos da chamada democracia deliberativa podem se encaixar dentro da democracia semidireta, uma vez que em nenhum dos casos se pretende excluir a representação, mas há, sim, o intuito de aumentar a participação dos cidadãos.

Além disso, o modelo representativo reduz a participação ao processo eleitoral, no qual os cidadãos exercem suas escolhas por meio de trocas ou permutas, sem, contudo, haver a discussão de argumentações racionais e elaboradas. Como explica Habermas:

Em última análise o que se exige das pessoas é que não levem em conta nada que
não seja o interesse próprio. Seu meio é a barganha e não o argumento. Seus
instrumentos de persuasão não são reivindicações ou razões, mas ofertas
condicionais de serviço e abstenção. Seja formalmente incorporado num voto ou
num contrato ou simplesmente efetivado de modo informal em condutas sociais, um
resultado estratégico não representa um juízo coletivo da razão, mas uma soma
vetorial num campo de forças ${ }^{92}$.

A proposta deliberativa, sem olvidar, contudo, os procedimentos clássicos da democracia (voto periódico, regra da maioria, separação de poderes), propõe que a soberania popular seja exercida por todos os cidadãos, que participarão ativamente das decisões políticas por meio de fóruns e assembleias de debate.

Tem-se, destarte, um processo baseado em relações dialógicas entre os seus participantes, o qual articula interesses e conflitos com a finalidade de influenciar e alterar as preferências pessoais (ou de um setor específico da sociedade) em busca do bem comum. Os atores sociais, inconformados com as decisões políticas, das quais não podem participar, organizam-se e debatem entre si as melhores soluções para a sociedade civil. Essa "rede de comunicação" entre os sujeitos é o que Habermas chama de esfera civil. O autor não a considera uma instituição ou organização, tampouco um sistema, e assim descreve:

A esfera pública pode ser descrita como uma rede adequada para a comunicação de conteúdos, tomadas de posição e opiniões; nela os fluxos comunicacionais são

GOLDWIN, Robert A. e SHAMBRA, William A. How democratic is the Constitution? Washington DC: American Enterprise Institute, 1980. pp. 102-116.

92 HABERMAS, Jürgen. Três modelos normativos de democracia. In: Lua Nova - Revista de cultura e política n. ${ }^{\circ} 36,1995$. p. 43. Disponível em: <http://www.scielo.br/scielo.php?script=sci_arttext\&pid=S010264451995000200003\&lng=en\&nrm=iso. Acesso em 21 mar. 2013. 
filtrados e sintetizados, a ponto de se condensarem em opiniões públicas enfeixadas em temas específicos. Do mesmo modo que o mundo da vida tomado globalmente, a esfera pública se reproduz através do agir comunicativo, implicando apenas o domínio de uma linguagem natural; ela está em sintonia com a compreensibilidade geral da prática comunicativa cotidiana ${ }^{93}$.

Em suma, a democracia deliberativa habermasiana questiona a prerrogativa estatal da ação política e coloca a sociedade, de forma primordial, na discussão política. Todavia, não necessariamente a sociedade terá um poder político-decisório direto, mas, por meio dos diálogos, trará problematização e oxigenação dos pensamentos a fim de fazer valer o "poder produzido comunicativamente" 94 .

A democracia é o regime que pressupõe a participação de todos no governo, assim, e cada vez mais, as minorias têm exercido um papel ativo na sociedade, o que corrobora o aspecto inclusivo do ambiente democrático. Nesse sentido, as decisões tidas como democráticas só fazem sentido se puderem, de fato, expressar de forma justa o interesse de todas as partes afetadas e não apenas o daquelas que podem exprimir uma maioria numérica ou cultural.

Reside, nesse ponto, o da decisão justa, uma das maiores dificuldades enfrentadas pelo regime democrático atual: como respeitar as minorias adotando-se a regra da escolha pela maioria? E é aqui que se encontra o cerne da teoria deliberativa, pois as decisões só serão tomadas após muito debate entre toda a sociedade, de forma a se obter uma política que, embora decidida pela maior parte dos atores sociais, respeita os direitos de classes desfavorecidas.

\footnotetext{
${ }^{93}$ HABERMAS, Jürgen. Direito e democracia: entre facticidade e validade. Vol. II. Trad. Flávio Beno Siebeneichler. $1^{a}$ ed. reimp. Rio de Janeiro: Tempo Brasileiro, 2011. p. 93. E o autor ainda diferencia a esfera pública "geral" daquela "procedimentalmente regulada": "A formação da opinião, desatrelada das decisões, realiza-se numa rede pública e inclusiva de esferas públicas subculturais que se sobrepõem uma às outras, cujas fronteiras reais, sociais e temporais são fluidas. As estruturas de tal esfera pública pluralista formam-se de modo mais ou menos espontâneo, num quadro garantido pelos direitos humanos. E através das esferas públicas que se organizam no interior de associações movimentam-se os fluxos comunicacionais, em princípio ilimitados, formando os componentes informais da esfera pública geral. Tomados em sua totalidade, eles formam um complexo "selvagem" que não se deixa organizar completamente. Devido a sua estrutura anárquica, a esfera pública geral está muito mais exposta aos efeitos de repressão e de exclusão do poder social - distribuído desigualmente - da violência estrutural e da comunicação sistematicamente distorcida, do que as esferas públicas organizadas do complexo parlamentar, que são reguladas por processos. De outro lado, porém, ela tem a vantagem de ser um meio de comunicação isento de limitações, no qual é possível captar melhor novos problemas, conduzir discursos expressivos de auto-entendimento e articular, de modo mais livre, identidades coletivas e interpretações de necessidades. A formação democrática da opinião e da vontade depende de opiniões públicas informais que idealmente se formam em estruturas de uma esfera pública política não desvirtuada pelo poder. De sua parte, a esfera pública precisa contar com uma base social na qual os direitos iguais dos cidadãos conseguiram eficácia social”. Ibid. pp. 32-33.

${ }^{94}$ Para usar o termo de Habermas. Ibid. p. 24.
} 
Em outras palavras, as minorias participam dos debates da sociedade civil e a decisão não é aquela à qual aderiu a maioria, mas sim uma solução boa para todos, pois as deliberações são feitas até chegar próximo a um denominador comum que atenda a maior parte das reivindicações de toda a população.

Esse modelo democrático implica, portanto, a participação ativa de todos. A democracia discursiva ${ }^{95}$ de Habermas determina que as decisões tomadas no âmbito políticoadministrativo devem ser fundamentadas e justificadas pela sociedade. Há um fluxo de comunicação que parte das redes periféricas da esfera pública, passa aos corpos legislativos e atinge o sistema político, influenciando nas decisões.

Para Joshua Cohen, entretanto, o modelo habermasiano valoriza condições excepcionais de influência, na medida em que as propostas oriundas das deliberações da sociedade - à margem do poder oficial - apenas oferecem quebras ocasionais de poder.

Nesse sentido, o autor propõe a necessidade de implementar algumas condições para que os atores sociais realmente consigam impor sua vontade. A primeira condição é a inclusão de preocupações que não ocupam a agenda normal; a segunda é a deliberação orientada pelos valores políticos fundamentais e a última é criar meios de institucionalização com a finalidade de aumentar a qualidade do discurso da esfera pública informal ${ }^{96}$.

Essas condições levam ao que Cohen chama de "poliarquia diretamente deliberativa", a qual tem por finalidade institucionalizar as soluções de problemas de forma direta pelos cidadãos, e não apenas promover a discussão informal com a eventual possibilidade de influência nas deliberações políticas formais ${ }^{97}$.

É também nessa esteira da institucionalização da esfera pública que Bohman propõe uma melhora qualitativa da teoria habermasiana. Para ele, o poder só será legítimo se oriundo do diálogo entre o público deliberante e as instituições que organizam as deliberações ${ }^{98}$.

\footnotetext{
95 Lembra-se que o autor utiliza tanto o termo deliberativa quanto o discursiva para qualificar sua proposta democrática.

${ }^{96}$ COHEN, Joshua. Reflections on Habermas on democracy. In: Ratio Juris, Vol. 12, n. ${ }^{4}$. Dez 1999. Disponível em: <http://dspace.mit.edu/bitstream/handle/1721.1/5452/Ratio-Juris-Vol12-No4.pdf>. Acesso em: 28 mar. 2013. pp.410-411.

${ }^{97}$ Ibid. p. 411.

98 BOHMAN, James. La democracia deliberativa y sus críticos. In: Metapolítica, México, Vol. 4, n. ${ }^{\circ} 14$. Abr/jun 2000. pp.48-57. Disponível em: <http://espacioagon.blogspot.com.br/2009/02/james-bohman-lademocracia-deliberativa.html>. Acesso em: 28 mar. 2013.
} 
Sendo assim, pode-se concluir que a institucionalização da deliberação pública pode elevá-la, de fato, à categoria de poder político, tornando-a uma forma efetiva e eficaz de controle político. Para tanto, contudo, faz-se necessária a criação de mecanismos institucionais que levem à construção do interesse comum, resultante da deliberação, caracterizada, inicialmente, por conflitos de interesse.

Em apertada síntese, pode-se dizer que a democracia deliberativa pretende a participação ativa, equânime, plural e inclusiva de todos os cidadãos. Não se trata apenas da agregação de preferências políticas, mas sim da alteração dessas preferências por um bem comum maior, e, ainda, com poder decisório efetivo. 


\section{PARTICIPAÇÃO POPULAR NA DEMOCRACIA}

\subsection{Conceito de participação}

Participar significa, dentre outros sentidos, "tomar parte em, compartilhar" "99. Nesse sentido, a participação popular na democracia compreende os atos nos quais a população toma parte na vida política da sociedade.

A participação não está restrita ao ato de votar, uma vez que abrange também todas as ações que possam proporcionar o debate político na comunidade. Giácomo Sani dá alguns exemplos: "a militância num partido político, a participação em manifestações, a contribuição para uma certa agremiação política, a discussão de acontecimentos políticos, a participação num comício ou numa reunião de seção, o apoio a um determinado candidato no decorrer da campanha eleitoral, a pressão exigida sobre um dirigente político, a difusão de informações políticas e por aí além"100.

$\mathrm{O}$ autor, ainda, distingue três aspectos da participação política. O primeiro consiste no ato de tomar parte nas decisões políticas, trabalhando, ativamente, com a finalidade de construir, elaborar, modificar uma decisão política. É apenas um dos aspectos da participação política, é o que chama de "participação em sentido estrito". Há, ainda, a “ativação", na qual o sujeito assume uma posição política, dentro ou fora de uma agremiação partidária, porém sem interferir diretamente na decisão tomada. O último aspecto é denominado "presença", como o próprio nome diz, o sujeito apenas se encontra presente em locais nos quais há ativação ou mesmo participação, contudo, é simplesmente atingido receptiva e passivamente pelas ideias expostas, porém sem qualquer contribuição pessoal ${ }^{101}$.

\subsection{Antecedentes históricos}

Após as atrocidades cometidas durante a Segunda Guerra Mundial, o mundo buscava meios que pudessem evitar tais acontecimentos indesejados. Foi assim que, em 1948, a

\footnotetext{
${ }^{99}$ Fonte: Dicionário Houaiss. Disponível em: <http://houaiss.uol.com.br/busca?palavra=participar >. Acesso em: 5 mar. 2013.

${ }^{100}$ Sani, Giácomo. Verbete: participação política. In: BOBBIO, Norberto e outros. Dicionário de política. cit. p. 888.

${ }^{101}$ Ibid. pp. 888-889.
} 
Organização das Nações Unidas adotou a Declaração Universal dos Direitos Humanos, que proclama $^{102}$ os direitos fundamentais.

A partir de então, os direitos humanos são "internacionalizados", deixando de ser reconhecidos apenas por Constituições de Estados e passando a figurar numa "declaração universal". Como a Segunda Guerra significou a ruptura com os direitos humanos, o pósguerra buscou a reconstrução destes e, ainda, colocou-os como paradigma e referencial à ordem internacional. As atrocidades cometidas durante o holocausto chamaram atenção para a necessidade da proclamação de direitos fundamentais, de forma que, respeitada a soberania estatal, houvesse uma proteção aos indivíduos garantida pela ordem internacional ${ }^{103}$.

Para fins deste estudo, é relevante destacar que o artigo $21^{104}$, da Declaração, consolida a participação política como um dos direitos fundamentais. Assim, o cidadão percebeu que a esfera política está inserida em uma muito mais ampla: a esfera da sociedade em seu conjunto ${ }^{105}$. Além disso, a democracia passou a ser considerada "um meio e instrumento de realização de valores essenciais de convivência humana"106. Como explica Georges Burdeau: "não há poder legítimo além daquele que é instituído pela coletividade que ele rege" 107 .

E, para a consolidação da participação popular e da democracia como valores essenciais, faz-se necessário garantir o direito ao sufrágio, pois ele é que viabiliza a realização democrática. Nas palavras de Monica Herman S. Caggiano:

\footnotetext{
${ }^{102}$ Nas palavras de Dalmo de Abreu Dallari, o termo "proclama” é bem empregado, "pois torna evidente que não há concessão ou reconhecimento de direitos, mas proclamação deles, significando que sua existência independe de qualquer vontade ou formalidade". In: DALLARI, Dalmo de Abreu. Elementos de teoria geral do Estado. São Paulo: Saraiva, 2000. p. 211.

${ }^{103}$ PIOVESAN, Flávia. Direitos humanos e o direito constitucional internacional. São Paulo: Saraiva 2006. pp. 116-117.

${ }^{104}$ Artigo 21: (1) Toda pessoa tem o direito de tomar parte no governo de seu país, diretamente ou através de representantes livremente eleitos. (2) Toda pessoa tem direito à igualdade no acesso ao serviço público do seu país. (3) A vontade do povo será base da autoridade governamental; esta vontade será expressa em eleições periódicas e legítimas, por sufrágio universal, por voto secreto ou processo equivalente que assegura a liberdade do voto. (traduzi). Disponível em: 〈http://www.un.org/en/documents/udhr/>. Acesso em 22 jul. 2011.

${ }^{105}$ BOBBIO, Norberto. Estado, governo, sociedade: para uma teoria geral da política. $2^{\mathrm{a}}$. ed. Trad. Marco Aurélio Nogueira. São Paulo: Paz e Terra, 1986. p. 135.

${ }^{106}$ AFONSO DA SILVA, José. Curso de direito constitucional positivo. $25^{\mathrm{a}}$ ed. rev. e atual. São Paulo: Malheiros, 2005. pp. 125-126.

${ }^{107}$ BURDEAU, Georges. Droit constitutionnel et institutions politiques. $7^{\mathrm{a}}$ ed. Paris: Librairie Générale, 1957. p. 93 (traduzi).
} 
O direito de sufrágio é erigido, hoje, a um dos eminentes direitos relacionados ao homem político, exatamente por lhe propiciar, quer ativa, quer passivamente, a participação no polo epicêntrico das decisões políticas ${ }^{108}$.

Desse modo, tal como todas as constituições de Estados que pretendem ser democráticos ${ }^{109}$, a Constituição da República de 1988 adota esse preceito, e em seu parágrafo único do artigo $1^{\mathrm{o}}$ prevê que "todo poder emana do povo, que o exerce por meio de representantes eleitos ou diretamente, nos termos desta Constituição".

É certo que nas constituições anteriores já havia instrumentos de participação, tais como júri popular, plebiscito, escolha de juízes classistas e instrumentos de controle. No entanto, a partir de 1988, ampliaram-se consideravelmente os mecanismos de participação.

Devido aos problemas decorrentes da representação, e, em busca de uma melhor conformação dos anseios da sociedade, começou a se difundir a ideia da utilização de instrumentos de participação popular, caracterizando, assim, a democracia direta, e, combinada ao elemento representativo, consubstancia o que se chama de democracia semidireta. A Constituição da República Federativa do Brasil de 1988 prevê, em seu art. 14, que a soberania popular será exercida pelo sufrágio universal, pelo voto direto, secreto e com igual valor para todos, e, nos termos da lei, mediante os seguintes instrumentos de participação direta: plebiscito, referendo e iniciativa popular. Além destes instrumentos, há outros no ordenamento jurídico brasileiro vigente, como o orçamento participativo e os conselhos comunitários. E como exemplos de direito comparado cumpre lembrar, ainda, o veto popular e o recall.

Experiências mais recentes, como a Constituição venezuelana de 1999, trazem outros meios (políticos e sociais-econômicos) de participação direta, como a eleição para cargos públicos, consulta popular, assembleia aberta, assembleia dos cidadãos - instrumentos políticos - e, autogestão, co-gestão, cooperativas, caixas de poupança e empresa comunitária

\footnotetext{
${ }^{108}$ CAGGIANO, Monica Herman S. Dos direitos políticos. In: Direito constitucional. Coord. Sônia Yuriko Kanashiro Tanaka. São Paulo: Malheiros, 2009. p. 299.

${ }^{109}$ A Carta das Nações Unidas internacionalizou os direitos humanos. Ao aderir à Carta, que é um tratado multilateral, os Estados-partes reconhecem que os direitos humanos, a que ela faz menção, são objeto de legítima preocupação internacional $\mathrm{e}$, nesta medida, não mais de sua exclusiva jurisdição doméstica. In: BUERGENTHAL apud PIOVESAN, Flávia. Direitos humanos e o direito constitucional internacional. cit. p. 129.
} 
- instrumentos sociais-econômicos. Todavia, como bem ressalta Rubens Beçak, essa experiência sulamericana é muito recente para que possa ser tida como imanente ${ }^{110}$.

Assim, vê-se que a utilização dos instrumentos de democracia participativa busca uma forma de o povo se tornar mais presente na tomada de decisões políticas, aumentando, destarte, a legitimidade da democracia representativa.

\subsection{Direito fundamental à participação}

Antes de discorrer sobre o direito fundamental à participação, convém fazer uma breve distinção dos termos, uma vez que a declaração da ONU fala em "direitos humanos" e a Constituição da República de 1988 utilizou a denominação “direitos fundamentais”.

Para Ingo Wolfgang Sarlet, embora seja comum a utilização de ambos os termos como sinônimos, à expressão direitos humanos se aplica um caráter geral e universal, pois diz respeito a todos os povos em qualquer tempo, já os direitos fundamentais referem-se aos direitos humanos positivados e protegidos sob a égide de uma constituição, assim, o primeiro possui caráter supranacional, ao passo que o segundo não ${ }^{111}$.

Desse modo, tem-se também que a efetivação de cada um deles é diferente. Os direitos fundamentais, conquanto digam respeito à ordem interna, atingem ou, ao menos, estão em melhores condições de atingir um maior grau de efetivação se comparados aos direitos humanos (ordem internacional). É que o direito interno possui instâncias, especialmente as judiciárias, dotadas de maior capacidade de fazer cumprir esses direitos ${ }^{112}$.

Em outras palavras, os direitos humanos são garantias próprias das pessoas, independentemente do local onde vivem, pois são albergados pela ordem internacional e positivados nos tratados e demais instrumentos do Direito Público Internacional. Por sua própria natureza instrumental, não têm as devidas condições para garantir a efetivação de tais direitos. Por outro lado, os direitos fundamentais não se subsumem ao rol dos direitos

\footnotetext{
110 BEÇAK, Rubens. Instrumentos de democracia representativa. Disponível em: <http://www.conpedi.org.br/manaus/arquivos/anais/bh/rubens_becak.pdf>. Acesso em 18.jun.2011.

${ }^{111}$ SARLET, Ingo Wolfgang. A eficácia dos direitos fundamentais. $6^{\mathrm{a}}$ ed. Porto Alegre: Livraria do Advogado, 2006. pp. 35-36.

${ }^{112}$ Ibid. p. 40.
} 
humanos mínimos, uma vez que, positivados constitucionalmente, têm eficácia assegurada pelos tribunais internos.

O texto constitucional de 1988 baseou-se na Declaração Universal dos Direitos Humanos, de 1948, para proclamar os direitos fundamentais protegidos pelo Estado brasileiro. Assim, além do rol de direitos elencados pelo artigo $5^{\circ}$ da Constituição da República de 1988 , logo em seu primeiro artigo, o texto dispõe:

Art. $1^{\circ}$ A República Federativa do Brasil, formada pela união indissolúvel dos Estados e Municípios e do Distrito Federal, constitui-se em Estado Democrático de Direito e tem como fundamentos:

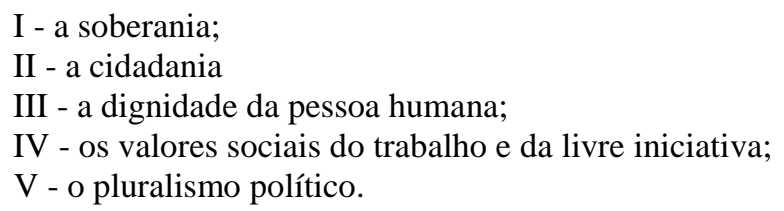

Destaca-se, pois, que a cidadania é um dos fundamentos do Estado brasileiro. Sendo assim, há de se promover a participação ativa dos cidadãos, sem a limitação do voto apenas nos representantes, tudo isso com a finalidade de garantir a própria efetivação do Estado Democrático de Direito.

Desde o seu preâmbulo, a Constituição da República de 1988 já prevê a instituição de um "Estado Democrático, destinado a assegurar o exercício dos direitos sociais e individuais, a liberdade, a segurança, o bem-estar, o desenvolvimento, a igualdade e a justiça como valores supremos de uma sociedade fraterna, pluralista e sem preconceitos, fundada na harmonia social e comprometida, na ordem interna e internacional, com a solução pacífica das controvérsias".

Desse modo, os direitos fundamentais são aqueles protegidos constitucionalmente em razão de sua essencialidade para o homem, individual e coletivamente considerado. É certo que tais direitos variam ao longo do tempo e da história, mas, doutrinariamente, podem ser classificados em gerações, ou dimensões - como preferem alguns doutrinadores - em síntese, para afastar a ideia que uma geração substituiu a outra ${ }^{113}$.

\footnotetext{
${ }^{113}$ Dentre os que defendem a utilização do termo "dimensões", está Ingo Wolfgang Sarlet: "Em que pese o dissídio na esfera terminológica, verifica-se crescente convergência de opiniões no que concerne à ideia que norteia a concepção das três (ou quatro, se assim preferirmos) dimensões dos direitos fundamentais, no sentido de que estes, tendo tido sua trajetória existencial inaugurada com o reconhecimento formal nas primeiras Constituições escritas dos clássicos direitos de matriz liberal-burguesa, se encontram em constante processo de transformação, culminando com a recepção, nos catálogos constitucionais e na seara do Direito Internacional, de múltiplas e diferenciadas posições jurídicas, cujo conteúdo é tão variável quanto as transformações ocorridas na
} 
A primeira dimensão de direitos surgiu após as revoluções liberais, especialmente, a Revolução Francesa. Seu objetivo era a proteção da liberdade individual, principalmente, contra as ingerências do Estado Absoluto. Somente à lei era permitido restringir os direitos, por isso também ficaram conhecidos como liberdades negativas ${ }^{114}$. Em outras palavras, o Estado não poderia agir, senão nos limites legais.

Após a Primeira Guerra Mundial, não era suficiente apenas o amparo dos direitos individuais, era preciso proteger os grupos sociais mais fracos, garantindo-lhes igualdade perante as partes mais fortes da sociedade. Desse modo, surge a segunda dimensão de direitos, visando, inicialmente, superar a exploração da classe operária, ignorada pelo estado liberal ${ }^{115}$, contudo, depois favoreceu outras classes sociais, como mulheres, menores, idosos, consumidores, etc. Os direitos trabalhistas e previdenciários são exemplos dessas garantias, também conhecidas como liberdades positivas, pois o Estado precisava atuar de maneira positiva.

Por fim, após as ações desumanas cometidas na Segunda Guerra, verificou-se a necessidade de defender não apenas classes sociais, mas a própria humanidade e os entes coletivos. Trata-se dos direitos de solidariedade, ou de terceira dimensão, os quais, por meio da internacionalização dos direitos humanos, ganham garantias supranacionais. São exemplos: o direito à paz, ao meio ambiente sadio, etc.

Há doutrinadores que defendem a existência de uma quarta e até uma quinta dimensão de direitos, embora não haja consenso sobre quais são esses direitos. Para Bobbio são aqueles relacionados às pesquisas biológicas e à engenharia genética ${ }^{116}$, contudo, para outros, como Paulo Bonavides, a quarta dimensão relaciona-se com os direitos à democracia, à informação e ao pluralismo, decorrentes da globalização política:

(...) a justiça incorporadora de todas as gerações de direitos fundamentais; da primeira à segunda, da segunda à terceira e desta à quarta, passando pelos direitos civis e políticos, pelos direitos sociais, pelo direito dos povos ao desenvolvimento, até alcançar, com a democracia participativa, onde têm sede os direitos da quarta

realidade social, política, cultural e econômica ao longo dos tempos. Assim sendo, a teoria dimensional dos direitos fundamentais não aponta, tão-somente, para o caráter cumulativo do processo evolutivo e para a natureza complementar de todos os direitos fundamentais, mas afirma, para além disso, sua unidade e indivisibilidade no contexto do direito constitucional interno e, de modo especial, na esfera do moderno 'Direito Internacional dos Direitos Humanos”. Ibid. p. 55.

114 BARROS, Sergio Resende de. Noções sobre gerações de direitos. Disponível em: <http://www.srbarros.com.br/pt/nocoes-sobre-geracoes-de-direitos.cont. >. Acesso em: 16 jan. 2013.

${ }^{115}$ Ibid.

${ }^{116}$ BOBBIO, Norberto. A era dos direitos. Trad. Carlos Nelson Coutinho. 9a ed. Rio de Janeiro: Campus, 1992. p. 6. 
geração - sobretudo o direito à democracia - um paradigma de juridicidade compendiando na dignidade da pessoa humana ${ }^{117}$.

Nesse mesmo sentido, José Afonso da Silva assevera que o sentido moderno da democracia não é propriamente um valor fim, mas um processo inacabado de luta, mais do que isso, é um instrumento "de realização de valores essenciais de convivência humana que se traduzem basicamente nos direitos fundamentais do Homem". A democracia, portanto, é um processo por meio do qual o povo, no decorrer da História, vai afirmando e consolidando a garantia dos direitos fundamentais ${ }^{118}$.

Dessa maneira, se a democracia é o governo do povo, nada mais natural que o povo participe do processo democrático decisório, motivo pelo qual a própria participação democrática também se constituiu em direito fundamental tanto em forma quanto em essência, pois "antes de ser um direito fundamental, é um direito fundante, ou seja, um direito do qual decorre a própria significação dos modos de vida e convivência pelos quais optamos"119.

O direito fundamental à participação é, portanto, a concretização da própria democracia, na medida em que promove o equilíbrio entre a representatividade e a participação do povo soberano e permite a realização do Estado Democrático de Direito.

\subsection{Instrumentos de democracia participativa}

Atualmente, com a concepção moderna de participação popular democrática, vêm sendo empregados e desenvolvidos vários institutos que propiciam uma intervenção direta do eleitorado nos rumos das nações. Os mais tradicionais, no entanto, são: referendo, plebiscito, iniciativa popular, veto e revogação.

\footnotetext{
${ }^{117}$ BONAVIDES, Paulo. Teoria constitucional da democracia participativa - por um direito constitucional de luta e resistência, por uma nova hermenêutica, por uma repolitização da legitimidade. $2^{\mathrm{a}}$ ed. São Paulo: Malheiros, 2003. p. 28.

${ }^{118}$ AFONSO DA SILVA, José. Poder constituinte e poder popular - estudos sobre a constituição. São Paulo: Malheiros, 2002. p. 43.

${ }^{119}$ CUNHA FILHO, Francisco Humberto. A Participação popular na formação da vontade do Estado: um direito fundamental. In: GUERRA FILHO, Willis Santiago (Coor..). Dos direitos humanos aos direitos fundamentais. Porto Alegre: Livraria do Advogado, 1997. pp. 91-92.
} 
Referendo e plebiscito, objetos desse estudo, serão analisados minuciosamente mais à frente. Todavia, de forma introdutória, pode-se dizer que são consultas populares com a finalidade de aprovar ou rejeitar uma norma (referendo) ou saber a opinião sobre temas relativos à condução do governo (plebiscito).

\section{Iniciativa popular}

A iniciativa popular confere aos cidadãos o direito de propor ao legislativo a elaboração de leis ou emendas constitucionais de interesse geral.

O instituto tem origem norte-americana, no final do século XIX, legalmente prevista na Dakota do Sul, mas adotada, de fato, pela primeira vez no Oregon. Passou também pela Constituição de Weimar e na Lei Fundamental de Bonn, nos casos de modificação do território das laender - unidades federativas alemãs ${ }^{120}$.

Nos Estados Unidos, ela se subdivide em duas espécies: a iniciativa direta - através da qual o projeto de lei ou de emenda, subscrito por um número mínimo de eleitores, deve ser submetido à consulta geral nas próximas eleições - e a iniciativa indireta - pela qual a proposta é apresentada ao Legislativo estadual e, somente se não aprovado por este, será submetido à apreciação popular ${ }^{121}$.

Paulo Bonavides aponta, ainda, duas classificações: iniciativa formulada e iniciativa não formulada. Pela iniciativa não formulada ou simples, adotada na Suíça, o povo apresenta apenas um esboço com os traços gerais do projeto legislativo, cabendo à Assembleia discutir e formular o projeto final. Por sua vez, a iniciativa formulada leva ao órgão legislativo um projeto pronto para ser discutido e votado. Em ambos os casos, quando da rejeição pelo Legislativo, geralmente os projetos são postos à consulta popular referendária, de modo que a lei seja a vontade soberana do povo, ainda que contra a resistência política enfrentada nas casas legislativas $^{122}$.

Para Luiz Henrique Boselli de Souza, a iniciativa popular cumpre, ainda, o papel de suprir omissões normativas e garantir plena eficácia dos dispositivos constitucionais, pois,

\footnotetext{
${ }^{120}$ BONAVIDES, Paulo. Ciência política. cit. p. 313.

${ }^{121}$ DALLARI, Dalmo de Abreu. Elementos de teoria geral. cit. p. 154.

${ }^{122}$ BONAVIDES, Paulo. Ciência política. cit. p. 312.
} 
uma vez inerte o Parlamento, surge a prerrogativa popular para exercer diretamente essa soberania $^{123}$.

A vantagem desse mecanismo de participação direta é justamente o exercício da soberania popular no tocante as leis às quais o povo se submete. No referendo e no veto a manifestação é apenas negativa, ou seja, o povo se mostra contrário a uma lei já imposta, de outro lado, pela iniciativa popular verifica-se uma manifestação positiva, a população, por si, invoca as normas que deverá seguir.

A Constituição da República de 1988 previu a iniciativa popular legislativa no inciso III do art. 14, sendo que os requisitos formais para a efetivação da proposta estão dispostos no parágrafo $2^{\circ}$ do art. 61: “A iniciativa popular pode ser exercida pela apresentação à Câmara dos Deputados de projeto de lei subscrito por, no mínimo, um por cento do eleitorado nacional, distribuído pelo menos por cinco Estados, com não menos de três décimos por cento dos eleitores de cada um deles".

Outras disposições sobre a iniciativa popular estão presentes na Lei n. ${ }^{\circ}$ 9.709/98, tais como: o projeto de iniciativa deverá abordar apenas um assunto (art. $13, \S 1^{\circ}$ ), caso haja vício de forma, a Câmara dos Deputados deverá saná-lo (art. 13, § $2^{\circ}$ ) dando seguimento conforme disposto no Regimento Interno da Casa (art. 14).

Dessa maneira, percebe-se que o legislador nacional adotou a iniciativa formulada, uma vez que pressupõe a apresentação de um projeto de lei pronto para ser discutido e votado.

No tocante ao número de eleitores aptos a subscreverem a proposta de iniciativa popular - um por cento do eleitorado nacional, equivalente a aproximadamente $1.378 .824^{124}$ à primeira vista parece elevado, se comparado às cem mil ou cinquenta mil assinaturas exigidas na Suíça e na Itália, respectivamente. Contudo, na prática, observa-se que o constituinte brasileiro não foi nem tão liberal nem tão conservador. A Itália, por exemplo, possibilita que cinquenta mil eleitores apresentem projeto de iniciativa popular (art. $71,2^{\mathrm{a}}$

\footnotetext{
123 SOUZA, Luiz Henrique Boselli de. A correlação da efetividade das normas constitucionais com o suprimento das omissões normativas. Tese de Doutorado, sob orientação do Professor Doutor Sérgio Resende de Barros, apresentada na Faculdade de Direito da Universidade de São Paulo, 2010. p 170.

${ }^{124}$ Um por cento do eleitorado nacional em março de 2012. Fonte: Tribunal Superior Eleitoral. Disponível em: <http://www.tse.jus.br/eleicoes/estatisticas-do-eleitorado/estatisticas-do-eleitorado/evolucao-do-eleitorado>.

Acesso em: 16 abr. 2012.
} 
parte, da Constituição italiana ${ }^{125}$ ), o que representa menos de $0,1 \%$ do eleitorado ${ }^{126}$. Já o modelo de participação popular suíço exige a manifestação de aproximadamente $1,95 \%$ do eleitorado ${ }^{127}$ para a subscrição de iniciativa popular geral.

Há de se ressaltar que todas as condições impostas pelo constituinte brasileiro, para formulação de iniciativa popular, sofreram pesadas críticas da doutrina. Manoel Gonçalves Ferreira Filho leciona que: "as exigências, que, no texto em exame condicionam a propositura popular de leis, tornam difícil, portanto, improvável, que tal ocorra efetivamente"128, tornando-se um "instituto decorativo" "29 . Sérgio Resende de Barros costuma dizer que o que o legislador constitucional dá com uma das mãos, e tira com a outra. Para o professor é mais fácil conseguir o início de tramitação de um projeto fazendo pressão direta sobre um deputado do que cumprindo os requisitos impostos pela Constituição da República de $1988^{130}$.

De outro lado, há de se considerar que as exigências para a realização da iniciativa popular não podem ser tamanhas a ponto de impossibilitar o exercício do instituto e nem irrisórias que o levassem ao descrédito. Desse modo, há quem entenda que tais requisitos podem ser encarados com efeitos mobilizadores e conscientizadores, na medida em que ampliarão às massas sociais o debate sobre questões de interesse público ${ }^{131}$.

Ainda a exigência de distribuir as assinaturas por, pelo menos, cinco estados da federação, constitui garantia ao pacto federativo, na medida em que evita que a iniciativa popular parta de setores localizados da sociedade, visando à consecução de interesses particulares ou regionalizados.

\footnotetext{
${ }^{125}$ Constituição italiana - art. 71, segunda parte - O povo exercita a iniciativa de lei, mediante a proposta, de pelo menos cinquenta mil eleitores, de um projeto redigido em artigos. (traduzi). Disponível em: <http://www.governo.it/Governo/Costituzione/2_titolo1.html>. Acesso em: 12 abr. 2012.

${ }^{126}$ Total do eleitorado italiano no Referendo de 12 jun. 2011: 50.417 .952 eleitores. Fonte: Governo italiano Ministero dell'Interno. Disponível em: <http://elezionistorico.interno.itindex.php? tpel=F\&dtel=12/06/2011\&tpa=Y\&tpe=A\&lev0=0\&levsut $0=0 \&$ es $0=S \& m s=S>$. Acesso em 16 abr. 2012.

${ }^{127}$ Constituição suíça - art. 139 a - Iniciativa populbid.lar geral: 1100000 pessoas com direito de votar podem, no prazo de 18 meses, contado a partir da publicação oficial de sua iniciativa, na forma de uma sugestão geral, solicitar a aprovação, alteração ou anulação de prescrições da Constituição ou de leis. [...]. (traduzi). Disponível em: <http://www.admin.ch/ch/f/rs/101/index.html>. Acesso em: 10 abr. 2012. Esses cem mil eleitores correspondem a aproximadamente 1,95\% do eleitorado de 5.124.034, em 2011. Fonte: Governo suíço. Disponível em: <http://www.bfs.admin.ch/bfs/portal/fr/index/themen/17/02/blank/key/national_rat/ wahlbeteiligung.html>. Acesso em: 16 abr. 2012.

${ }^{128}$ FERREIRA FILHO, Manoel Gonçalves. Comentários à Constituição Brasileira de 1988. Vol. 2. São Paulo: Saraiva, 1992. p. 98.

${ }_{129}$ FERREIRA FILHO, Manoel Gonçalves. Do processo legislativo. São Paulo: Saraiva, 2001. p. 207.

${ }^{130}$ BARROS, Sérgio Resende de. Informação verbal in: aulas da Graduação em Direito da Universidade de São Paulo, 2010.

${ }^{131}$ DALLARI, Dalmo de Abreu. A participação popular e suas conquistas. In: Cidadão constituinte: a saga das emendas populares. Rio de Janeiro: Paz e Terra, 1989. p. 378.
} 
Por outro lado, a necessidade de cumprir tantos requisitos afasta a maioria dos eleitores da iniciativa popular e, na prática, acabará se tornando viável apenas com a ajuda dos setores organizados da sociedade ${ }^{132}$, como organizações sociais, sindicatos e grupos econômicos.

A experiência democrática brasileira encontra, de fato, poucas leis oriundas da iniciativa popular. A primeira delas foi a Lei n. ${ }^{\circ}$ 8.930/1994 que alterou a Lei n. ${ }^{\circ}$ 8.072/1990, dos crimes hediondos, para incluir no rol de tais delitos, os homicídios qualificados e os cometidos por grupos de extermínio. Na exposição de motivos cita-se o aumento da violência nos grandes centros urbanos e a necessidade de coibi-la, especialmente dos homicídios causados por motivos torpes ${ }^{133}$. Em verdade esse projeto foi apoiado pela autora de novelas Glória Perez, após o homicídio (por motivo torpe) de sua filha. O fato causou grande comoção nacional e recebeu apoio de grandes setores sociais, principalmente da mídia, o que viabilizou a coleta das assinaturas.

Outra lei resultante de iniciativa popular foi a Lei n. ${ }^{\circ}$ 9.840/1999 que modificou legislações anteriores para permitir o indeferimento do registro de candidatura ou cassação do diploma daqueles que comprovadamente incorreram na captação ilícita de sufrágio. Esse projeto de iniciativa popular obteve o apoio da Comissão Brasileira Justiça e Paz, da Conferência Nacional dos Bispos do Brasil - CNBB, dando continuidade à Campanha da Fraternidade de 1996, cujo tema foi "Fraternidade e Política".

A última norma aprovada foi a Lei Complementar n. ${ }^{\circ}$ 135/2010, conhecida como "lei da ficha limpa", pois institui novos casos de inelegibilidade, mesmo que não haja o trânsito em julgado, conquanto exista decisão de órgão colegiado. Referida lei, já declarada constitucional pelo Supremo Tribunal Federal, pretende acabar com a brecha gerada pelos intermináveis recursos que jamais possibilitavam a cassação de mandatos. Também esse projeto recebeu apoio de uma entidade de expressão: a organização da sociedade civil "Movimento de Combate à Corrupção Eleitoral" - MCCE, apoiada também pela CNBB.

Constata-se, desse modo, ainda que não se trate, como disse Manoel Gonçalves Ferreira Filho, de "instituto decorativo", que o mesmo tem pouca efetividade. Verificando-se,

\footnotetext{
${ }^{132}$ MOISÉS, José Álvaro. Cidadania e participação: ensaio sobre o plebiscito, referendo e a iniciativa popular na nova Constituição. São Paulo: Marco Zero, 1990. p. 87.

133 In: Diário do Congresso Nacional (Seção I), out. 1993. p. 21817. Disponível em: 〈http://imagem.camara.gov.br/montaPdf.asp?narquivo=DCD12OUT1993.pdf\&npagina=35>. Acesso em: 16abr. 2012.
} 
na prática, que logrou êxito apenas quando apoiado por setores organizados da sociedade civil.

Outro aspecto da iniciativa popular é obrigatoriedade do Parlamento debater o projeto levado a ele pela parcela competente do eleitorado. No Brasil, após a apresentação do projeto, este tramitará, segundo as regras do Regimento Interno das casas do Congresso, da mesma maneira que as leis propostas perante a Câmara dos Deputados. Assim, não há qualquer instrumento, como por exemplo um referendo posterior, que possa garantir a vontade popular, caso o projeto seja arquivado ou sofra alterações.

Destarte, observa-se que o Brasil adotou postura semelhante à Itália. Lá, a iniciativa popular trata apenas de uma moção do povo, sendo que a este cabe apenas o poder de levar um projeto aos seus representantes, pois a elaboração das leis é tarefa privativa do Legislativo, que escolherá se seguirá, ou não, com o debate ${ }^{134}$.

Contudo, a prática norte-americana (tanto na iniciativa direta quanto na indireta) e também a suíça levam a intervenções mais categóricas por parte dos cidadãos. A Constituição helvética prevê que, após a apresentação do projeto de iniciativa popular, se o Conselho Federal não concordar, deve submeter um projeto substitutivo a referendo popular, que, caso aprovado, será efetivado ainda que à sua revelia ${ }^{135}$. Nota-se que há instrumentos de apoio à efetivação da iniciativa, nesse caso, o referendo.

No concernente às matérias que serão objetos de iniciativa popular, a Constituição da República de 1988 não foi expressa. Dessa maneira, por meio da hermenêutica, conclui-se que poderá tratar de todas as matérias previstas para leis complementares ou ordinárias, excluídas as de competência privativa.

Não há, portanto, a possibilidade de iniciativa popular para emendas constitucionais, o que restringe consideravelmente alguns anseios da população. Nesse sentido, assevera José Álvaro Moisés:

\footnotetext{
${ }^{134}$ Constituição italiana - art. 71, segunda parte - O povo exercita a iniciativa de lei, mediante a proposta, de pelo menos cinquenta mil eleitores, de um projeto redigido em artigos. (traduzi). Disponível em: <http://www.governo.it/Governo/Costituzione/2_titolo1.html>. Acesso em: 12 abr. 2012.

${ }_{135}$ Constituição suíça - art. 139 a. Disponível em: <http://www.admin.ch/ch/f/rs/101/index.html>. Acesso em: 12 abr. 2012.
} 
“(...) essa impossibilidade restringe a eficácia do princípio da soberania popular, uma vez que a participação, ademais das eleições, só intervém para produzir efeitos no plano da legislação ordinária (o que, certamente, não é irrelevante)" ${ }^{\text {"136 }}$.

Malgrado o texto constitucional, em nível federal, somente tenha previsto a iniciativa popular legislativa, foi genérico quanto aos Estados (art. 27, § $4^{\circ}$ ), abrindo margem aos constituintes estaduais que inserissem a iniciativa popular constitucional. Já em nível municipal, o texto atribuiu o percentual de, ao menos, cinco por cento do eleitorado para propor iniciativa popular (art. 29, XIII).

Destacam-se as unidades federativas que possibilitam à população a utilização de iniciativa popular para propor emendas constitucionais: Acre (art. 53, § 5 ); Alagoas (art. 85, IV); Amapá (art. 95, XIII); Amazonas (art. 28, XIX); Bahia (art. 71, XXI); Ceará (art. 49, I); Espírito Santo (art. 56, XVII); Goiás (art. 11, XI); Mato Grosso (art. 26, XII); Minas Gerais (art. 32, XXXVIII); Pará (art. 92, XII); Paraíba (art. 54, XX); Paraná (art. 54, XXI); Pernambuco (art. 14, XXV); Piauí (art. 63, XII); Rio de Janeiro (art. 98, XXI); Rio Grande do Norte (art. 35, XII); Rio Grande do Sul (art. 53, XI); Rondônia (art. 29, XXVIII); Santa Catarina (art. 40, II); São Paulo (Art. 20, XVIII); Sergipe (art. 47, XX); e Tocantins (art. 19, XXI).

\section{Veto popular}

O veto popular confere ao povo o direito de opinar se determinada lei, já discutida e aprovada pelo Legislativo, será vigente ou não. Após a promulgação, é concedido um prazo para determinado número de eleitores se manifestarem. Caso não o façam, a lei é considerada aprovada. Todavia, se o corpo eleitoral pede a consulta e veta a lei, esta perde seus efeitos de maneira retroativa. Sendo assim, há de se considerar o "caráter incidental" desse instituto ${ }^{137}$.

Há quem considere o veto uma forma de referendo ${ }^{138}$. Dalmo de Abreu Dallari acrescenta que esse instituto é conhecido nos Estados Unidos por mandatory referendum ${ }^{139}$. Na Suíça, embora não haja mais previsão expressa de veto popular, como houvera em fins do

\footnotetext{
${ }^{136}$ MOISÉS, José Álvaro. Cidadania e participação: ensaio sobre o plebiscito, referendo e a iniciativa popular na nova Constituição. cit. p. 84.

${ }^{137}$ ARDANT, Philippe. Institutions politiques et droit constitucionnel. Paris: Librairie générale de droit et de jurisprudence, 1991. p. 178.

${ }_{138}$ DUVERGER, Maurice e SANTI ROMANO apud BONAVIDES, Paulo. Ciência política. cit. p. 316.
} 
século $\mathrm{XIX}^{140}$, o chamado referendo facultativo do art. 141, da Constituição suíça, nada mais é que o veto, uma vez que possibilita a cinquenta mil cidadãos ou oito cantões, no prazo de cem dias após a publicação, referendarem, ou não, uma lei federal já em vigor ${ }^{141}$.

Georges Burdeau, todavia, enfatiza a distinção entre veto e referendo afirmando que o veto é um processo interventivo muito mais enérgico que o referendo, pois, no caso do primeiro, a lei já está acabada, pronta para produzir efeitos, e assim o fará, caso não haja manifestação, diferentemente, portanto, do referendo, que tem por objeto apenas um projeto de $l e i^{142}$.

Nesse diapasão, posiciona-se Maria Benedita Malaquias Pires Urbano:

[...] o significado das duas figuras é diferente, apresentando-se o grau de intervenção popular mais acentuado no caso da consulta referendária. Através do referendo o povo intervém, em maior ou menor escala consoante o tipo de referendo, na feitura dos atos normativos, sendo a sua participação, quando seja obrigatória ou quando, sendo facultativa, seja solicitada, necessária para a perfeição jurídica desse ato. A sua utilização pelo povo faculta a este a possibilidade de sancionar (aceitar ou rejeitar) um ato normativo que ainda não é perfeito (excetua-se obviamente o referendo de tipo abrogativo, que recai sobre leis que já estão em vigor, embora, como vimos, não coincida totalmente com a figura do veto popular), tornando-se deste modo co-legislador. Mediante a utilização do veto, o povo limita-se a por em prática uma faculdade de empêcher sobre uma lei que já é perfeita e que por conseguinte constituiu uma obra exclusiva dos órgãos representativos, não exercendo o povo, portanto, qualquer papel criativo ${ }^{143}$.

Destarte, nota-se ser o veto popular um instrumento corretivo para os desvios da representação $^{144}$, pois, dada a insatisfação do corpo eleitoral com uma lei, este pode vetá-la, fazendo valer a máxima titularidade do poder popular. A vontade dos cidadãos deve prevalecer à dos representantes, e esse instrumento preserva ainda os direitos das minorias, pois ela, que não elegera tais representantes, terá o direito de invocar a intervenção, quando se julgar aviltada em seus anseios.

\footnotetext{
${ }^{139}$ DALLARI, Dalmo de Abreu. Elementos de teoria geral. cit. p. 154.

${ }^{140}$ BATTELLI, Maurice. Les institutions de démocratie directe en droit suisse et comparé moderne. Paris: Sirey, 1932. p. 5.

${ }^{141}$ Constituição suíça - art. 141 - Referendo facultativo: 1 Se 50000 pessoas com direito de votar ou oito cantões o solicitam, no prazo de 100 dias desde a publicação oficial do decreto, devem ser submetidas ao povo para ser votados (...) a. as leis federais; [...]. (traduzi). Disponível em: <http://www.admin.ch/ch/f/rs/101/index.html>. Acesso em: 10 abr. 2012.

${ }_{142}$ BURDEAU, G. apud BONAVIDES, Paulo. Ciência política. cit. p. 316.

143 URBANO, Maria Benedita Malaquias Pires. O referendo. Perfil histórico-evolutivo do instituto. Configuração jurídica do referendo em Portugal. Coimbra: Coimbra Editora, 1998. pp. 78-79.

${ }^{144}$ SILVA, Daniela Romanelli da. Democracia e direitos políticos. Campinas: Instituto de direitos políticos, 2005. p. 191.
} 
De outro lado, o veto popular pode implicar um possível desprestígio dos representantes, os quais terão o constrangimento de ter uma norma, por eles aprovada, rejeitada pelo povo. Ademais, há de se considerar que certas leis, por conterem objetos impopulares - por exemplo, leis que criem ou aumentem tributos -, poderão ter dificuldades para vigorarem se contra elas for invocado o veto.

Por fim, cumpre lembrar que o veto popular quase foi adotado na Constituição da República de 1988. Estava previsto no inciso IV, do art. 14, do Anteprojeto, e, embora tenha sido aprovado em primeiro turno de votação, não obteve o mesmo êxito no segundo, tendo sido, pois, abandonado ${ }^{145}$.

\section{$\underline{\text { Revogação }}$}

Outro mecanismo utilizado pelas democracias semidiretas é a revogação, por meio da qual o povo pode por fim ao mandato de um funcionário ou parlamentar antes da expiração do prazo legal. São conhecidas duas formas de revogação: o recall e o abberufungsrecht.

O abberufungsrecht é admitido em alguns cantões suíços e consiste na revogação coletiva dos mandatos de todos os parlamentares. Sua aplicação se dá quando há a perda de confiança em toda a Assembleia, permitindo a determinado número de eleitores - definido constitucionalmente - destituir o Parlamento por completo ${ }^{146}$.

Já o recall é típico do direito norte-americano, adotado nas esferas municipais e estaduais, permitindo a certa parcela do eleitorado, em geral, dez por cento, requerer a cassação do mandato do parlamentar ou magistrado que perdeu a credibilidade, determinando que seja substituído ou demitido.

Por vezes, a própria cédula de votação traz a defesa do parlamentar e, na mesma ocasião, pode se dar a disputa com pretensos substitutos. Caso o mandato não seja revogado e nenhum candidato à substituição eleito, considera-se eleito o “demandado" para novo período.

\footnotetext{
${ }^{145}$ Cf. Ata da $318^{\text {a }}$ Sessão, em 16 de agosto de 1988. Publicado em Diário da Assembleia Nacional Constituinte. Número 293. Brasília, 17 de agosto de 1988. p. 419. Disponível em: <http://www2.camara.gov.br/atividadelegislativa/legislacao/Constituicoes_Brasileiras/constituicao-cidada/publicacoes/anais-da-assembleia-nacionalconstituinte>. Acesso em: 28 fev. 2012.

${ }^{146}$ BONAVIDES, Paulo. Ciência política. cit. p. 315-316.
} 
A outra forma de recall existente nos Estados Unidos é o judicial, aplicável tanto aos juízes quanto às decisões judiciais. A revogação dos cargos dos magistrados se opera de maneira semelhante à dos parlamentares. Todavia, sofre muita crítica dos que a consideram uma forma de intervenção na independência do Judiciário, deixando esse órgão à mercê de manobras políticas.

O recall das decisões judiciais foi preconizado por Theodore Roosevelt, em 1912, consistindo na cassação, pela maioria de eleitores, das decisões declaratórias de inconstitucionalidade de alguma lei, à exceção das decisões da Suprema Corte ${ }^{147}$. Esse mecanismo é pertinente, especialmente, nos estados que elegem seus magistrados e esses ficam expostos à pressão dos grupos econômicos que o apoiaram em detrimento às leis sociais, por vezes, fruto até da iniciativa popular.

A Constituição de Weimar previa a possibilidade da convocação do povo pelo Reichstag a fim de confirmar ou destituir do cargo o presidente do Reich. A Constituição da antiga União Soviética também previa a possibilidade de revogação do mandato dos representantes da classe trabalhadora ${ }^{148}$.

Esse instituto da revogação de mandatos nunca foi previsto pelas constituições nacionais ou federais brasileiras. Nos tempos do Império, embora não houvesse democracia, havia algo semelhante ao recall, pois os membros do Conselho de Procuradores poderiam ser substituídos caso não desempenhassem sua função a contento ${ }^{149}$.

Após a proclamação da República, a exemplo de outros estados da federação, como Santa Catarina, Rio Grande do Sul e Goiás, a Constituição paulista de $1891^{150}$ previu a possibilidade de cassação do mandato de representantes, nos seguintes termos:

Art. 6.

$\S 3 .^{\circ}$ Poderá, entretanto, ser a qualquer tempo cassado o mandato legislativo, mediante consulta feita ao eleitorado por proposta de um terço dos eleitores e na

\footnotetext{
${ }^{147}$ DALLARI, Dalmo de Abreu. Elementos de teoria geral. cit. p. 155.

${ }^{148}$ BONAVIDES, Paulo. Ciência política. cit. p. 314.

149 BENEVIDES, Maria Victoria de Mesquita. A cidadania ativa: referendo, plebiscito e iniciativa popular. $2^{\mathrm{a}}$ ed. São Paulo: Ática, 1991. p. 112.

150 Fonte: Assembleia Legislativa de São Paulo. Disponível em: <http://www.al.sp.gov.br/portal/site /Internet/menuitem.a5cf20fe598dde2eca76e110f20041ca/?vgnextoid=81d950d649467110VgnVCM1000005900 14acRCRD>. Acesso em: 25 abr. 2012.
} 
qual o representante não obtenha a seu favor metade e mais um, pelo menos, dos sufrágios com que houver sido eleito.

Verifica-se, destarte, que a legislação paulista dispunha que os próprios eleitores, quando insatisfeitos, poderiam propor a consulta sobre a continuidade, ou não, dos mandatos de seus representantes.

Entretanto, o instituto nunca foi utilizado na prática. Auro Augusto Caliman atribui esse fato ao bom desempenho dos parlamentares, ou, sobretudo, pela dificuldade na colheita das assinaturas necessárias à propositura. Não se olvide a precariedade dos meios de comunicação da época e o domínio do "coronelismo" na política ${ }^{151}$.

A utilização desse instrumento tem grande importância na correção da superveniente falta de legitimidade dos representantes eleitos. Comparando-se ao direito privado, por exemplo, quando um mandante outorga poderes a um mandatário, caso esse último não cumpra suas funções a contento, o instrumento pode ser revogado. Na esfera pública há o recall, pois a requerimento de certa quantidade de eleitores, é consultado todo o eleitorado interessado, podendo haver a cassação do mandato daquele representante que não estiver satisfazendo os anseios daqueles que o elegeram.

A Constituição da República de 1988 até prevê um instrumento de cassação de mandatos, o impedimento, ou impeachment, do presidente da república, quando cometa infrações político-administrativas, os chamados crimes de responsabilidade (art. 86, $1^{\mathrm{a}}$ parte). Porém, o impeachment é muito menos eficaz, do ponto de vista da amplitude democrática, do que o recall, uma vez que necessita de motivação - a prática de crime de responsabilidade - e a iniciativa para requerer o processo é de dois terços da Câmara dos Deputados.

Cumpre ressaltar que, em consequência da campanha nacional em defesa da República e da democracia, lançada pela Ordem dos Advogados do Brasil, foi requerida, por essa instituição, a introdução do recall no ordenamento jurídico brasileiro. Transformada na Proposta de Emenda à Constituição n. ${ }^{\circ} 73 / 2005$, em trâmite no Senado, prevê o acréscimo do art. 14-A à Constituição ${ }^{152}$.

\footnotetext{
${ }^{151}$ CALIMAN, Auro Augusto. O recall no Estado de São Paulo. In: Revista de Informação Legislativa. Ano 42, n. ${ }^{\circ}$ 165. Jan/mar 2005. p. 201.

152 Proposta de Emenda à Constituição n. $73 / 2005$ : Art. 14-A Transcorrido um ano da data da posse nos respectivos cargos, o Presidente da República, ou os membros do Congresso Nacional, poderão ter seus mandatos revogados por referendo popular, na forma do disposto nos parágrafos seguintes.
} 
Desse modo, após um ano da posse, o Presidente da República, ou os membros do Congresso Nacional, poderão ter seus mandatos revogados por referendo popular, sendo que os senadores serão destituídos pelo eleitorado do estado ao qual pertencem.

Nota-se, além disso, que o projeto prevê a cassação coletiva dos mandatos de todos os membros da Câmara dos Deputados, e determinação de nova eleição, assemelhando-se ao abberufungsrecht suíço. E, no silêncio da proposta quanto à nova eleição para os cargos majoritários, entende-se que serão empossados, no lugar daquele que tiver o mandato cassado, seu vice ou suplente.

O quórum da iniciativa popular, dirigida ao Tribunal Superior Eleitoral, para a convocação do referendo para revogação dos mandatos é de dois por cento do eleitorado nacional (ou estadual), distribuído pelo menos por sete Estados (ou Municípios), com não menos de cinco décimos por cento em cada um deles. Ainda, para a revogação do cargo de Presidente, o referendo poderá ser requerido, inclusive, por iniciativa da maioria absoluta dos membros do Congresso Nacional.

Por fim, a proposta impõe um limite às consultas, uma vez que havendo resultado contrário à revogação, não poderá ser requerido novo referendo até a expiração do mandato ou o fim da legislatura.

A justificativa da proposta é a possibilidade do povo, titular do poder, manter a relação de confiança com seus representantes. Não é uma forma de implantação do mandato

\footnotetext{
$\S 1^{\circ} \mathrm{O}$ mandato de senador poderá ser revogado pelo eleitorado do Estado por ele representado.

$\S 2^{\circ} \mathrm{O}$ eleitorado nacional poderá decidir a dissolução da Câmara dos Deputados, convocando-se nova eleição, que será realizada no prazo máximo de três meses.

$\S 3^{\circ} \mathrm{O}$ referendo previsto neste artigo realizar-se-á por iniciativa popular, dirigida ao Superior Tribunal Eleitoral, e exercida, conforme o caso, mediante a assinatura de dois por cento do eleitorado nacional, distribuído pelo menos por sete Estados, com não menos de cinco décimos por cento em cada um deles, ou mediante a assinatura de dois por cento do eleitorado estadual, distribuído pelo menos por sete Municípios, com não menos de cinco décimos por cento em cada um deles.

$\S 4^{\circ}$ Os signatários da iniciativa popular devem declarar o seu nome completo, a sua data de nascimento e o Município onde têm domicílio eleitoral, vedada a exigência de qualquer outra informação adicional.

$\S 5^{\circ} \mathrm{O}$ referendo para revogação do mandato do Presidente da República poderá também realizar-se mediante requerimento da maioria absoluta dos membros do Congresso Nacional, dirigido ao Tribunal Superior Eleitoral.

$\S 6^{\circ} \mathrm{O}$ referendo será considerado sem efeito, se a soma dos votos nulos e em branco corresponder a mais da metade do total dos sufrágios expressos.

$\S 7^{\circ}$ Se o resultado do referendo for contrário à revogação do mandato eletivo, não poderá ser feita nova consulta popular sobre o mesmo assunto, até a expiração do mandato ou o término da legislatura.

$\S 8^{\circ} \mathrm{O}$ referendo regulado neste artigo será convocado pelo Superior Tribunal Eleitoral.

$\S 9^{\circ}$ Os Estados, o Distrito Federal e os Municípios regularão, em suas respectivas Constituições e Leis Orgânicas, o referendo revocatório dos mandatos do chefe do Poder Executivo e dos membros do Poder Legislativo. Disponível em: <http://www.senado.gov.br/atividade/materia/detalhes.asp?p_cod_mate= 76146\&p_sort= DESC\&p_sort2=A\&p_a=0\&cmd=sort $>$. Acesso em: 25 abr. 2012.
} 
imperativo, pois os eleitos continuarão livres para desempenharem suas funções. Entretanto, se houver insatisfação com as políticas adotadas, poderá haver a convocação de referendo a fim de cassar ou não os mandatos.

Sobre essa relação de confiança entre o povo e os representantes, John Locke pondera:

[...] para a preservação da comunidade, não possa haver mais de um único poder supremo, que é o legislativo, ao qual todos os demais são e devem ser subordinados, contudo, sendo ele apenas um poder fiduciário para agir com vistas a certos fins, cabe ainda ao povo um poder supremo para remover ou alterar o legislativo quando julgar que este age contrariamente à confiança nele depositada. Pois, como todo poder concedido em confiança para se alcançar um determinado fim, sempre que este é manifestamente negligenciado, ou contrariado, o encargo confiado deve necessariamente ser retirado (forfeited) e voltar o poder às mãos daqueles que o concederam, que podem depositá-lo de novo onde quer que julguem ser melhor para sua garantia e segurança. E, portanto, a sociedade política conserva perpetuamente um poder supremo de salvaguardar-se das tentativas e propósitos de qualquer pessoa, mesmo de seus próprios legisladores, sempre que estes sejam tolos ou perversos o bastante para conceber e levar a cabo planos contrários às liberdades e propriedades dos súditos ${ }^{153}$. (grifos originais)

Em que pese o louvor na tentativa de implantação de mais um mecanismo de participação popular, seria melhor que houvesse a previsão de nova eleição, inclusive para os cargos de presidente e senador e não somente a cassação.

É que, dessa forma, ocorreria o mesmo problema que acontece após o impeachment, qual seja: quem assume a vaga é o vice (no caso do presidente) ou o suplente (no caso de senador). A tradição brasileira, entretanto, não prioriza os vices e suplentes, os quais concorrem em chapa única, porém com pouca visibilidade.

A lei eleitoral até prevê que "na propaganda dos candidatos a cargo majoritário, deverão constar, também, o nome dos candidatos a vice ou a suplentes de Senador, de modo claro e legível, em tamanho não inferior a 10\% (dez por cento) do nome do titular" (art. 36, $\S 4^{\circ}$, da Lei n. ${ }^{\circ}$ 9.504/1997). Contudo, tal exigência só fora incluída no ano de 2009, por meio da Lei n. ${ }^{\circ} 12.034$, demonstrando, desse modo, a falta de atenção para com esses cargos.

Diferentemente dos Estados Unidos, por exemplo, onde ocorrem até debates entre os candidatos ao cargo de vice, no Brasil eles ficam relegados ao segundo plano, sendo que muitos eleitores sequer sabem que o senador é eleito com dois suplentes (art. $46, \S 3^{\circ}$, da

\footnotetext{
${ }^{153}$ LOCKE, John. Dois tratados sobre o governo. Trad. Julio Fischer. $2^{\text {a }}$ ed. São Paulo: Martins Fontes, 2005. pp. 518-519.
} 
Constituição da República de 1988). Também mal se fala das funções dos vices e suplentes; além da substituição, o que fazem?

A Constituição da República de 1988 prevê no parágrafo único do art. 79 que, além de outras atribuições que lhe forem conferidas por lei complementar, fato que até o momento não ocorreu, o Vice-Presidente da República auxiliará o Presidente, sempre que por ele convocado para missões especiais. O vice-presidente tem, ainda, outras funções típicas, como a de integrar o Conselho da República (art. 89, I) e a de integrar o Conselho de Defesa Nacional (art. 91, I).

A experiência democrática demonstra, contudo, que esses cargos não são tão irrelevantes quanto possa se pensar. Além dos afastamentos de senadores que vão concorrer a outros cargos ou assumem ministérios ou secretarias no poder executivo, na história democrática brasileira recente, houve duas substituições de presidentes da república por seus vices. O primeiro caso foi a substituição do falecido presidente Tancredo Neves por José Sarney. E o segundo e mais emblemático foi a substituição de Fernando Collor de Melo deposto por meio de impeachment - por Itamar Franco.

Embora possa se pensar que, por ser chapa única, o eleitor queria deliberadamente escolher também o vice ou suplente, não se deve ignorar que o povo brasileiro tem uma grande tendência a atentar apenas para os candidatos titulares, motivo pelo qual, se realmente fosse adotado aqui o instrumento do recall, deveria se pensar na necessidade de uma eventual nova eleição, eventualmente, até com o vice concorrendo.

\subsection{A participação popular no Brasil}

Como visto, com a possibilidade de revogação dos cargos dos membros do Conselho de Procuradores, desde os tempos do Império identificam-se precedentes de participação popular no Brasil.

Nesse período ainda, a Constituição Política do Império do Brasil de 1824 previa também que qualquer do povo poderia ingressar com uma Ação Popular contra juízes e oficiais de justiça que cometessem suborno, peita, concussão ou peculato (art. 157). 
Já na transição para a República, há um embate histórico sobre um possível plebiscito referendário para aprovação da Constituição da República dos Estados Unidos do Brasil de 1891. Isso ocorreu porque o Decreto n. $^{\circ} 1$ de 15 de novembro de 1889 , o qual instituíra provisoriamente a República, previa em seu art. $7^{\circ}$ : "Sendo a Republica Federativa Brasileira a forma de governo proclamada, o Governo Provisório não reconhece nem reconhecerá nenhum governo local contrário à forma republicana, aguardando, como lhe cumpre, o pronunciamento definitivo do voto da nação, livremente expressado pelo sufrágio popular"154. (grifei)

Todavia, o texto constitucional previra apenas a promulgação pelo Congresso Nacional, após aprovado (art. $91^{155}$ ), silenciando sobre o tal "sufrágio popular" expressado no decreto instituidor da república provisória. Sendo assim, os monarquistas consideraram a proclamação da República nada mais que um golpe militar e não uma tentativa legítima de democratização ${ }^{156}$.

Nas primeiras manifestações do poder constituinte decorrente, alguns estados da federação implantaram em seus textos constitucionais a revogação de mandatos legislativos, ou recall. Foi esse o caso de São Paulo, Goiás, Rio Grande do Sul e Santa Catarina. Não havendo nenhum registro da utilização desses instrumentos, logo foram abolidos em reformas constitucionais $^{157}$.

Em que pese ter havido discussões no projeto constitucional de 1934, o texto aprovado não adotou a proposição de possibilidade de cassação do mandato do presidente da república, através de plebiscito, inspirada no modelo da Constituição gaúcha ${ }^{158}$.

A Constituição dos Estados Unidos do Brasil de 1937, a "Polaca", foi a primeira a considerar explicitamente a realização de plebiscito, inclusive como condição de sua implantação - art. 187. Todavia, o prazo de seis anos (art. 175 c/c art. 80) dado para a sua realização não fora cumprido, restando, pois, infrutífera a primeira previsão constitucional plebiscitária. Nessa mesma Carta foram previstas outras possibilidades para a realização de

\footnotetext{
154 Decreto n. ${ }^{\circ} 1, \quad$ de 15 de novembro de 1889. Disponível em: <http://www2.camara.gov.br/legin/fed/decret/1824-1899/decreto-1-15-novembro-1889-532625publicacaooriginal-14906-pe.html>. Acesso em 1 fev. 2012.

${ }_{155}$ Art 91 - Aprovada esta Constituição, será promulgada pela mesa do Congresso e assinada pelos membros deste.

${ }^{156}$ BENEVIDES, Maria Victoria de Mesquita. A cidadania ativa: referendo, plebiscito e iniciativa popular. cit. pp. 114-115.

${ }^{157}$ Ibid. p. 115 .
} 
plebiscitos: incorporação, divisão e desmembramentos de estados (art. $5^{\circ}$ ); legislações de competência do Conselho de Economia Nacional (art.63) e projetos de emendas constitucionais contrários à vontade presidencial, mas aprovados pelo Congresso (art. 174, $\S 4^{\circ}$ ). Porém, esses instrumentos nunca foram utilizados, motivo pelo qual acredita-se que a verdadeira intenção não era a participação popular, mas tão-somente conferir suposta legitimidade ao texto outorgado.

Assim, explica Paulo Bonavides: "Mais do que técnica plebiscitária, o que a Constituição dos Estados Unidos do Brasil de 1937 visava com as propostas de plebiscito era o despistamento para facilitar o jogo do poder"159.

Avançando no tempo, consolidado o fracasso da aprovação plebiscitária da Constituição dos Estados Unidos do Brasil de 1937, a Lei Constitucional n. 9 de 28 de fevereiro de 1945 excluiu definitivamente a consulta popular, por considerar que o Parlamento supriria, “com vantagem", a consulta e, ainda "que, por outro lado, o voto plebiscitário implicitamente tolheria ao Parlamento a liberdade de dispor em matéria constitucional" ${ }^{\prime 160}$.

Foi nesse cenário que surgiu a Constituição dos Estados Unidos do Brasil de 1946, pondo fim à ditadura Vargas. O texto restringiu-se ao modelo de representação pura, denotando apenas a consulta plebiscitária para a incorporação, subdivisão e desmembramento de Estados (art. $2^{\circ}$ ).

De tal modo, praticado no ínterim entre a Constituição dos Estados Unidos do Brasil de 1946 e a de 1967, o famoso plebiscito de 1963 não tinha previsão constitucional. À época, em 1961, João Goulart, o Jango, havia assumido a presidência em razão da renúncia de Jânio Quadros. Porém, devido à desconfiança, especialmente dos militares, quanto ao governo de Jango, o Congresso Nacional resolveu limitar os seus poderes, instituindo o parlamentarismo, através da Emenda Constitucional n. 4 de 2 de setembro de 1961, e condicionando à aprovação de um Conselho de Ministros todos os atos do presidente da república. A mesma

\footnotetext{
${ }^{158}$ Ibid. p. 116.

${ }^{159}$ BONAVIDES, Paulo. História constitucional do Brasil. Brasília: OAB, 2002. p. 346.

160 Lei constitucional n. 9 , de 28 de fevereiro de 1945. Disponível em: <http://www2.camara.gov.br/legin/fed/leicon/1940-1949/leiconstitucional-9-28-fevereiro-1945-365005publicacaooriginal-1-pl.html>. Acesso: 1 fev. 2012.
} 
emenda previu (art. $25^{161}$ ) a realização de plebiscito, a ser realizado em 1965, para consulta sobre a manutenção do parlamentarismo ou retorno ao presidencialismo.

Porém ,em 1962, a lei complementar n. ${ }^{\circ} 2$ antecipou para janeiro de 1963 a realização da consulta, designando-a referendum. Assim, embora a Emenda constitucional tivesse previsto um plebiscito para a continuação ou não do sistema de governo, a lei que regulamentou o dispositivo denominou-a referendo.

Devido ao golpe militar e implantação da ditadura, a Constituição da República de 1967, bem como a Emenda Constitucional n. ${ }^{\circ} 1$, de 17 de outubro de 1969, só previram a "consulta prévia às populações" no caso de criação de municípios (art. 14), abolindo-a para modificações territoriais nos Estados, deixando a criação destes a cargo somente do Congresso, através de lei complementar $\left(\operatorname{art} .3^{\circ}\right)$.

Com o processo de redemocratização, em especial o movimento das “Diretas Já", em meados da década de 80, o povo pleiteava o voto direto para a escolha direta de seus representantes. Além disso, buscava nos debates da Assembleia Constituinte meios para introduzir no futuro texto constitucional instrumentos de participação direta que possibilitassem a expressão de sua vontade.

Assim, o art. 14 prevê a utilização de plebiscito, referendo e iniciativa popular. Lembre-se que o anteprojeto constitucional pretendia incluir também o veto popular. Entretanto, esse não fora aprovado em segundo turno ${ }^{162}$. Além desses, há vários outros mecanismos de participação direta espalhados pela Constituição da República de 1988: os trabalhadores ganharam o direito de participar de deliberações governamentais sobre seus interesses profissionais e previdenciários (art. 10); participação de trabalhadores, empregadores e aposentados, além do governo, na gestão quatripartite da Seguridade Social (art. 194,inciso IV); participação popular na gestão do Sistema Único de Saúde (art. 198, inciso III), na gestão da Assistência Social (art. 204, inciso II), na gestão do ensino público

\footnotetext{
${ }^{161}$ Emenda Constitucional n. ${ }^{\text {4, de }} 2$ de setembro de 1961: Art. 25. A lei votada nos têrmos do art. 22 poderá dispor sôbre a realização de plebiscito que decida da manutenção do sistema parlamentar ou volta ao sistema presidencial, devendo, em tal hipótese, fazer-se a consulta plebiscitaria nove meses antes do têrmo do atual período presidencial. Disponível em: <http://www2.camara.gov.br/legin/fed/emecon/19601969/emendaconstitucional-4-2-setembro-1961-349692-publicacaooriginal-1-pl.html>. Acesso: 1 fev. 2012.

${ }^{162} \mathrm{O}$ veto popular estava previsto no art. 14, inciso IV do anteprojeto, todavia fora suprimido em $2^{\circ}$ turno de votação por 397 votos favoráveis à supressão, 12 contrários e 16 abstenções. $C f$. Ata da $318^{\text {a }}$ Sessão, em 16 de agosto de 1988. Publicado em Diário da Assembleia Nacional Constituinte. Número 293. Brasília, 17 de agosto de $1988 . \quad$ p. $419 . \quad$ Disponível em: <http://www2.camara.gov.br/atividade-
} 
(art. 206, IV); além da participação na fiscalização das contas públicas (arts. 31, § $3^{\circ}$ e 74, $\S 2^{\circ}$ ).

Ao estudar as formas de participação popular na democracia brasileira, percebe-se que elas podem se manifestar de duas formas: participação no processo político e decisório e no controle e fiscalização do $\operatorname{poder}^{163}$.

Através da participação no processo político e decisório, o povo age nas funções legislativa, executiva e judiciária, propondo leis, participando das decisões concernentes às políticas públicas e decidindo. São exemplos dessa forma de participação: o referendo, o plebiscito, a iniciativa popular e o júri popular. Certo também que se enquadram nessa classificação os orçamentos participativos e os conselhos de participação popular. Todavia, esses institutos têm caráter misto, uma vez que neles também são praticados atos fiscalizatórios.

Por outro lado, no controle e fiscalização do poder, o povo controla e fiscaliza os atos de governo, através de ações judiciais, denúncias aos órgãos de controle, etc. Os institutos que correspondem a essa forma de participação são: Ação Popular, Ação Civil Pública, Habeas Corpus, Mandado de Segurança, Mandado de Injunção (participação através do poder judiciário), além do controle dos serviços públicos, propriamente dito.

legislativa/legislacao/Constituicoes_Brasileiras/constituicao-cidada/publicacoes/anais-da-assembleia-nacionalconstituinte>. Acesso em: 28 fev. 2012.

163 ÁVILA, Caio Márcio de Britto. Mecanismos de democracia participativa no direito brasileiro. Dissertação de Mestrado, sob orientação do Professor Doutor Dalmo de Abreu Dallari, apresentada na Faculdade de Direito da Universidade de São Paulo, 2002. p. 39. 


\title{
3 PLEBISCITO E REFERENDO
}

\subsection{Distinção dos institutos}

Plebiscito e referendo possuem uma característica muito semelhante, qual seja: a consulta popular relativa às decisões governamentais, garantindo a participação direta do povo. Sendo assim, muitas vezes, há confusão semântica entre esses termos.

Para diferenciação dos institutos, alguns autores, especialmente os italianos, utilizam o critério do objeto da deliberação popular ${ }^{164}$. Destarte, o plebiscito é utilizado na deliberação sobre fatos ou acontecimentos, enquanto o referendo diz respeito a atos normativos. Como explica Biscaretti di Rufia:

\begin{abstract}
Malgrado doutrina e legislação usarem, frequentemente, de modo indistinto, os termos referendum e plebiscito, este último (sempre caracterizado por uma nota de excepcionalidade e extraordinariedade, de modo que está excluído de qualquer regulamentação uniforme, quer no âmbito interno como no internacional) deveria referir-se mais precisamente a uma manifestação do corpo eleitoral relativa não a um ato normativo ou administrativo (como o referendum), mas sim, a um mero fato ou evento [...] concernente à estrutura essencial do Estado ou do seu governo (por ex.: a adjudicação de território, a conservação ou a modificação de uma forma de governo, a designação de uma determinada pessoa a um certo cargo, etc...) ${ }^{165}$. (grifos originais)
\end{abstract}

Entretanto, há quem - como os doutrinadores franceses - distinga os institutos como a eleição de um homem, por plebiscito, e o voto relativo a um problema, por referendo. Em verdade, Maurice Duverger explica que uma das características do referendo é a "aprovação de um texto", ao passo que no plebiscito vota-se "por um nome", ou seja, passa-se a confiança a um homem para que ele elabore a política desejada pelo povo ${ }^{166}$.

Dessa maneira, Manoel Gonçalves Ferreira Filho ensina que, a fim de buscar uma conceituação mais precisa, evitando confusões entre os termos, a doutrina acabou por consignar que o "plebiscito seria uma consulta extraordinária e excepcional", a qual se refere a medidas de base ou de princípio, tais como a forma de Estado ou de governo, modificações das formas políticas, decisão acerca de mudanças de natureza territorial etc., ao passo que o

\footnotetext{
${ }^{164}$ GEMMA, Gladio. Verbetes: plebiscito e referendo. In: BOBBIO, Norberto e outros. Dicionário de política. cit. pp. 927 e 1074-1077.

${ }^{165}$ RUFFIA, Paolo Biscaretti di. Direito constitucional: instituições de direito público. Trad. Maria Helena Diniz. São Paulo: Revista dos Tribunais, 1984. pp. 378-379.

${ }^{166}$ DUVERGER, Maurice. Institutions politiques et droit constitutionnel. $11^{\mathrm{a}}$ ed. Paris: Presses Universitaires de France, 1955. p. 645.
} 
"referendo consubstanciaria o poder de aprovar as leis". Materializa-se na aprovação, ou não, de uma lei discutida e votada pelos representantes do povo. ${ }^{167}$.

Misturando os conceitos distintivos quanto ao momento e as matérias de que tratam o plebiscito e o referendo, Karl Loewenstein explica que o referendo é uma maneira de controle político para a confirmação ou rejeição de uma decisão política ou parlamentar já adotada, enquanto o plebiscito refere-se a matérias não constitucionais e não legislativas ${ }^{168}$.

A legislação brasileira, ao disciplinar plebiscito e referendo separadamente, nos incisos I e II do artigo 14, já sinalizou que não os trata como termos sinônimos. Mais adiante, no artigo 49, inciso XV, dispõe, ainda, que é competência do Congresso Nacional autorizar referendo e convocar plebiscito.

Com a edição da Lei n. ${ }^{\circ}$ 9.709, de 18 de novembro de 1998, regulamentando os incisos I, II e III do artigo 14 da Constituição da República de 1988, ficou clara a opção do legislador brasileiro em diferenciar plebiscito e referendo apenas pelo momento em que a consulta popular é dirigida aos cidadãos.

Assim, o artigo $2^{\circ}$ dispõe:

Art. $2^{\mathrm{o}}$ Plebiscito e referendo são consultas formuladas ao povo para que delibere sobre matéria de acentuada relevância, de natureza constitucional, legislativa ou administrativa.

$\S 1^{\mathrm{o}} \mathrm{O}$ plebiscito é convocado com anterioridade a ato legislativo ou administrativo, cabendo ao povo, pelo voto, aprovar ou denegar o que lhe tenha sido submetido.

$\S 2^{\circ} \mathrm{O}$ referendo é convocado com posterioridade a ato legislativo ou administrativo, cumprindo ao povo a respectiva ratificação ou rejeição.

(grifei)

Essa redação final, com a distinção legislativa adotada, foi explicada no Parecer da Comissão de Constituição, Justiça e Redação (CCJR), pelo relator, o deputado Almino Affonso, que ponderou que sempre houve e ainda há grande controvérsia em torno da conceituação dos institutos do plebiscito e do referendo. A polêmica não se restringe ao conceito ou à terminologia, mas também quanto à aplicação prática dos instrumentos.

\footnotetext{
${ }^{167}$ FERREIRA FILHO, Manoel Gonçalves. Curso de direito constitucional... p. 96.

${ }^{168}$ LOEWENSTEIN, Karl. Teoría de la constitución. Trad. Alfredo Gallego Anabitarte. Barcelona: Ariel, 1982. p. 326 e seg.
} 
Assim, por considerar que o Brasil não tinha a tradição jurídica e política necessária para definir com clareza os contornos dessas modalidades de exercício da soberania popular, as quais, com a dimensão adotada $^{169}$, se inscreviam pela primeira vez em um texto constitucional, o legislador optou pela diferenciação apenas pelo momento em que a consulta é realizada ${ }^{170}$.

E, embora o dispositivo não esclareça o que é matéria de acentuada relevância, seus parágrafos deixam clara a intenção legislativa de diferenciar os institutos apenas pelo momento da consulta: antes ou depois do ato legislativo ou administrativo, respectivamente, plebiscito e referendo.

Não é outra a lição de José Afonso da Silva, que também afirma que o plebiscito e o referendo são consultas populares semelhantes. A diferença reside no fato de que, enquanto o plebiscito "visa a decidir previamente uma questão política ou institucional, antes de sua formulação legislativa", o referendo "versa sobre a aprovação de textos de projeto de lei ou de emenda constitucional, já aprovados". Assim, conclui o autor, que a função do referendo é ratificar (confirmar) ou rejeitar um projeto aprovado, ao passo que a do plebiscito é autorizar a formulação da medida requerida pela consulta popular ${ }^{171}$.

Na prática, a própria Constituição da República de 1988 define a realização de plebiscito prévio para os casos de modificações territoriais em estados e municípios (artigo 18, parágrafos $3^{\circ}$ e $4^{\circ}$ ) e o artigo $2^{\circ}$ do Ato das Disposições Constitucionais Transitórias também previu a realização de plebiscito para a escolha da forma (república ou monarquia constitucional) e do sistema de governo (parlamentarismo ou presidencialismo).

De outro lado, o único referendo ${ }^{172}$ que tivemos em nível federal tratou justamente de um ato legislativo - o Estatuto do desarmamento (lei n. ${ }^{\circ} 10.826$ de 22 de dezembro de 2003), o qual previa a realização de um referendo para proibir ou não a comercialização de armas de fogo (artigo 35, parágrafo $1^{\circ}$ ). Desse modo, na prática, as consultas brasileiras fizeram diferenciação em razão da matéria, ainda que a lei não a tenha feito.

\footnotetext{
${ }^{169}$ É certo que o plebiscito já fora previsto em Constituições anteriores à de 1988, contudo alcançando menos hipóteses de aplicação.

${ }^{170}$ AFFONSO, Almino Monteiro Álvares. Parecer sobre o projeto de lei $n .^{\circ} 3.589 / 1993$. In: Diário da Câmara dos Deputados, ago. $1996 . \quad$ p. $22355 . \quad$ Disponível em: <http://imagem.camara.gov.br/dc_20.asp?selCodColecaoCsv=D\&Datain=10/08/1996\&txpagina=22335\&altura= 650\&largura=800>. Acesso em: 5 mar. 2012.

${ }^{171}$ AFONSO DA SILVA, José. Curso de direito constitucional. cit. p. 142.

${ }^{172}$ Sobre a natureza da consulta se plebiscito ou referendo, ver item 2.3.
} 
Seguindo essa linha distintiva - plebiscito para políticas governamentais e referendo nos casos de rejeição ou ratificação de normas - Paulo Bonavides esclarece, ainda, que alguns doutrinadores do Direito Público defendem que o plebiscito se caracteriza como um "pronunciamento popular válido por si mesmo", além de ser um ato unilateral e independente da participação de qualquer outro órgão do Estado, de modo que prevalece completamente a vontade popular, manifestada sem a colaboração direta do Legislativo. Analisado sob essa acepção, o plebiscito, diferentemente do que previam as antigas doutrinas, se erige à esfera das decisões legislativas. Contudo, compreende "todas as leis que não resultem da obra comum do Parlamento e do povo". De outro lado, o referendo abrange a legislação que depende da ação sucessiva do parlamento e do povo, pois necessita da anuência de ambos os órgãos ${ }^{173}$.

Nesses termos, em apertada síntese, pode-se dizer que o referendo consiste em aceitar ou rejeitar uma única opção, enquanto o plebiscito se refere à escolha entre duas (ou mais) opções, sendo que a escolhida servirá de parâmetro para a atuação governamental.

Por fim, há de se consignar também aqueles que consideram desnecessária qualquer distinção entre plebiscito e referendo, uma vez que não se percebe relevante diferença entre ambos. Essa é a opinião de Gladio Gemma ${ }^{174}$ :

A noção de plebiscito é controversa.

$[\ldots]$

É, pois, uma votação popular sobre assuntos de relevância constitucional, sendo, por isso, um instrumento de democracia direta, se bem que, como todos os dispositivos deste tipo, possa ser instrumentalmente usados por correntes autoritárias ou totalitárias para legitimar o seu poder autocrático. Ora, tal definição poderá parecer parcial e incompleta, já que não permite estabelecer uma clara distinção entre plebiscito e um instituto análogo, o referendum.

$[\ldots]$

O dois termos são, a rigor, sinônimos. Apenas pode-se observar uma certa diferença histórica no uso de um ou outro termo.

\footnotetext{
${ }^{173}$ BONAVIDES, Paulo. Ciência política. cit. p. 310.

${ }^{174}$ GEMMA, Gladio. Verbete: plebiscito. In: BOBBIO, Norberto e outros. Diccionário de política. cit. p. 927.
} 


\subsection{REFERENDO}

\subsubsection{Etimologia e histórico}

O termo referendo vem da expressão latina ad referendum que significa aquilo que deve ser submetido a alguém ${ }^{175}$, em geral, "se refere a um ato de ratificação de outro ato",176, por meio da "decisão do corpo legislativo"177.

Embora a Constituição da República de 1988 utilize o termo, inclusive, com a acepção de controle que um poder ou autoridade exerce sobre outros ${ }^{178}$, seu significado mais conhecido é o de instrumento de participação popular direta no processo legislativo, realizado após um ato governamental. Por esse motivo, na prática, referendo passou a ser sinônimo de consulta popular ${ }^{179}$. No conceito de Dalmo de Abreu Dallari: “consulta à opinião pública para a introdução de uma emenda constitucional ou mesmo de uma lei ordinária, quando esta afeta um interesse público relevante" ${ }^{\prime 180}$.

Quanto ao surgimento do instituto, há divergências doutrinárias. Maria Victoria Benevides remonta suas origens ao século XV, na Suíça, onde consultas diretas eram feitas às populações de alguns cantões ${ }^{181}$. Esse também é o entendimento de Dalmo de Abreu Dallari:

\footnotetext{
${ }^{175}$ Do latim referendum aquilo que deve ser sujeito ou submetido a alguém. Gerundivo de reférre: relatar, fazer uma relação, submeter a, sujeitar a, apresentar a. Fonte: Dicionário Houaiss. Disponível em: <http://houaiss.uol.com.br/busca.jhtm?verbete=referendum\&stype=k>. Acesso em: 9 jan. 2012.

${ }^{176}$ AFONSO DA SILVA, José. O sistema representativo e a democracia semi-direta. cit. p. 100.

177 SCHMITT, Carl. Democrazia e liberalismo. Trad. italiana Manuela Alessio. Milão: Giuffrè Editore, 2001. p. 28.

${ }^{178}$ Art. 84. Compete privativamente ao Presidente da República:

$[\ldots]$

VIII - celebrar tratados, convenções e atos internacionais, sujeitos a referendo do Congresso Nacional;

$[\ldots]$

XIX - declarar guerra, no caso de agressão estrangeira, autorizado pelo Congresso Nacional ou referendado por ele, quando ocorrida no intervalo das sessões legislativas, e, nas mesmas condições, decretar, total ou parcialmente, a mobilização nacional;

$[\ldots]$

XX - celebrar a paz, autorizado ou com o referendo do Congresso Nacional;

Art. 87. [...]

Parágrafo único. Compete ao Ministro de Estado, além de outras atribuições estabelecidas nesta Constituição e na lei:

I - exercer a orientação, coordenação e supervisão dos órgãos e entidades da administração federal na área de sua competência e referendar os atos e decretos assinados pelo Presidente da República; $[\ldots]$

${ }^{179}$ BENEVIDES, Maria Victoria de Mesquita. A cidadania ativa: referendo, plebiscito e iniciativa popular. cit. p. 34.

${ }^{180}$ DALLARI, Dalmo de Abreu. Elementos de teoria geral. cit. p. 154.

${ }^{181}$ BENEVIDES, Maria Victoria de Mesquita. A cidadania ativa: referendo, plebiscito e iniciativa popular. cit. p. 34.
} 
A origem do referendum se encontra nas antigas Dietas das Confederações Germânicas e Helvéticas, quando todas as leis eram aprovadas ad referendum do povo $^{182}$.

Yannis Papadopoulos ${ }^{183}$ detalha melhor essa origem explicando que já no século XII os cantões suíços da parte italiana praticavam a democracia direta. Posteriormente, no século XIII, é que surgiram as Landsgemeiden, assembleias reunidas anualmente com poderes de escolher autoridades, editar leis, declarar guerra, celebrar tratados, etc., ou seja, o povo diretamente referendava os atos de governo ${ }^{184}$.

De outro lado, Maria Benedita Malaquias Pires Urbano, dividindo em seis fases o surgimento histórico do referendo, ressalta que o instituto, assim como o entendemos modernamente, se origina, ao menos em teoria (primeira fase - teórica), no último quarto do século XVIII em França, durante os debates pós-revolucionários para a implantação do regime representativo (defendido por Montesquieu) ou de uma democracia direta (lecionada por Rousseau). A autora considera que tanto os referendos realizados nos cantões suíços desde o século XV, bem como referendos constitucionais realizados nos Estados Unidos da América (e.g. referendo constitucional em Massachussetts em 1778), embora sejam manifestações populares, não se enquadram no conceito moderno de referendo, por lhes faltar contextualização com forma de governar $^{185}$.

Já a segunda fase - francesa (primeira metade do século XIX) corresponde ao período das consultas napoleônicas, sem considerar a natureza plebiscitária ou referendária. A autora explica que Napoleão Bonaparte e Luís Napoleão se utilizaram do instituto para legitimar tanto seu poder pessoal quanto sua atuação governamental concreta. Nesse mesmo período, na Suíça, se impunha, em níveis cantonais e federais, a institucionalização dos mecanismos de participação direta nas matérias legislativas e constitucionais ${ }^{186}$.

Durante a segunda metade do século XIX até sua última década, tem-se a terceira fase - helvética/americana, na qual o referendo se expandia nos estados norte-americanos (portanto, mais em nível estadual do que federal) e na Confederação Suíça. Ambos os casos

\footnotetext{
${ }^{182}$ DALLARI, Dalmo de Abreu. Elementos de teoria geral. cit. p. 154.

183 Ver item 1.2.

184 PAPADOPOULOS, Yannis apud AFONSO DA SILVA, José. O sistema representativo e a democracia semi-direta. cit. p. 96.

185 URBANO, Maria Benedita Malaquias Pires. O referendo. Perfil histórico-evolutivo do instituto. Configuração jurídica do referendo em Portugal. cit. pp. 10 e seg.

${ }^{186}$ Ibid. pp. 22-23.
} 
refletiam mais uma opção consciente por esse modelo democrático semidireto do que uma imposição por fatores políticos. Essa consagração se deve à tradição democrática e à estrutura federativa descentralizada desses dois países.

Acrescente-se, ainda, no caso dos Estados Unidos, a rígida separação de poderes, a qual propiciava aos órgãos constitucionais buscarem na participação direta uma forma de ultrapassar as barreiras impostas pelos outros órgãos, e, também, um instrumento utilizado pela oposição governamental no combate ao desinteresse e à corrupção que assolavam alguns parlamentos da nação ${ }^{187}$. Nesse contexto, vale lembrar que os referendos realizados nos estados norte-americanos tratavam, principalmente, de matéria financeira como empréstimos e criação de impostos, claramente a fim de imiscuir a população nas escolhas políticas e no combate à corrupção ${ }^{188}$.

A quarta fase - compatibilidade do referendo com o sistema representativo parlamentar - compreendeu a última década do século XIX até a quarta década do século XX. Caracterizou-se pelo aumento do instituto referendário nos países europeus, estimulado, principalmente, pelas experiências norte-americana e suíça e também pelos referendos internacionais (com a finalidade de resolver questões territoriais após a I Guerra Mundial).

Todavia, especialmente em França, o crescimento da participação popular não foi sereno. Havia a desconfiança de sua descompatibilização com o sistema parlamentar, diante da ausência de previsão constitucional, estimulado, ainda, pelo desprestígio das consultas napoleônicas e receio em desestabilizar a recém-instaurada República Francesa. De qualquer maneira, o referendo ganhou força no concernente ao combate às disfuncionalidades do parlamentarismo e, com o advento dos referendos de arbitragem (referendo para dissolução das Câmaras e referendo para revocação do Chefe de Estado), o povo passou a exercer um maior controle sobre os órgãos executivo e legislativo, a fim de equilibrar os poderes, retirando o protagonismo do executivo sem, contudo, deixar o parlamento desenfreadamente poderoso $^{189}$.

O período que vai do final da II Guerra Mundial até o início dos anos de 1970 corresponde à quinta fase - retração, na qual os referendos ocorreram em pouca quantidade e

\footnotetext{
${ }^{187}$ Ibid. pp. 24-25.

${ }^{188}$ MELLO, Oswaldo Aranha Bandeira de. O referendum legislativo popular. São Paulo: Revista dos Tribunaes, 1935. p. 52.

189 URBANO, Maria Benedita Malaquias Pires. O referendo. Perfil histórico-evolutivo do instituto. Configuração jurídica do referendo em Portugal. cit. pp. 25-38.
} 
para a resolução de problemas institucionais, geralmente ocorridos no pós-guerra (escolha entre monarquia e república na Itália e Grécia em 1946; regresso da monarquia na Bélgica em 1950; independência e instituição da república na Islândia em 1944; referendos ocorridos nos anos de 1940, 1950 e 1960, convocados pelo governo provisório do general De Gaulle, a fim de instaurar uma nova Constituição para a França) ${ }^{190}$.

A sexta fase, que tem lugar até os dias atuais, vem se caracterizando pela bipolaridade entre euforia de alguns e desânimo de outros. Sendo visto um crescimento referendário, sobretudo na Itália, pode-se constatar que, se houvera antes uma intenção em combater as vicissitudes do sistema representativo pela implementação de uma democracia direta ou semidireta, hoje há de se considerar a participação popular apenas como um paliativo aos problemas gerados pela representação política e não, talvez, a salvação desta ${ }^{191}$.

\subsubsection{Conceito e classificação}

A fim de delimitarmos o conceito de referendo, apresentamos uma classificação, seguindo as modalidades propostas por Paulo Bonavides ${ }^{192}$ :

a) Quanto à matéria ou objeto: constitucional ou legislativo. $O$ referendo constitucional tem cabimento nas "disposições pertinentes à essência do Estado, sua organização, suas funções e sua dinâmica na relação com o indivíduo"193, vindo a ser aplicado tanto na reforma constitucional quanto nos limites do poder constituinte originário. Já o referendo legislativo diz respeito às leis infraconstitucionais.

É importante ressaltar, entretanto, que a lei brasileira ${ }^{194}$ possibilita, ainda, a realização de referendo ou plebiscito que versem sobre matérias administrativas. Contrariamente a essa matéria, argumenta-se que fere a separação de poderes e a autonomia do poder executivo. Gilberto Bercovici, todavia, explica que essa visão é "mais ortodoxa que a do próprio

\footnotetext{
${ }^{190}$ Ibid. pp. 38-39.

${ }^{191}$ Ibid. pp. 39-44.

192 BONAVIDES, Paulo. Ciência política. cit. p. 303-304.

193 ROCHA, Cármen Lúcia Antunes. O referendum e a representação democrática no Brasil. In: Revista de informação legislativa. Número 92. Brasília, $1986 . \quad$ Disponível em: http://www2.senado.gov.br/bdsf/item/id/181747. Acesso em: 28 fev. 2012. p. 27.

${ }^{194}$ Lei n. ${ }^{\circ} 9.709 / 1998$ - Art. $2^{\circ}$ Plebiscito e referendo são consultas formuladas ao povo para que delibere sobre matéria de acentuada relevância, de natureza constitucional, legislativa ou administrativa. (grifei)
} 
Montesquieu", que não preconizava uma separação absoluta entre os poderes. Além disso, o povo é o detentor do poder, e a soberania popular é um dos pilares do Estado Democrático de Direito $^{195}$.

b) Quanto aos efeitos: constitutivo ou ab-rogativo. O referendo ab-rogativo tem a função de anular, total ou parcialmente, uma norma existente, e.g. art. 75 da Constituição italiana ${ }^{196}$. De outro lado, o referendo constitutivo é instrumento de participação popular legislativa sobre um ato que pode ser ou já foi aprovado pelo Legislativo $^{197}$.

c) Quanto à natureza jurídica: obrigatório ou facultativo. Haverá referendo obrigatório quando a criação legislativa depender constitucionalmente de consulta popular. Todavia, haverá referendo facultativo quando órgão competente requerer a manifestação do eleitorado.

A Federação Suíça adota os dois tipos de referendo. O obrigatório nos casos de revisão constitucional, filiação a organizações de segurança coletiva ou supranacionais, leis federais urgentes e sem embasamento na Constituição, além de todas as iniciativas populares com fins de revisão constitucional total ou parcial, se rejeitadas pela Assembleia Federal. Já o referendo facultativo tem por objeto as leis federais, as decisões federais - se a Constituição ou a lei estabelecerem - e alguns acordos internacionais ${ }^{198}$.

d) Quanto ao tempo da consulta: ante legem ou post legem. Referendo ante legem, anterior, consultivo, preventivo ou programático ocorre antes da elaboração da norma, buscando-se previamente conhecer a opinião dos eleitores sobre determinado tema. Por exclusão, o referendo post legem, sucessivo ou póslegislativo corresponde à consulta popular realizada após a edição da lei.

\footnotetext{
${ }^{195}$ BERCOVICI, Gilberto. Referendo popular sobre matéria administrativa - constitucionalidade. In: Revista Trimestral de Direito Público 49/50. São Paulo: Malheiros, 2005. p. 213 e 219.

${ }^{196}$ Constituição italiana - art. 75 - Deverá ser realizado referendo popular para deliberar a ab-rogação, total ou parcial, de uma lei ou de um ato com força de lei, quando solicitado por 500 mil eleitores ou cinco Conselhos Regionais. (traduzi). Disponível em: <http://www.governo.it/Governo/Costituzione/2_titolo1.html>. Acesso em: 1 fev. 2012.

${ }^{197}$ FERREIRA FILHO, Manoel Gonçalves. Do processo legislativo. cit. p. 152.

198 Constituição suíça. Arts. 140 e 141. Disponível em: <http://www.admin.ch/ch/f/rs/101/index.html>. Acesso em: 10 abr. 2012.
} 
Alguns autores ${ }^{199}$ e também a legislação brasileira pretendem diferenciar o referendo do plebiscito pelo momento em que a consulta é realizada. Assim, se a consulta é posterior ao ato legislativo trata-se de referendo, se anterior, plebiscito.

Esse critério de distinção resta equivocado para aqueles que diferenciam plebiscito de referendo consultivo - convocado pelo Legislativo para que os cidadãos deliberem previamente sobre um projeto de $1 \mathrm{ei}^{200}$. Porém, ressalta Dalmo de Abreu Dallari "que alguns preferem considerar [o plebiscito] apenas um referendum consultivo" ${ }^{201}$. Nesse sentido, Maria Victoria de Mesquita Benevides salienta que se trata de plebiscito quando a consulta é realizada antes da edição legislativa:

A questão que se coloca, a meu ver, é a percepção de que tais consultas - de resultado "indicativo" - devem ser entendidas como plebiscitos (na definição aqui adotada) e não como referendos. Aliás, a França e os Estados Unidos não utilizam o termo plebiscito, e, portanto, o adjetivo “consultivo" é compreensível ${ }^{202}$.

A Constituição Espanhola de 1978, por exemplo, adota a expressão "referendo consultivo", no item 1 de seu art. 92: “As decisões políticas de especial transcendência poderão ser submetidas a referendo consultivo de todos os cidadãos."203 Curioso é que, no projeto original, falava-se só em referendo, tendo sido, todavia, acrescentado no texto final o adjetivo consultivo ${ }^{204}$. Dentre os possíveis motivos para qualificar o referendo como consultivo, tem-se a diferenciação entre este e outros tipos de referendo. Primeiro, para diferenciá-lo do referendo de ratificação - mal utilizado pelos governos gaullista em França e franquista na Espanha; segundo, a fim de evitar confusão com o referendo abrogatório

\footnotetext{
${ }^{199}$ Para Manoel Gonçalves Ferreira Filho: “[...] o referendo consubstanciaria o poder de aprovar as leis. Seria a decisão popular sobre lei discutida e votada pelos representantes do povo." In: FERREIRA FILHO, Manoel Gonçalves. Curso de direito constitucional... p. 96. No mesmo sentido, José Afonso da Silva: “[...] o referendo versa sobre a aprovação de textos de projeto de lei ou de emenda constitucional, já aprovados; o referendo ratifica (confirma) ou rejeita o projeto aprovado." In: AFONSO DA SILVA, José. Curso de direito constitucional. cit. p. 142.

${ }^{200}$ Marcos Antônio Striquer Soares considera equivocada a distinção de plebiscito e referendo pelo tempo da consulta, pois esta ocorre antes da promulgação do ato legislativo, tanto no plebiscito quanto no referendo consultivo. Assim, para o autor, a diferença entre os institutos existe porque o plebiscito "autoriza um campo de liberdade maior ao Poder Legislativo". In: SOARES, Marcos Antônio Striquer. O plebiscito, o referendo e o exercício do poder. São Paulo: Instituto Brasileiro de Direito Constitucional, 1998. pp. 58 e 91.

${ }^{201}$ DALLARI, Dalmo de Abreu. Elementos de teoria geral. cit. p. 154.

202 BENEVIDES, Maria Victoria de Mesquita. A cidadania ativa: referendo, plebiscito e iniciativa popular. cit. p. 135 .

${ }^{203}$ Constituição espanhola. Disponível em: <http://www.congreso.es/consti/constitucion/indice/index.htm>. Acesso em 23 fev. 2012. (traduzi)

204 Cf. "Sinopsis artículo 29 Disponível

<http://www.congreso.es/consti/constitucion/indice/sinopsis/sinopsis.jsp?art=92\&tipo=2>. Acesso em:

23 fev. 2012.
} 
italiano; por fim, sem olvidar as possíveis interpretações quanto à vinculação do resultado do referendo, uma vez que, considerando-se apenas consultivo, poderia ser interpretado como não obrigatório ao governo ${ }^{205}$.

Em que pese a importância da caracterização do referendo pelo momento em que é feita a consulta popular, há outros elementos identificadores do instituto, por exemplo, a participação do povo no processo legislativo, o caráter vinculante - que será melhor abordado adiante - e, talvez, o aspecto mais importante, qual seja, a ratificação ou rejeição do eleitorado sobre uma proposta.

O referendo consiste em aceitar ou rejeitar uma única opção posta à votação. Por outro lado, o plebiscito permite a escolha entre duas (ou mais) opções, sendo que a eleita servirá de parâmetro para a atuação governamental. O instituto referendário presta-se, portanto, a ratificar ou rejeitar uma decisão já estabelecida.

Ademais, a consulta referendária permite ao povo a impressão de sua vontade diretamente nos atos normativos, deixando o corpo eleitoral menos dependente dos seus representantes e o integrando ao processo legislativo, de modo a conferir aos cidadãos "poder de decisão a respeito das leis que os obrigarão"206.

\subsection{PLEBISCITO}

\subsubsection{Etimologia e histórico}

Etimologicamente, plebiscito vem do latim plebis (plebe) + scitum (decreto) $^{207}$. Na República Romana significava a decisão soberana da plebe aprovada em assembleia,

\footnotetext{
${ }^{205}$ CRUZ VILLALÓN, Pedro. El referéndum consultivo como modelo de racionalización constitucional. In: Revista de Estudios Políticos. Número 13. Madrid, 1980. Disponível em: <http://dialnet.unirioja.es/servlet/dcart?info=link\&codigo=26601\&orden=0>. Acesso em: 23 fev. 2012.

${ }^{206}$ SILVA, Daniela Romanelli da. Democracia e direitos políticos. cit. p. 196.

${ }^{207}$ Do latim plebiscítum,i ou plebiscítus,us 'plebiscito, lei romana aprovada pelos plebeus', formado de plebi(genitivo de plébs,ébis 'a classe do povo, a plebe') + scitum 'decreto', neutro do particípio passado de sciscíre 'saber, conhecer, reconhecer, poder, ser capaz de, decidir (depois de tomar conhecimento), aprovar. Fonte: Dicionário Houaiss. Disponível em: 〈http://houaiss.uol.com.br/busca.jhtm?verbete=plebiscito〉. Acesso em: 29 dez. 2011.
} 
obrigando, inicialmente, apenas os plebeus e, após a Lex Hortencia de Plebiscito (aprox. 286 a.C.), aplicara-se também aos patrícios, obrigando, destarte, a todos ${ }^{208}$.

Tendo origem em Roma, o plebiscito era a deliberação da plebe, ou seja, a classe "excluída", constituída em grande parte por estrangeiros, povos das terras conquistadas pelos romanos. Além disso, apesar de estar em maior número, eram preteridos pelos patrícios aristocratas, descendentes das famílias que deram origem à cidade e detinham os privilégios políticos.

Durante o reinado de Sérvio, devido aos seus constantes desentendimentos com os patrícios, os plebeus começaram a conquistar alguns privilégios, como a posse de algumas terras e se tornarem parte de uma tribo, especialmente criada para eles, de tal modo que entraram definitivamente para a cidade ${ }^{209}$.

Todavia, após o assassinato de Sérvio, os patrícios retiraram dos plebeus o direito de propriedade e todos os benefícios dados a eles pela monarquia. Destarte, novamente à margem da sociedade, a classe plebeia pretendia abandonar Roma a fim de encontrar um local onde pudesse exercer a liberdade. Esse fato, porém, assustou parte do patriciado, que perderia boa parte de seus soldados plebeus, deixando a cidade à mercê dos inimigos. De outro lado, os plebeus também perceberam que o isolamento, embora lhes garantisse liberdade, não lhes proporcionava felicidade, pois não tinham elementos (sacerdotes, magistrados, leis, etc.) para formar uma cidade. Desse modo, embora reconhecendo suas diferenças, essas classes perceberam que deviam permanecer juntas, e para selar a reconciliação foi dada à plebe o direito de escolher seus chefes - os tribunos, aos quais foram atribuídos poderes religiosos e políticos semelhantes aos magistrados patrícios ${ }^{210}$.

A partir desse momento, a plebe passou também a ter suas assembleias deliberativas para tratar dos seus próprios interesses e os decretos decorrentes dessas deliberações foram chamados plebiscitos (decreto da plebe) em contraposição aos decretos patrícios (senatusconsulto) $)^{211}$.

Com o aumento de poder dos plebeus, estes conseguiram abolir os privilégios religiosos e alcançaram os importantes postos políticos de Roma: magistraturas, sacerdócio e

\footnotetext{
${ }^{208}$ SGARBI, Adrian. O referendo. Rio de Janeiro: Renovar, 1999. p. 104.

${ }^{209}$ COULANGES, Fustel de. A cidade antiga. cit. pp. 311-312.

${ }^{210}$ Ibid. pp. 314-320.

${ }^{211}$ Ibid. p. 323.
} 
consulados. Enfim, após a Lex Hortencia de Plebiscito, as decisões plebiscitárias aplicaram-se também aos patrícios.

Com o passar do tempo, o plebiscito voltou a ser utilizado. Entretanto, não mais na forma de instrumento de participação popular, como fora outrora em Roma, mas com a finalidade de manter ou reforçar o poder dos governantes. Esse foi o caso dos plebiscitos napoleônicos em França, que ficaram famosos por legitimar o poder de um homem, garantindo-lhe que sua escolha política tivesse apoio popular.

Assim foram os plebiscitos de Napoleão Bonaparte relativos ao Consulado (1799), à vitaliciedade do Cônsul (1802) e à coroa hereditária do Império (1804), bem como os de Luís Napoleão para restaurar o Império (1852), para aprovar a Constituição outorgada a fim de evitar a queda do mesmo Império $(1870)^{212}$.

Essas atitudes totalitaristas, a fim de maquiar o apoio popular, foram criticadas pelos socialistas da época, que dirigiam críticas às consultas e exaltavam o governo representativo, ao que Luís Napoleão respondia: o plebiscito "é a economia de uma revolução"213.

Embora adormecido por um período, no qual os representantes - como Jules Simon não queriam dar ao povo o direito de discutir em seu lugar, na V República francesa o general-presidente, Charles De Gaulle, retomara a utilização dos plebiscitos para a confirmação de seu mandato (1961, 1962 e 1969), sobre a independência da Argélia (1961). Fica evidenciado o caráter de "voto de confiança" - nas palavras de Duverger - a um homem, o general-presidente ${ }^{214}$.

Esse quadro de emprego deturpado do plebiscito gerou nos franceses uma repulsa ao instituto $^{215}$. Todos o viam e até hoje o veem como uma degeneração do referendo. Duverger critica os plebiscitos utilizados com a coação moral do povo, amedrontado pela possibilidade de instauração do caos, caso votem contrariamente ao líder.

Somam-se a esses, exemplos outros de bonapartismo plebiscitário: o plebiscito de 1938, convocado por Hitler para anexação da Áustria; os que aprovaram a anexação dos

\footnotetext{
$\overline{212}$ BONAVIDES, Paulo. Ciência política. cit. p. 304.

${ }^{213}$ BENEVIDES, Maria Victoria de Mesquita. A cidadania ativa: referendo, plebiscito e iniciativa popular. cit. pp. 59-60.

${ }^{214}$ Ibid. pp. 60-61.
} 
países bálticos à União Soviética (1939) e os de criação da "República Árabe" (1958), fundindo Egito e Síria ${ }^{216}$.

Recentemente, vêm sendo questionados os plebiscitos (ou referendos) realizados em alguns países sul-americanos: Venezuela, Equador e Bolívia. Na Venezuela, por exemplo, Hugo Chávez pretendia o apoio popular na reforma constitucional que o levaria à possibilidade de reeleições infinitas. $\mathrm{O}$ receio de que os instrumentos de participação direta possam ser desvirtuados assusta, principalmente, aquelas nações com democracias consolidadas há pouco tempo.

Nesse sentido, Canotilho explica que as heranças plebiscitárias da República de Weimer e as gaullistas repercutiram negativamente contra a introdução das consultas diretas, inclusive em Portugal. O autor atesta que a aprovação plebiscitária do texto constitucional de 1933, bem como as tentativas plebiscitárias revisionistas - as quais continuaram mesmo após a aprovação da Constituição portuguesa de 1976 - "reforçaram as dúvidas quanto à bondade democrática dos esquemas de democracia semidireta"217.

Contudo, o mau uso dos institutos de participação direta não pode ser invocado com a finalidade de extirpá-los. Hão de se garantir meios para que as consultas reflitam a verdadeira vontade popular, a fim de trazer o cidadão para a participação política.

\subsubsection{Conceito}

Diante das circunstâncias históricas, percebe-se haver uma variação acerca do conceito de plebiscito. Aqueles que repelem os plebiscitos por ter tido caráter populista preferem abarcar todas as consultas populares sob a bandeira do referendo. Entretanto, principalmente analisando-o na prática, é possível delimitar conceitualmente o plebiscito.

O plebiscito é o instituto de consulta direta do povo, em geral, para questões de políticas essenciais ao Estado. Assim, seu objeto não é um ato normativo (como no referendo), mas sim a adoção, por parte das autoridades públicas, de determinada decisão

\footnotetext{
${ }^{215}$ Essa repulsa é tanta que os autores fazem questão de distingui-los, a fim de que não se confunda o referendo atualmente adotado com os plebiscitos cesaristas. Cf. ROSANVALLON, Pierre. La démocratie inachevée. cit. p. 309.

${ }_{216}$ Ibid. p. 62.

${ }^{217}$ CANOTILHO, José Joaquim Gomes. Direito constitucional e teoria da Constituição. $7^{\mathrm{a}}$ ed. Coimbra: Almedina, 2003. p. 297.
} 
popular importante para a estrutura estatal. Como explica Daniela Romanelli da Silva, ressaltando, ainda, sua natureza de direito político:

\begin{abstract}
Mais do que uma consulta ao povo acerca de uma decisão a ser tomada, ou "guiar as autoridades para que tomem decisões de acordo com a vontade popular" como preleciona Manoel Gonçalves Ferreira Filho, o plebiscito é um direito político que contém ou deve conter poder decisório do povo a respeito de fatos tidos como importantes para as condições essenciais do Estado. Em geral, os plebiscitos não se prestam para que o povo adote atos normativos, eles servem para que os cidadãos emitam juízo a respeito de uma questão e, dependendo desse juízo, uma norma deverá ser elaborada ${ }^{218}$.
\end{abstract}

\title{
3.4 A EXPERIÊNCIA BRASILEIRA
}

\subsubsection{Regulamentação}

Baseando-se nas aplicações em outros países e aproveitando as experiências práticas, embora parcas, as constituições e leis de âmbito nacional e estadual regulamentam a utilização do plebiscito e referendo. E assim como quaisquer institutos jurídico-políticos, há ainda várias propostas de emendas constitucionais e projetos de lei com a finalidade de aperfeiçoar essas consultas diretas.

\subsubsection{Previsões constitucionais e legais}

Os institutos de democracia direta, plebiscito e referendo, estão constitucionalmente previstos no art. 14, incisos I e II. Convém ressaltar que, apesar de já haver textos anteriores que fizessem referências a eles, a atual Carta os colocou em local de destaque, no capítulo de direitos políticos. Assim, diferentemente das anteriores, que disciplinavam a utilização desses mecanismos para casos específicos como a fusão, incorporação e desmembramento de estados ou para aprovação do texto constitucional, a Constituição da República de 1988 os concebeu para casos genéricos, nos termos da lei que viria regulamentá-los.

No concernente à convocação de plebiscitos e referendos, a teor do art. 49, inciso XV da Constituição da República de 1988, a competência é do Congresso Nacional. Desse modo,

\footnotetext{
${ }^{218}$ SILVA, Daniela Romanelli da. Democracia e direitos políticos. cit. p. 199.
} 
o texto adotou a forma controlada de convocação (pelo governo), sem, contudo, abrir a possibilidade de convocação não controlada (através de iniciativa popular) ${ }^{219}$.

Parece contraditório ao próprio princípio da democracia semidireta, que institutos de participação popular só sejam convocados pelos órgãos de representação. Ora, se o objetivo de tais instrumentos é a flexibilização da democracia representativa, ao deixar a competência para estabelecer em quais assuntos o povo poderá se pronunciar nas mãos de deputados e senadores, há um contrassenso. Nas palavras de Arend Liphart: “o referendo sozinho é um passo modesto rumo à democracia direta, mas combinado com a iniciativa popular, torna-se um passo gigante",220.

No entanto, em sentido oposto à previsão constitucional federal e visando dar maior extensão à participação popular, alguns estados brasileiros, por meio de suas constituições, atribuíram à população a competência para convocar plebiscitos e referendos: Mato Grosso (art. $6^{\circ}$, I); Rio de Janeiro (art. 120) e São Paulo (Art. 24, § $3^{\circ}$, números 2 e 3).

Voltando ao nível federal, mais de dez anos após a promulgação da Constituição da República de 1988, adveio a lei à qual se refere o art. 14: “A soberania popular será exercida pelo sufrágio universal e pelo voto direto e secreto, com valor igual para todos, e, nos termos da lei , mediante: I - plebiscito; II - referendo; [...]”. A Lei n. ${ }^{\circ}$ 9.709/1988 regulamenta o dispositivo constitucional, disciplinando os institutos.

Assim, prevê a legislação ordinária que referendos e plebiscitos "são consultas formuladas ao povo para que delibere sobre matéria de acentuada relevância, de natureza constitucional, legislativa ou administrativa" (art. 2º caput, da Lei n. ${ }^{\circ}$ 9.709/1988).

Como já tratado anteriormente, a lei não fez uma diferenciação entre ambos os institutos em razão da matéria, tendo adotado somente o critério temporal de distinção: referendo anteriormente ao ato legislativo ou administrativo e plebiscito posteriormente a estes (art. $2^{\circ}$, parágrafos $1^{\circ}$ e $2^{\circ}$, da Lei n. ${ }^{\circ} 9.709 / 1988$ ).

A supramencionada lei ordinária reguladora dos mecanismos de participação popular direta não será pormenorizada nesse item, pois, a cada tópico que guarde relação e

\footnotetext{
${ }^{219}$ SMITH, Gordon apud LIJPHART, Arend. Democracies. New Haven/London: Yale University Press, 1984. p. 203.

${ }^{220}$ LIJPHART, Arend. Democracies. cit. p. 200.
} 
importância com os assuntos por ela tratados, haverá menção aos seus dispositivos legais correspondentes.

Ademais, como se verá adiante, a Lei n. ${ }^{\circ}$ 9.709/1988 não é suficiente para o atual estágio democrático, havendo vários projetos de lei e propostas de emendas constitucionais com a finalidade de ampliar, facilitar e melhorar a participação popular direta.

\subsubsection{Temas de consulta obrigatória}

Há temas que pela própria natureza merecem maior atenção. Assim, em alguns países, a aprovação de texto original e de reformas constitucionais são alvos da consulta direta aos cidadãos.

Algumas constituições preveem a necessidade de consulta popular para aprovação de seu respectivo texto e também de suas emendas. É o caso da Suíça, Austrália, Dinamarca, Irlanda e Japão. Historicamente, reporta-se como primeiro caso de referendo constitucional aquele ocorrido em Massachusetts, em 1778, tendo sido baseado na teoria da "soberania popular" e motivado pela visão "pragmática" de que a participação popular direta melhoraria a administração, diminuindo a corrupção. Ademais, contribuiu para o reequilíbrio entre os poderes, e consequentemente inspirou a adoção do referendo obrigatório para reformas constitucionais em quase todos os estados norte-americanos ${ }^{221}$.

Como visto alhures, a Constituição dos Estados Unidos do Brasil de 1937 considerou explicitamente a realização de plebiscito como condição de sua implantação - art. 187. Entretanto, passado o prazo de seis anos (art. 175 c/c art. 80) dado para a sua realização, nenhuma consulta fora realizada. Assim, a Lei Constitucional n. ${ }^{\circ} 9$ de 28 de fevereiro de 1945 excluiu definitivamente a consulta popular por considerar que o Parlamento supriria a consulta "com vantagem" e, ainda, "que, por outro lado, o voto plebiscitário, implicitamente, tolheria ao Parlamento a liberdade de dispor em matéria constitucional" 222.

\footnotetext{
${ }^{221}$ BENEVIDES, Maria Victoria de Mesquita. A cidadania ativa: referendo, plebiscito e iniciativa popular. cit. p. 142.

222 Lei constitucional n. ${ }^{\circ}$, de 28 de fevereiro de 1945. Disponível em: <http://www2.camara.gov.br/legin/fed/leicon/1940-1949/leiconstitucional-9-28-fevereiro-1945-365005publicacaooriginal-1-pl.html>. Acesso: 1 fev. 2012.
} 
Muito tempo após a tentativa de 1937, a Comissão de Sistematização, da Assembleia Constituinte para elaboração do texto de 1988, também tentou implantar o referendo para aprovação popular do texto que estava sendo elaborado. Nesses termos, o constituinte baiano Brandão Monteiro apresentou a emenda de número 2 ao anteprojeto constitucional, dispondo: "Mediante requerimento subscrito por $1 \%$ dos eleitores do País, a Assembleia Nacional Constituinte determinará obrigatoriamente à Justiça Eleitoral a organização de consulta plebiscitária, submetendo a referendo popular artigos, seções, capítulos ou títulos da Nova Constituição"223. Tal iniciativa, embora enaltecida por outros membros da Assembleia ${ }^{224}$, foi rejeitada por 19 votos a $12^{225}$, não tendo sido adotada no texto final, remanescendo mais uma vez a soberania popular no Brasil.

Assim, no atual texto constitucional, do mesmo modo que nas constituições anteriores, desde 1946, o único tema de consulta obrigatória é o plebiscito territorial para nova arregimentação das bases geográficas de estados e municípios. Segundo prescrição dos parágrafos $3^{\circ}$ e $4^{\circ}$ do art. 18, deverão ser consultadas as populações afetadas no caso de criação, fusão, desmembramento e subdivisão de estados e municípios ${ }^{226}$. Assim como no Brasil, em outros países, como Itália $^{227}$ e França ${ }^{228}$, a obrigatoriedade atinge somente as consultas de caráter territorial.

\footnotetext{
${ }^{223} C f$. Ata de Comissões. Comissão de Sistematização. 11 a reunião ordinária, em 6 de agosto de 1987. p. 261. Disponível em: <http://www2.camara.gov.br/atividade-legislativa/legislacao/Constituicoes_Brasileiras/ constituicao-cidada/publicacoes/anais-da-assembleia-nacional-constituinte>. Acesso em: 7 mai. 2012.

${ }^{224}$ Como se percebe do discurso de Oswaldo Lima Filho: "A iniciativa do Sr. Constituinte Brandão Monteiro parece-me válida no seu aspecto teleológico, na sua preocupação de consultar a aspiração que vem das ruas, do povo. Ainda há poucos dias tive a oportunidade de citar no Plenário da Assembléia Nacional Constituinte a lição desse eminente mestre de todos nós, o Professor Paulo Bonavides afirmando que a Constituinte só cumpriria os seus objetivos e o seu mandato se encontrasse forma de expressar a soberania do povo no poder, as aspirações do povo no poder. Ora, é evidente que - isso se tem dito muito aqui - os Srs. Constituintes foram eleitos para elaborar o pacto social, o pacto jurídico-constitucional brasileiro.

[...]

Se somos representantes do povo, se estamos exercendo um mandato popular, nada mais digno que submeter o resultado do nosso trabalho aos nossos mandantes". In: Ata de Comissões. Comissão de Sistematização. 11 reunião ordinária, em 6 de agosto de 1987. pp. 261-262.

${ }^{225}$ In: Ata de Comissões. Comissão de Sistematização. 11 a reunião ordinária, em 6 de agosto de 1987. p. 269.

${ }^{226}$ Trataremos mais do assunto adiante.

${ }^{227}$ Constituição italiana - art. $132-1^{\mathrm{a}}$ parte: Pode-se, com lei constitucional, ouvidos os Conselhos regionais, dispor a fusão entre as Regiões existentes ou a criação de novas Regiões com um mínimo de um milhão de habitantes, quando solicitado por tantas câmaras municipais que representem pelo menos um terço da população interessada, e a proposta seja aprovada por referendo, por maioria da referida população. $2^{\mathrm{a}}$ parte: Pode-se, com a aprovação da maioria da população da Província ou das Províncias interessadas e do Município ou Municípios interessados expresso mediante referendo e com lei da República, ouvidos os Conselhos regionais, para permitir que as Províncias e Municípios que tenham solicitado, sejam destacados de uma região e agregados a outra. (traduzi). Disponível em: <http://www.governo.it/Governo/Costituzione/2_titolo5.html>. Acesso em: 12 mai. 2012.
} 
Além desse tema, o outro ponto específico que mereceu a obrigatoriedade da deliberação popular foi, em 1993, a realização de consulta plebiscitária para a escolha da forma e do sistema de governo, conforme art. $2^{\circ}$ do Ato das Disposições Constitucionais Transitórias. Essa consulta mereceu ser submetida à população, pois se considerava pendente desde o Decreto n. ${ }^{\circ} 1$, de 1889 , instituidor da forma republicana de governo ${ }^{229}$.

É certo que muitas outras questões, objeto de divergência entre os constituintes, poderiam ter sido submetidas à consulta direta, não quaisquer questões, é claro, mas aquelas que houvessem provocado uma pronunciada divisão de ideias e que tivessem recebido votação contrária significativa ${ }^{230}$.

O constituinte mineiro Virgílio Guimarães chegou a apresentar a Resolução n. ${ }^{\circ} 15$, de 1987, pretendendo apresentar à população até dez temas controvertidos na Assembleia. Assim, pretendia que questões constitucionais polêmicas fossem decididas diretamente pelo povo. Para tanto bastaria colher assinaturas de cinquenta e seis membros da Assembleia para que fosse realizado plebiscito ou mesmo referendo, não se atendo tanto à acepção técnica dos termos. Todavia, por falta de quórum, o projeto foi arquivado com parecer contrário do relator na Comissão de Sistematização ${ }^{231}$.

Analisando-se a experiência internacional, tem-se na Suíça a obrigatoriedade do referendo para questões constitucionais, nos casos de revisão do texto, filiação a organizações de segurança coletiva ou supranacionais, leis federais urgentes e sem embasamento na Constituição, além de todas as iniciativas populares com fins de revisão constitucional total ou parcial, se rejeitadas pela Assembleia Federal ${ }^{232}$.

\footnotetext{
${ }^{228}$ Constituição francesa - art. 53 - $3^{\text {a }}$ parte: Nenhuma cessão, troca ou adição de território é válida sem o consentimento das populações interessadas. (traduzi). Disponível em: <http://www.assembleenationale.fr/connaissance/constitution.asp>. Acesso em: 12 mai. 2012.

${ }^{229}$ Decreto n. ${ }^{\circ} 1$, de 15 de novembro de 1889 - Art. $7^{\circ}$ : "Sendo a Republica Federativa Brazileira a fórma de governo proclamada, o Governo Provisório não reconhece nem reconhecerá nenhum governo local contrário à fórma republicana, aguardando, como lhe cumpre, o pronunciamento definitivo do voto da nação, livremente expressado pelo suffragio popular. Disponível em: <http://www2.camara.gov.br/legin/fed/decret/18241899/decreto-1-15-novembro-1889-532625-publicacaooriginal-14906-pe.html>. Acesso em 1 fev. 2012.

${ }^{230}$ BENEVIDES, Maria Victoria de Mesquita. A cidadania ativa: referendo, plebiscito e iniciativa popular. cit. p. 144.

${ }^{231}$ In: Ata de Comissões. Comissão de Sistematização. $11^{\mathrm{a}}$ reunião ordinária, em 6 de agosto de 1987. pp. 255321.

${ }^{232}$ Constituição suíça. Art. 140. Disponível em: 〈http://www.admin.ch/ch///rs/101/index.html〉. Acesso em: 10 abr. 2012.
} 
Alguns estados norte-americanos também condicionam a referendo obrigatório questões constitucionais controvertidas, tendo, inclusive, grande participação popular, pois, em alguns casos, atingem grupos sociais específicos ou mesmo interesses locais relevantes ${ }^{233}$.

No tocante às revisões constitucionais, alguns textos obrigam que os eleitores sejam consultados antes de concretizada as alterações. Nesse sentido, a Constituição australiana prevê a consulta popular como parte do processo de alteração constitucional. Assim, entre dois e seis meses após a aprovação por maioria absoluta nas duas Casas do Parlamento, a proposta deve ser submetida, em cada Estado e Território, aos eleitores qualificados para votar na Casa dos Representantes ${ }^{234}$. Da mesma maneira, a Constituição irlandesa preconiza que as emendas ao texto original deverão ser submetidas a referendo popular ${ }^{235}$. Por fim, destaca-se, ainda, a Constituição dinamarquesa, que também coloca a referendo popular as alterações constitucionais, todavia, com uma peculiaridade, pois não é necessária a aprovação da maioria do eleitorado, desde que a maioria tenha se manifestado, de modo que considera-se aprovada a emenda caso pelo menos quarenta por cento dos eleitores tenham sido favoráveis e também tenha recebido o aval do rei ${ }^{236}$.

Além das alterações constitucionais, há outros temas que, pela importância e natureza, deveriam ensejar as consultas diretas. São eles: direitos humanos, políticas públicas de grande impacto ambiental e matérias legislativas que envolvem diretamente interesses corporativos dos parlamentares ${ }^{237}$.

No caso dos direitos humanos, é claro, para ampliá-los, nunca restringi-los e menos ainda extingui-los. Na verdade, a questão se coloca relevante no tocante aos crimes contra os direitos humanos, especialmente os praticados pelas ditaduras sul-americanas. No Brasil, o lobby militar é muito poderoso. Assim, a lei de anistia dos crimes políticos ganhou facilmente

\footnotetext{
${ }^{233}$ BENEVIDES, Maria Victoria de Mesquita. A cidadania ativa: referendo, plebiscito e iniciativa popular. cit. p. 146.

art.

128. Disponível em: <http://www.aph.gov.au/About_Parliament/Senate/Powers_practice_n_procedures/Constitution/chapter8>. Acesso em: 12 mai. 2012.

${ }^{235}$ Constituição irlandesa - art. 47. Disponível em: <http://www.constitution.ie/constitution-of-ireland/ default.asp>. Acesso em: 12 mai. 2012.

236 Constituição dinamarquesa (traduzida para o inglês) - $\$ 88$. Disponível em: <http://www.euo.dk/euo_en/facts/constitution/>. Acesso em: 12 mai. 2012.

${ }^{237}$ BENEVIDES, Maria Victoria de Mesquita. A cidadania ativa: referendo, plebiscito e iniciativa popular. cit. pp. 142 e 149.
} 
a adesão dos parlamentares. Talvez, por ter sido um tema que tanto afetou a liberdade individual do povo, se fosse decidido por ele próprio, o resultado teria sido outro ${ }^{238}$.

Já o tema das políticas públicas também mereceria maior participação popular, pois, são decisões de grande impacto para o povo de maneira abrangente. Um exemplo é a reforma agrária, tema sempre alvo de especulações, porém constantemente adiado das pautas de discussão do Congresso, pois há de se levar em conta que os grandes latifundiários diretamente interessados - embora em minoria numérica, são detentores de poder econômico expressivo, motivo pelo qual acabam conseguindo dos parlamentares decisões que lhes beneficiem em detrimento da população em geral.

Por fim, há de se questionar se matérias que envolvam diretamente o interesse dos parlamentares devam ser submetidas a consultas diretas. Parece que sim, pois, por óbvio, o aumento nos vencimentos, criação de vantagens e privilégios não devem ser deliberados (ao menos não unicamente) pela classe que os aproveitarão, evitando assim a "deliberação em causa própria ${ }^{239}$.

\subsubsection{Obrigatoriedade de comparecimento}

Inicialmente, esclarecemos que voto ou sufrágio (originário do latim sufragìum) significa o direito de escolher em uma eleição. Refere-se tanto à participação direta quanto à indireta do corpo eleitoral (cidadãos) no governo ${ }^{240}$. Nas palavras de José Afonso da Silva: sufrágio é o direito; voto é o exercício desse direito e escrutínio é o modo de seu exercício ${ }^{241}$.

Um dos temas mais polêmicos, especialmente quando se debate a "Reforma Política", é o voto obrigatório no Brasil, pois o parágrafo $1^{\circ}$, inciso I, do art. 14 dispõe: “O alistamento eleitoral e o voto são: I - obrigatórios para os maiores de dezoito anos.” (grifei)

Djalma Pinto explica que, na verdade, a obrigatoriedade diz respeito ao comparecimento na sessão eleitoral e assinatura da folha de votação ${ }^{242}$.

Corroborando essa assertiva, José Afonso da Silva explica que a obrigatoriedade não é no sentido de impor ao eleitor que emita um voto, mas tão-somente que, na seção eleitoral,

\footnotetext{
${ }^{238}$ Ibid. pp. 149-151.

${ }^{239}$ Ibid. p. 154.

${ }^{240}$ BONAVIDES, Paulo. Ciência política. cit. p. 228.

${ }^{241}$ AFONSO DA SILVA, José. Curso de direito constitucional. cit. p. 349.
} 
esse eleitor assine o caderno de votação e deposite a cédula na urna (ou em tempos de urna eletrônica, que o eleitor digite e confirme). Não importa se ele cumpriu seu dever social e político de escolher algum candidato - o voto, propriamente dito - pois se "vota" em branco, conquanto esse eleitor não tenha desempenhado a função instrumental da soberania popular $^{243}$, se desincumbiu da obrigação procedimental eleitoral.

Nesse sentido, também se pronuncia Biscaretti di Ruffia:

Convém ressaltar, [...] que, nos últimos decênios, várias ordenações constitucionais
- ao comprovar um reprovável e vasto abstencionismo no exercício do direito
eleitoral - acabaram por converter tal direito num correlato dever público,
introduzindo o chamado voto obrigatório [...] que não coarta a vontade individual, já
que obriga apenas participar na votação (mesmo votando em branco), sob a ameaça
de uma sanção (exibição do nome, multa, supressão temporária das listas eleitorais,
etc. $)^{244}$.
(grifei)

Aliás, partindo dessa explicação, vê-se que Biscaretti di Ruffia coadunou a natureza de direito e de dever do voto. Para ele, o voto é um direito eleitoral, pois habilita o cidadão para o exercício da função eleitoral, eminentemente pública, consistente na escolha dos representantes do povo. De outro lado, o voto é um dever, decorrente do dever cívico, correspondente ao exercício direto da função eleitoral ${ }^{245}$.

Um dos maiores argumentos a favor da adoção da obrigatoriedade do voto é o receio de que minorias organizadas dominem o cenário político. Pois, se até em países cujas democracias são mais antigas e consolidadas há altos índices de abstenção, quanto mais em nações com uma democracia recente ${ }^{246}$.

Por outro lado, aqueles que defendem a conscientização política - fundamental para o exercício da participação direta - criticam a adoção do voto obrigatório. Para eles, a necessidade do apoio político, com a finalidade de obter votos, aproximaria os políticos dos eleitores, uma vez que seria necessário dar educação política ao povo para convencê-lo a

\footnotetext{
${ }^{242}$ PINTO, Djalma. Direito eleitoral. São Paulo, Atlas, 2003. p.136.

${ }^{243}$ AFONSO DA SILVA, José. Curso de direito constitucional. cit. p. 358.

${ }^{244}$ RUFFIA, Paolo Biscaretti di. Direito constitucional: instituições de direito público. cit. p. 269.

${ }^{245}$ Ibid. pp. 268-270.

${ }^{246}$ CENEVIVA, Walter. Plebiscito: direito e dever. São Paulo: Departamento Editorial da OAB-SP, 1993. p. 23. Entretanto, como se demonstrará mais adiante, esse argumento - domínio de minorias organizadas - não parece muito robusto para manter a obrigatoriedade do voto.
} 
participar das eleições, o que, consequentemente, seria benéfico para a utilização de instrumentos de participação democrática direta.

Deixe-se de lado, entretanto, a discussão sobre obrigatoriedade do voto ou do comparecimento, pois o objetivo nesse momento é analisar se, assim como na escolha de representantes, o voto nos plebiscitos e referendos é também obrigatório.

Tecnicamente o voto nos representantes do povo difere do voto nos plebiscitos e referendos por serem, esses últimos, instrumentos de participação popular direta. Nesses casos não se vai às urnas escolher um candidato que exercerá o poder em nome do povo, mas sim o próprio povo manifesta-se diretamente sobre uma ação governamental a ser implantada ou uma lei já em vigor. Por esse motivo, há quem defenda que a obrigatoriedade a que se refere o inciso I do parágrafo $1^{\circ}$ do art. 14 da Constituição da República de 1988 se aplica apenas ao voto nos representantes, sendo o voto em plebiscitos ou referendos facultativo.

Todavia, diante da hermenêutica da regra constitucional, conclui-se que será também obrigatório o voto em referendos e plebiscitos. Explica-se: o caput do art. 14 dispõe que "A soberania popular será exercida pelo sufrágio universal e pelo voto direto e secreto, com valor igual para todos, e, nos termos da lei, mediante: I - plebiscito; II - referendo; III - iniciativa popular", bem como o inciso I do parágrafo $1^{\circ}$, inciso I: “O alistamento eleitoral e o voto são: I - obrigatórios para os maiores de dezoito anos". Sendo assim, o parágrafo se submete ao caput, motivo pelo qual a obrigatoriedade estende-se aos instrumentos ali referidos. Ainda, segundo o método de interpretação clássico lógico-sistemático, proposto por Savigny, a regra deve ser interpretada à vista de todo o ordenamento ao qual ela pertence, de modo que, se o voto é obrigatório para escolha de representantes, será também na participação direta através de plebiscitos e referendos.

Nesse sentido, é também o entendimento do Tribunal Superior Eleitoral, nos termos das normas que dispuseram sobre a realização do plebiscito de 1993 e referendo de 2005, respectivamente:

Art. $3^{\circ} \mathrm{O}$ voto no plebiscito é obrigatório para maiores de dezoito anos e facultativo para analfabetos, maiores de setenta e maiores de dezesseis, menores de dezoito anos. (Lei n. ${ }^{\circ} 8.624$, de 4 de fevereiro de 1993).

Art. $3^{\circ} \mathrm{O}$ voto é obrigatório para os maiores de dezoito anos e facultativo para os analfabetos, os maiores de setenta anos e os maiores de dezesseis e menores de dezoito anos (CF, art. 14, $\S 1^{\circ}$, I e II). (Resolução TSE n. ${ }^{\circ} 22.036$, de 4 de agosto de 2005). (grifei) 
Desse modo, o eleitor que injustificadamente deixar de comparecer ao pleito em plebiscitos e referendos sofrerá as mesmas consequências da ausência nas eleições para escolha de representantes, quais sejam, multa e demais sanções previstas no art. $7^{\circ}$, do Código Eleitoral $^{247}$ :

\subsubsection{Efeito vinculante}

Ao analisar a questão do efeito vinculante dos instrumentos de participação direta, deve-se, de início, recorrer às lições do Direito Administrativo sobre vinculação.

É comum dizer que os atos políticos, em geral, são discricionários, cabendo ao administrador optar entre as decisões possíveis. Nesse sentido, discricionariedade se oporia à vinculação. Todavia, não parece correto colocar vinculação e discricionariedade como noções antitéticas, uma vez que todo ato tem sempre um grau de vinculação, pois a lei sempre delimita a competência, a forma e a finalidade dos atos administrativos materiais ${ }^{248}$.

Nessa linha, explica Caio Tácito:

Não há, rigorosamente, nenhum ato totalmente vinculado ou totalmente discricionário. Existem matizes de predominância, mais ou menos acentuados, dando relevo à parte livre ou à subordinada da manifestação administrativa. $\mathrm{O}$ equívoco da doutrina clássica estava em considerar o ato administrativo como um

${ }^{247}$ Art. $7^{\circ} \mathrm{O}$ eleitor que deixar de votar e não se justificar perante o juiz eleitoral até 30 (trinta) dias após a realização da eleição, incorrerá na multa de 3 (três) a 10 (dez) por cento sobre o salário-mínimo da região, imposta pelo juiz eleitoral e cobrada na forma prevista no art. 367.

$\S 1^{\circ}$ Sem a prova de que votou na última eleição, pagou a respectiva multa ou de que se justificou devidamente, não poderá o eleitor:

I - inscrever-se em concurso ou prova para cargo ou função pública, investir-se ou empossar-se neles;

II - receber vencimentos, remuneração, salário ou proventos de função ou emprego público, autárquico ou para estatal, bem como fundações governamentais, empresas, institutos e sociedades de qualquer natureza, mantidas ou subvencionadas pelo governo ou que exerçam serviço público delegado, correspondentes ao segundo mês subsequente ao da eleição;

III - participar de concorrência pública ou administrativa da União, dos Estados, dos Territórios, do Distrito Federal ou dos Municípios, ou das respectivas autarquias;

IV - obter empréstimos nas autarquias, sociedades de economia mista, caixas econômicas federais ou estaduais, nos institutos e caixas de previdência social, bem como em qualquer estabelecimento de crédito mantido pelo governo, ou de cuja administração este participe, e com essas entidades celebrar contratos;

V - obter passaporte ou carteira de identidade;

VI - renovar matrícula em estabelecimento de ensino oficial ou fiscalizado pelo governo;

VII - praticar qualquer ato para o qual se exija quitação do serviço militar ou imposto de renda.

${ }^{248}$ MEIRELLES, Hely Lopes. Direito Administrativo Brasileiro. $20^{\mathrm{a}}$ ed. Atual. por Eurico de Andrade Azevedo et al. São Paulo: Malheiros, 1995. p. 102. 
todo indivisível e, sob essa unidade, qualificá-lo em uma ou outra daquelas categorias. Se nos detivermos, porém, na análise de sua criação, poderemos concluir, facilmente, que a vinculação ou a discrição se manifesta no tocante a cada um dos elementos essenciais do ato ${ }^{249}$.

Sendo assim, como fica a atuação governamental diante da vontade povo resultante das consultas referendárias e plebiscitárias? Pode o Congresso revogar uma lei que fora aprovada em um referendo? De outro lado, deve o Estado viabilizar opção política escolhida pelos cidadãos em um plebiscito? Todas essas questões são controversas, especialmente, no concernente à eficácia jurídica dessas consultas, se vinculante ou não.

Em países nos quais se adota o referendo consultivo - aquele que visa obter uma indicação dos anseios populares - a doutrina clássica defende que não há garantias de que haverá deliberações das autoridades no sentido de acatar a decisão popular. Desse modo, não tem efeito vinculante também o plebiscito, para aqueles que o entendem como sinônimo de referendo consultivo ${ }^{250}$.

Cármen Lúcia Antunes Rocha assevera:

O referendum ante legem pode envolver uma simples consulta popular, sem caráter necessariamente vinculante da conduta do Estado à resposta oferecida pelo povo às questões suscitadas. Neste caso, a manifestação do povo constituirá opinião balizadora da postura estatal assumida, ainda que se distancie ela do norte eleito pelos cidadãos, e esclarecedora da legitimidade, ou não, da atuação do Estado $^{251}$.

Embora o ordenamento jurídico brasileiro seja omisso quanto à vinculação ou não das decisões em consultas populares, nos plebiscitos territoriais, quando houver subdivisão, desmembramento ou formação de novos estados (como se verá adiante), é obrigatório consultar as assembleias legislativas estaduais e também a população interessada, por meio de plebiscito.

A Lei n. ${ }^{\circ}$ 9.709, de 1998, que regulamentou os instrumentos de participação direta do art. 14, da CR, é taxativa ao prever: "as respectivas Assembleias Legislativas opinarão, sem caráter vinculativo, sobre a matéria, e fornecerão ao Congresso Nacional os detalhamentos técnicos concernentes aos aspectos administrativos, financeiros, sociais e econômicos da área

\footnotetext{
${ }^{249}$ TÁCITO, Caio. Direito Administrativo. São Paulo: Saraiva, 1975. p. 65.

${ }^{250}$ BENEVIDES, Maria Victoria de Mesquita. A cidadania ativa: referendo, plebiscito e iniciativa popular. cit. pp. 134-135.

${ }^{251}$ ROCHA, Cármen Lúcia Antunes. O referendum e a representação democrática no Brasil. cit. p. 31.
} 
geopolítica afetada" (art. $4^{\circ}, \S 3^{\circ}$ ). Porém, da mesma forma que o texto constitucional, a lei é silente sobre a vinculação da consulta plebiscitária. Todavia, por ser questão da competência do Congresso Nacional, com a sanção do Presidente da República (art. 48, VI, da Constituição da República de 1988), “o Congresso não está vinculado nem ao pronunciamento plebiscitário nem ao das Assembleias, notando-se que, estas não decidem, apenas opinam pela aprovação, rejeição ou simplesmente se abstêm de tomar partido ${ }^{252}$ ".

Faz-se, entretanto, apenas uma observação. Caso seja aprovada em plebiscito uma nova configuração territorial, o governo federal deve analisar a viabilidade (política, geográfica, financeira, econômica) da proposta, não estando, portanto, vinculado à decisão popular. Trata-se, assim, de uma conveniência política indeclinável. Mas, obviamente, caso conclua-se por não seguir o que fora decidido pelo povo, ainda que desnecessária uma motivação, é prestigioso aos princípios da transparência e moralidade pública que se faça uma convincente justificativa. De outro lado, se a resposta popular for contrária à nova configuração territorial, aí sim o governo não pode impor sua vontade, ainda que conveniente do ponto de vista político.

De tal sorte, diante da não vinculação das decisões plebiscitárias, conclui-se também que não há consequências jurídicas a se tomar, caso a autoridade pública não siga o que fora deliberado pelo povo. O direito apenas serve parâmetros à política, mas esta é amparada por uma discricionariedade mista de oportunidade e conveniência, liberta, em alguns casos, como a consulta plebiscitária, de instrumentos jurídicos que possam conformar os anseios populares à atuação governamental ${ }^{253}$.

É certo, porém, que não se consulta o povo à toa, para nada. Há muitos gastos financeiros envolvidos na realização de um referendo ou plebiscito. Além disso, a população espera que sua vontade seja respeitada, pois “uma consulta que só serve para ouvir a opinião

\footnotetext{
${ }^{252}$ AFONSO DA SILVA, José. Curso de direito constitucional. cit. p. 474.

${ }^{253}$ Espera-se ficar claro não haver aqui uma crítica à liberdade política, mas tão somente uma constatação da ausência de instrumentos jurídicos que vinculem a atuação governamental no caso de decisões plebiscitárias. Cf. Celso Ribeiro Bastos: “[...] há que se constatar a pretensão do direito em traçar regras sobre as quais se deve dar o jogo político. Isto não significa, entretanto, que o direito acabe com a política. Esta, é óbvio, continua a existir mesmo debaixo do Estado constitucional. O direito é, na verdade, uma moldura dentro da qual se considera aceitável o jogo político." In: BASTOS, Celso Ribeiro. Curso de direito constitucional. $18^{a}$ ed. São Paulo: Saraiva, 1997. p. 16. Não se olvide, ainda, a posição de Hanna Arendt, para quem a política só pode ser exercida com liberdade. In: ARENDT, Hannah. O que é política? $3^{\mathrm{a}}$ ed. Trad. Reinaldo Guarany. Rio de Janeiro: Bertrand Brasil, 2002. Passim.
} 
do povo é uma aberração. Não se pede ao povo que dê sua opinião sobre qualquer coisa pede-se ao povo para tomar uma decisão ${ }^{254 \text {, }}$

Maria Victoria de Mesquita Benevides explica que, se a decisão não for vinculante, estar-se-á falando, no máximo, de plebiscito, naquele contexto já tratado de plebiscito como uma opção em questões políticos-institucionais anterior ao ato legislativo. Ademais, pondera que se torna difícil contrariar a decisão popular diante de uma ambiguidade que se põe. Se há um alto índice de abstenção, a autoridade queda-se mais constrangida do que apoiada; por outro lado, se há um resultado claramente majoritário, não há respaldo para agir em contrariedade com o que fora escolhido. Conclui a autora que, mesmo nos países onde se aceita o referendo meramente consultivo, o Parlamento se sente moral e politicamente compelido a adotar o resultado obtido em referendo popular ${ }^{255}$.

Há, contudo, legislações que garantem efeito vinculante às consultas. A Constituição Portuguesa é uma delas, embora condicione a vinculação a um quórum mínimo:

Art. 115

1. Os cidadãos eleitores recenseados no território nacional podem ser chamados a pronunciar-se diretamente, a título vinculativo, através de referendo, mediante proposta da Assembleia da República ou do Governo, em matérias das respectivas competências, nos casos e nos termos previstos na Constituição e na lei.

$[\ldots]$

11. O referendo só tem efeito vinculativo quando o número de votantes for superior à metade dos eleitores inscritos no recenseamento ${ }^{256}$.

Essa exigência de quórum mínimo para produção de efeito vinculativo à decisão foi introduzida pela revisão constitucional de 1997 e, para Jorge Miranda, trata-se de "uma espécie de veto conferida aos abstencionistas ${ }^{257,}$.

\footnotetext{
${ }^{254}$ MEYER, Jan apud BENEVIDES, Maria Victoria de Mesquita. A cidadania ativa: referendo, plebiscito e iniciativa popular. cit. p. 135.

${ }^{255}$ BENEVIDES, Maria Victoria de Mesquita. A cidadania ativa: referendo, plebiscito e iniciativa popular. cit. p. 135 .

$\begin{array}{cccc}\text { Constituição } & \text { portuguesa. } & \text { Disponível } & \mathrm{em}: \\ \text { <http://www.parlamento.pt/Legislacao/Paginas/ConstituicaoRepublicaPortuguesa.aspx }>. & \text { Acesso } & \text { em: }\end{array}$ 23 fev. 2012.

${ }^{257}$ MIRANDA, Jorge. O referendo e o plebiscito: experiência portuguesa. In: Revista mexicana de derecho constitucional. Número 19. México: Universidad Nacional Autónoma de Mexico, 2008. Disponível em: <http://www.juridicas.unam.mx/publica/rev/cconst/cont/19/ard/ard6.htm>. Acesso em: 23 fev. 2012.
} 
Provavelmente, devido ao próprio texto constitucional de sua nação, os autores portugueses se posicionam favoravelmente ao caráter vinculante das decisões referendárias. Maria Benedita Malaquias Pires Urbano é peremptória: “os efeitos jurídicos ligados ao referendo são vinculativos, obrigando a Assembleia da República e o Governo ${ }^{258 \text { ". }}$

No mesmo sentido, José Joaquim Gomes Canotilho prepondera que o caráter vinculativo (no termo usado pelo autor) do referendo introduz uma espécie de decisão-regra, objeto de posterior lei ou convenção internacional, de modo que a decisão tomada pelo povo, por meio do referendo, cria uma nova situação normativa, contudo, não produz automaticamente uma nova lei ou ato normativo ${ }^{259}$.

Entre nós, Cármen Lúcia Antunes Rocha considera o referendo vinculante para as decisões políticas:

[...] o referendum vincularia as decisões estatais à resposta oferecida pelo povo, cuja influência no desempenho das atuações do Estado traria três consequências democráticas indisputáveis: a) legitimação das condutas do Estado; b) exercício eficiente e direto da soberania do povo; c) responsabilidade popular pelas opções sufragadas $^{260}$.

Há de se ponderar, contudo, que mesmo em Portugal, onde a lei do referendo prevê prazo de 90 ou 60 dias $^{261}$ para a Assembleia da República ou Governo aprovarem, respectivamente, o tratado internacional ou o ato legislativo decorrente da aprovação referendária, não há meios jurídicos para se fazer cumprir essa exigência. E, ainda que seja possível uma responsabilização política - do presidente contra a Assembleia: veto político, mensagens dirigidas à Assembleia e dissolução da Assembleia; contra o Governo: demissão do presidente - a responsabilização jurídica, na forma de sanção jurídico-constitucional, por se estar negando efetividade a uma norma decorrente da Constituição, ainda assim, não é possível, pois essa responsabilização assemelhar-se-ia à insconstitucionalidade por omissão, a

\footnotetext{
258 URBANO, Maria Benedita Malaquias Pires. O referendo. Perfil histórico-evolutivo do instituto. Configuração jurídica do referendo em Portugal. cit. p. 261.

${ }^{259}$ CANOTILHO, José Joaquim Gomes. Direito constitucional e teoria da Constituição. cit. p. 937.

${ }^{260}$ ROCHA, Cármen Lúcia Antunes. O referendum e a representação democrática no Brasil. cit. p. 36.

261 Art. 241 da Lei n. ${ }^{\circ} 15-\mathrm{A} / 98 \quad-$ Regime jurídico do referendo. Disponível em: <http://www.parlamento.pt/Legislacao/Documents/Legislacao_Anotada/RegimeJuridicoReferendo_Anotado.pdf>. Acesso em: 3 mar. 2012.
} 
qual só prevê controle objetivo dos atos, não atingindo os sujeitos que os deveriam ter $\operatorname{praticados}^{262}$.

No caso da legislação brasileira, como nem há referência nem aos efeitos jurídicos causados pelo descumprimento da vontade popular, menos ainda às consequências que poderiam decorrer desse descumprimento.

\section{$\underline{\text { Renovação das consultas populares }}$}

Finalizado o estudo sobre o efeito vinculante das consultas, passa-se à análise da possibilidade da renovação destas. De acordo com o estudado até agora, nota-se que a legislação pátria é omissa em vários aspectos das consultas populares, assim também o é na questão da possibilidade de renovação dos questionamentos feitos aos eleitores.

Nem a Constituição da República de 1988, nem a Lei n. ${ }^{0}$ 9.709, de 1998, tratam do procedimento a ser adotado caso uma proposta seja rejeitada. Não há previsão sobre a possibilidade de realização de uma nova consulta, qual o lapso que deve decorrer para a próxima consulta, etc.

Os ordenamentos jurídicos de alguns países, no entanto, mencionam regras a serem seguidas nos casos referidos acima. A lei italiana n. ${ }^{\circ} 352$, de 25 de maio de 1970, preconiza que só poderá ser feita nova consulta sobre assunto rejeitado em referendo após o decurso do prazo de cinco anos ${ }^{263}$. Já o Estatuto jurídico do referendo português estabelece como prazo a próxima sessão legislativa, salvo nova eleição da Assembleia da República ou do governo. Essa lei condiciona também, no caso de referendo vinculativo, a não aprovação, por parte da Assembleia, de proposta de lei com o mesmo objeto de consulta rejeitada pela população ${ }^{264}$.

\footnotetext{
262 URBANO, Maria Benedita Malaquias Pires. O referendo. Perfil histórico-evolutivo do instituto. Configuração jurídica do referendo em Portugal. cit. pp. 261-283.

${ }^{263}$ Legge 25 maggio 1970, n. 352. Art. 38: Nel caso che il risultato del referendum sia contrario all'abrogazione di una legge, o di un atto avente forza di legge, o di singole disposizioni di essi, ne e' data notizia e non puo' proporsi richiesta di referendum per l'abrogazione della medesima legge, o atto avente forza di legge, o delle disposizioni suddette, fermo il disposto dell'articolo 31, prima che siano trascorsi cinque anni. Disponível em: <http://www.normattiva.it/uri-res/N2Ls?urn:nir:stato:legge:1970;352\$art45>. Acesso em: 3 mar. 2012.

${ }^{264}$ Lei n. ${ }^{\circ} 15-A / 98$ - Regime jurídico do referendo. Artigo 243. ${ }^{\circ}$ Dever de não agir da Assembleia da República e do Governo: A Assembleia da República ou o Governo não podem aprovar convenção internacional ou acto legislativo correspondentes às perguntas objecto de resposta negativa com eficácia vinculativa, salvo nova eleição da Assembleia da República ou a realização de novo referendo com resposta afirmativa.

Artigo 244. ${ }^{\circ}$ Propostas de referendo objecto de resposta negativa: As propostas de referendo objecto de resposta negativa do eleitorado não podem ser renovadas na mesma sessão legislativa salvo, respectivamente, nova
} 
$\mathrm{Na}$ ausência de lei brasileira específica, qual o prazo para a realização de novo referendo sobre assunto não aprovado em consulta anterior?

Uma alternativa poderia ser a aplicação, por analogia, dos dispositivos constitucionais que tratam da rejeição de proposta de emendas constitucionais, medidas provisórias ou projetos de lei. Desse modo, caso a população seja contrária a uma consulta referendária, novo questionamento só poderia ser feito na próxima sessão legislativa, ou na mesma, se subscrito pela maioria absoluta dos membros do Senado Federal ou Câmara dos Deputados (conforme artigos 60, $\S 5^{\circ} ; 62, \S 10^{\circ}$ e 67, da Constituição da República de 1988).

O único referendo que houve no Brasil teve por objeto a comercialização de armas de fogo (artigo 35, parágrafo $1^{\circ}$, da lei n. ${ }^{\circ} 10.826$ de 22 de dezembro de 2003). Realizado em 23 de outubro de 2005, a maioria das pessoas $\left(63,94 \%^{265}\right)$ disse "não" à proibição da comercialização das armas. Porém, passado alguns anos dessa consulta, especialmente após o episódio conhecido como "massacre de Realengo" - em que um homem armado invadiu uma escola pública no Rio de Janeiro, atirando contra os alunos, deixando mortos e feridos - projetos no Congresso Nacional reabrem a possibilidade da realização de novo referendo.

No Senado Federal tramita o Requerimento da Comissão de Constituição, Justiça e Cidadania, n. ${ }^{\circ} 13$ de $2011^{266}$, de iniciativa do Senador Marcelo Crivella, solicitando a realização de audiência pública, com a finalidade de tratar da questão de segurança nas escolas brasileiras. Já na Câmara dos Deputados, o Requerimento n. ${ }^{\text {o }} 27$ de $2011^{267}$, da Comissão de Segurança Pública e Combate ao Crime Organizado (CSPCCO), de iniciativa da deputada Perpétua Almeida, requer audiência pública para debater a proposta de realização de referendo sobre a proibição do porte de armas.

Ambos os requerimentos foram apresentados logo após a tragédia carioca ocorrida em 7 de abril de 2011. O requerimento do Senado data de 13 de abril e o da Câmara, 14 de abril

eleição da Assembleia da República ou, no caso de a iniciativa ter sido governamental, até à formação de novo governo.
<http://www.parlamento.pt/Legislacao/Documents/Legislacao_Anotada/RegimeJuridicoReferendo_Anotado.pdf>. Acesso em: 3 mar. 2012.

265 Fonte: Tribunal Superior Eleitoral. Disponível em: <http://www.tse.jus.br/eleicoes/plebiscitos-ereferendos/quadro-geral-referendo-2005>. Acesso em: 5 mar. 2012.

266 Disponível em: <http://www.senado.gov.br/atividade/materia/detalhes.asp?p_cod_mate=102240>. Acesso em: 22 jul. 2013.

267 Disponível em: <http://www.camara.gov.br/proposicoesWeb/fichadetramitacao?idProposicao=498568>. Acesso em: 22 jul. 2013. 
de 2011, ou seja, ainda sob a comoção do episódio. É certo, todavia, que o projeto em trâmite no Senado não trata especificamente da realização de referendo, e o da Câmara, embora cuide de proposta referendária, fala em proibição do porte de armas e não da sua comercialização objeto da consulta em 2005.

Nenhuma das duas propostas teve andamento em suas respectivas casas legislativas, mas, ao que parece, diante da ausência de normas sobre a vinculação da resposta obtida em referendo popular e de lapso temporal para renovação de consultas, as comissões terão trabalho ao produzirem o embasamento legal de seus relatórios.

\subsubsection{Plebiscitos e referendos nas Unidades Federativas}

Seguindo, em geral, os parâmetros presentes na Constituição da República de 1988, os Estados-membros elaboraram suas Cartas introduzindo mecanismos de participação popular direta.

\section{Diferenciação dos institutos}

Inicialmente, destaca-se a técnica redacional de algumas unidades federadas em diferenciar as hipóteses de utilização do referendo e do plebiscito, ao contrário da União Federal que não o fez claramente nem na Constituição da República de 1988 e nem na legislação (especialmente Lei n. ${ }^{\circ}$ 9.709/1998).

Os legisladores constitucionais estaduais utilizaram-se da distinção prevista especialmente pelos doutrinadores italianos ${ }^{268}$, aplicando o critério do objeto da deliberação popular: plebiscito para deliberação sobre fatos ou acontecimentos e referendo para atos normativos. Os estados-membros que assim o fizeram são: Amapá (art. $5^{\circ}$-B); Mato Grosso $\left(\operatorname{arts.} 6^{\circ}\right.$ e $7^{\circ}$ ); Pará $\left(\operatorname{art.~} 7^{\circ}\right.$ ); Rio de Janeiro (art. 120) e São Paulo (art. 24, § $3^{\circ}$, itens $2^{\circ}$ e $\left.3^{\circ}\right)^{269}$.

\footnotetext{
${ }^{268}$ Ver item 3.1: GEMMA, Gladio. Verbetes: plebiscito e referendo. In: BOBBIO, Norberto e outros. Diccionário de política. cit. pp. 927 e 1074-1077 e RUFFIA, Paolo Biscaretti di. Direito constitucional: instituições de direito público. cit. pp. 378-379.

${ }^{269}$ Constituição do Estado do Amapá: Art. 5º-B. Através de plebiscito o eleitorado se manifestará, especificamente, sobre fato, medida, decisão política, programa ou obra pública e, pelo referendo, sobre emenda à Constituição, sobre lei e sobre projetos de emenda à Constituição e de lei.
} 


\section{Competência}

As constituições estaduais atribuíram a competência para autorizar referendo e convocar plebiscito às assembleias legislativas, em simetria à competência do Congresso Nacional (art. 49, XV da Constituição da República de 1988): Acre (art. 44, XXX); Amapá (art. 95, XIII); Amazonas (art. 28, XIX); Bahia (art. 71, XXI); Ceará (art. 49, I); Espírito Santo (art. 56, XVII); Goiás (art. 11, XI); Mato Grosso (art. 26, XII); Minas Gerais (art. 32, XXXVIII); Pará (art. 92, XII); Paraíba (art. 54, XX); Paraná (art. 54, XXI); Pernambuco (art. 14, XXV); Piauí (art. 63, XII); Rio de Janeiro (art. 98, XXI); Rio Grande do Norte (art. 35, XII); Rio Grande do Sul (art. 53, XI); Rondônia (art. 29, XXVIII); Santa Catarina (art. 40, II); São Paulo (Art. 20, XVIII); Sergipe (art. 47, XX); e Tocantins (art. 19, XXI).

Em que pese a competência para convocação de consultas populares ter sido atribuída, na maioria dos estados-membros, às Assembleias Legislativas, há previsões constitucionais que a atribuem também à população, desde que atendidos alguns requisitos.

As constituições do Mato Grosso (art. 6 $6^{\circ}$, caput e inciso I) e do Rio de Janeiro (art. 120) possibilitam a convocação de plebiscito desde que requerido por, pelo menos, cinco por cento dos eleitores acerca de questões relevantes para o destino do Estado. O texto matogrossense prevê ainda o preenchimento de alguns requisitos: cinco por cento dos eleitores, distribuídos, no mínimo, por um quinto dos municípios, com, no mínimo, a subscrição de um por cento dos eleitores em cada um.

Constituição do Estado do Mato Grosso: Art. $6^{\circ} \mathrm{O}$ plebiscito é a consulta à população estadual acerca de questão relevante para os destinos do Estado, podendo ser proposto fundamentadamente à Assembléia Legislativa:

Art. $7^{\circ} \mathrm{O}$ referendo popular é condição de eficácia de norma jurídica nos casos previstos em lei complementar.

Constituição do Estado do Pará: Art. $7^{\circ}$. Através de plebiscito, o eleitorado se manifestará, especificamente, sobre fato, medida, decisão política, programa ou obra pública, e, pelo referendo, sobre emenda à Constituição, lei, projetos de emenda à Constituição e de lei, no todo ou em parte.

Constituição do Estado do Rio de Janeiro: Art. 120 - Mediante proposição devidamente fundamentada de dois quintos dos Deputados ou de cinco por cento dos eleitores inscritos no Estado, será submetida a plebiscito popular questão relevante para os destinos do Estado.

Constituição do Estado de São Paulo: Artigo 24 - A iniciativa das leis complementares e ordinárias cabe a qualquer membro ou Comissão da Assembléia Legislativa, ao Governador do Estado, ao Tribunal de Justiça, ao Procurador-Geral de Justiça e aos cidadãos, na forma e nos casos previstos nesta Constituição.

$\S 3^{\circ}$ - O exercício direto da soberania popular realizar-se-á da seguinte forma:

$[\ldots]$

2 - um por cento do eleitorado do Estado poderá requerer à Assembléia Legislativa a realização de referendo sobre lei;

3 - as questões relevantes aos destinos do Estado poderão ser submetidas a plebiscito, quando pelo menos um por cento do eleitorado o requerer ao Tribunal Regional Eleitoral, ouvida a Assembléia Legislativa; 
A Constituição do Estado de São de Paulo exige um quórum menor, apenas um por cento do eleitorado poderá requerer à Assembleia Legislativa a realização de referendo sobre lei (art. $24, \S 3^{\circ}$, item $2^{\circ}$ ) ou de plebiscito sobre questões relevantes ao Tribunal Regional Eleitoral, ouvida a Assembleia Legislativa (art. 24, $\S 3^{\circ}$, item $3^{\circ}$ ).

Há quem diga que essa convocação popular de plebiscito ou referendo seria inconstitucional, uma vez que o texto da Constituição da República de 1988 não admite essa possibilidade expressamente. Todavia, há de se ressaltar o destaque constitucional à soberania e à participação popular, motivo pelo qual deve ser aceita a convocação popular por algumas constituições estaduais ${ }^{270}$.

A crítica que se faz aos textos é que eles não relacionam quais seriam essas questões relevantes, o que, na prática, pode obstar o requerimento popular, pois continuaria a cargo das assembleias legislativas decidir quais são as questões de relevância.

\section{Plebiscito territorial}

De início, cumpre destacar que muitas das desconfianças em relação aos plebiscitos têm origem nos plebiscitos territoriais, como, por exemplo, o plebiscito alemão para anexação da Áustria (1938) e o russo para anexação dos países bálticos (1939). Contudo, considera-se esse tipo de consulta legítima, especialmente nas federações. Essa espécie plebiscitária, como o próprio nome já diz, tem a finalidade de conhecer a vontade da população nas questões territoriais. Na Alemanha, foi utilizada na normalização do território e prevista tanto na Constituição de Weimar quanto na Lei Fundamental Bonn ${ }^{271}$.

Embasada no exemplo alemão, a federação brasileira, desde a Constituição dos Estados Unidos do Brasil de 1946, adotou explicitamente o instituto, a fim sempre de consultar a população diretamente interessada, nos casos de alteração geográfica do território. Destarte, em quase todas as constituições estaduais ${ }^{272}$, o instrumento mais frequente é o

\footnotetext{
${ }^{270}$ AUAD, Denise. Mecanismos de participação popular no Brasil: plebiscito, referendo e iniciativa popular.

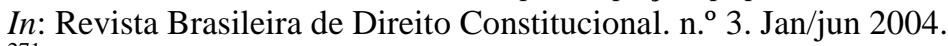

${ }^{271}$ LOEWENSTEIN, Karl. Teoría de la constitución. cit. p. 333.

272 Exceto: Distrito Federal, diante da peculiaridade de seu território, dividido em regiões administrativas (art. $10^{\circ}$ da Lei Orgânica) e Rio Grande do Sul que prevê somente lei estadual para dispor sobre o assunto $\left(\right.$ art. $9^{\circ}$ ). Entretanto, ainda que ausente a previsão de consulta plebiscitária, esta deverá ser realizada, caso haja incorporação, fusão, criação ou desmembramento de munícipio, uma vez ser exigência do texto constitucional federal (poder constituinte originário).
} 
plebiscito consultivo às populações diretamente interessadas na criação, fusão, incorporação e desmembramento de municípios (dispositivo simétrico ao parágrafo $4^{\circ}$ do art. 18 da Constituição da República de 1988): Acre (art. 14); Alagoas (art. 14); Amapá (art. 35, I); Amazonas (art. 119); Bahia (art. 54, I); Ceará (art. 31); Espírito Santo (art. 21); Goiás (art. 83); Maranhão (art. 10); Mato Grosso (art. 176); Mato Grosso do Sul (art.15); Minas Gerais (art. 74, § 1º, ADCT); Pará (art. 83); Paraíba (art. 14); Paraná (art. 19, II); Pernambuco (art. 15, VI); Piauí (art. 30); Rio de Janeiro (art. 357); Rio Grande do Norte (art. 14); Rondônia (art. 42, ADCT); Roraima (art. 17); Santa Catarina (art. 110, § $1^{\circ}$ ); São Paulo (art. 145); Sergipe (art. 12, § 2); e Tocantins (art. 18, ADCT). Algumas constituições reforçam, ainda, o preceito constitucional de unidade territorial do Estado (art. 18, § $3^{\circ}$ da Constituição da República de 1988): Amapá (art. $4^{\circ}$ ); Bahia (art. 5º); e Maranhão (art. $9^{\circ}$ ).

Os parágrafos $3^{\circ}$ e $4^{\circ}$ do art. 18 da Constituição da República de 1988, bem como os dispositivos das constituições estaduais acima, referem-se aos plebiscitos territoriais, sobre nova arregimentação das bases geográficas de estados e municípios.

Prevê o parágrafo $3^{\circ}$ : “Os Estados podem incorporar-se entre si, subdividir-se ou desmembrar-se para se anexarem a outros, ou formarem novos Estados ou Territórios Federais, mediante aprovação da população diretamente interessada, através de plebiscito, e do Congresso Nacional, por lei complementar".

A lei que regulamenta os institutos do art. 14 da Constituição da República de 1988 (Lei n. ${ }^{\circ}$ 9.709/1998) pormenoriza o procedimento, explicando que o plebiscito será convocado, através de decreto legislativo, desde que haja proposta favorável de, no mínimo, um terço dos membros de qualquer das Casas do Congresso Nacional (art. $3^{\circ}$ ). Ademais, preconiza que o plebiscito será realizado na mesma data e horário em cada um dos Estados. Caso o resultado tenha sido favorável à incorporação, subdivisão ou desmembramento, a Casa a qual tenha sido apresentado o projeto de lei complementar deverá ouvir as respectivas Assembleias Legislativas ${ }^{273}$, até mesmo porque dessas audiências serão retirados subsídios administrativos, financeiros, sociais e econômicos para edição da lei regulamentadora da nova área geopolítica, todavia os pareceres do Legislativo estadual não terão efeito vinculante,

Lembra-se, ademais, que Minas Gerais, Rondônia e Tocantins só previram expressamente o plebiscito para os casos de municípios criados pela ocasião de promulgação de suas constituições. Outros Estados também aproveitaram a incumbência dada pelo constituinte originário e dispuseram sobre a consulta plebiscitária a fim de dar legitimidade aos municípios já criados: Alagoas (art. 41, § 5, ADCT); Amapá (art. 4º ADCT); Bahia (arts. 59, 62 e 63, ADCT); Ceará (art. $2^{\circ}, \S 2^{\circ}$, ADCT); e Rio de Janeiro (art. 91, ADCT).

${ }^{273}$ Cf. também art. 48 , VI da Constituição da República. 
podendo o Congresso legislar por si (art. $4^{\circ}$, caput e parágrafos). No tocante ao quórum, a aprovação ou reprovação do plebiscito se dará por maioria simples (art. 10).

Cumpre salientar que tanto os pareceres das assembleias estaduais quanto o próprio resultado do plebiscito são requisitos para a formação de novos estados-membros, todavia ambos não têm caráter vinculativo (art. $4^{\circ}, \S 3^{\circ}$ ), pois é da competência do Congresso Nacional, com a sanção do Presidente da República, dispor sobre as matérias de competência da União, especialmente sobre incorporação, subdivisão e desmembramento de Estados ou Territórios (art. 48, VI, da Constituição da República de 1988), uma vez ser função do Legislativo e do Executivo federais analisar a viabilidade geográfica, econômica, política, financeira dos entes formados. Nas palavras de José Afonso da Silva: “O Congresso não está vinculado nem ao pronunciamento plebiscitário nem ao das Assembleias, notando-se que, estas não decidem, apenas opinam pela aprovação, rejeição ou simplesmente se abstêm de tomar partido ${ }^{274,}$.

Já o plebiscito destinado à criação, à incorporação, à fusão e ao desmembramento de Municípios, será convocado pela Assembleia Legislativa, de conformidade com a legislação federal e estadual (art. 5º da Lei n. ${ }^{\circ}$ 9.709/1998). É que essas alterações territoriais municipais deverão ocorrer dentro dos limites impostos pelo ordenamento. Explica-se: a redação original do art. 18, parágrafo $4^{\circ}$, da Constituição da República de 1988 não contemplava determinação do período de criação de municípios por Lei Complementar Federal e nem a divulgação dos estudos de viabilidade, exigências implementadas apenas pela Emenda Constitucional n. ${ }^{\circ}$ 15, de 1996, tendo, a partir de então, a seguinte redação: “A criação, a incorporação, a fusão e o desmembramento de Municípios, far-se-ão por lei estadual, dentro do período determinado por Lei Complementar Federal, e dependerão de consulta prévia, mediante plebiscito, às populações dos Municípios envolvidos, após divulgação dos Estudos de Viabilidade Municipal, apresentados e publicados na forma da lei.".

$\mathrm{Na}$ Exposição de Motivos da proposta que deu origem à referida emenda constitucional (PEC n. ${ }^{\circ} 41$ de 1991), o deputado subscritor da proposta justifica a necessidade

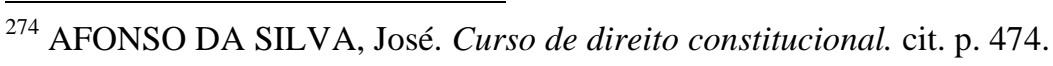


de imposição de restrições que obstassem a criação desenfreada de munícipios com "caráter eleitoreiro" $" 275$.

Ademais, a fim de "regularizar" esses munícipios que, de fato, já haviam sido criados e necessitavam reconhecimento jurídico, o art. 96, do ADCT (incluído pela Emenda Constitucional n. ${ }^{\circ}$ 57, de 2008) dispôs: "Ficam convalidados os atos de criação, fusão, incorporação e desmembramento de Municípios, cuja lei tenha sido publicada até 31 de dezembro de 2006, atendidos os requisitos estabelecidos na legislação do respectivo Estado à época de sua criação".

Resta saber, ainda, quem será consultado nesses plebiscitos. $O$ art. $7^{\circ}$, da Lei n. ${ }^{\circ}$ 9.709/1998, deixa claro que a população interessada é tanto a do território que se pretende desmembrar quanto a do que sofrerá desmembramento; em caso de fusão ou anexação, tanto a população da área que se quer anexar quanto a da que receberá o acréscimo. A vontade popular se aferirá pelo percentual que se manifestar em relação ao total da população consultada.

Desse modo, a população interessada no caso de incorporação é aquela pertencente a todos os estados envolvidos, pois há uma fusão entre dois ou mais estados para formarem um novo, que pode manter algumas características do estado incorporador (topônimo, capital, estrutura administrativa, etc.) ou simplesmente a formação de um ente federado totalmente diferente dos anteriores. Já na ocorrência de subdivisão ou desmembramento, a consulta será à população de um único estado, aquele que será dividido em dois ou mais entes. Ambos os casos, subdivisão e desmembramento, consistem na divisão do território do ente federativo em dois ou mais. Há, todavia, uma peculiaridade no desmembramento: o estado "original"

\footnotetext{
275 Disponível em: <http://imagem.camara.gov.br/dc_20.asp?selCodColecaoCsv=D\&Datain=15/11/1991 \&txpagina=23219\&altura=650\&largura=800> . Acesso em: 10 fev. 2012.

Número de municípios instalados no Brasil desde a década de 1950: 1950: 1.889; 1960: 2.766; 1970: 3.952; 1980: 3.991; 1990: 4.491; 2000: 5.507; 2010: 5.565. Disponível em: <http://seriesestatisticas.ibge.gov.br/series.aspx?vcodigo=CD99\&t=numero-de-unidades-territoriais-nos-censosdemograficos>. Acesso em: 15 fev. 2012.

Da análise desses dados, percebe-se que, na década de 60 até início da de 70, houve aumento do número de municípios, isso porque a Constituição de 1946 previa a repartição da receita tributária do imposto sobre a renda, em partes iguais, independentemente do tamanho geográfico ou populacional (art. $15, \S 4^{\circ}$ ). Durante a década de 70 até início da de 80, com a vigência do regime militar, instituído em 1964, e suas regras rígidas para criação de municípios, vê-se que não houve aumento significativo em seu número. Entretanto, com a Constituição de 1988, e a descentralização nela prevista, novamente nota-se o crescimento na quantidade de municípios, desestimulado, em seguida, nos anos 2000 e 2010, pelas normas constitucionais mencionadas: art. $18, \S 4^{\circ}$, com redação dada pela EC n. ${ }^{\circ} 15$ de 1996 e art. 96 do ADCT, acrescentado pela EC n. ${ }^{\circ} 57$ de 2008.
} 
manterá sua "personalidade primitiva" 276 , perdendo apenas parte de seu território geográfico para os novos entes formados.

$\mathrm{O}$ citado art. $7^{\mathrm{o}}$ da lei, que dispõe qual a população diretamente interessada em caso de desmembramento, foi alvo de uma ação direta de inconstitucionalidade, proposta pela Mesa da Assembleia Legislativa de Goiás, arguindo violação do disposto no parágrafo $3^{\circ}$ do art. 18 da Constituição da República de 1988.

A requerente sustentava que o legislador revisor quis diferenciar o desmembramento ocorrido nos Estados e nos Municípios, pois, por meio da Emenda Constitucional n. ${ }^{\circ} 15$ de 1996, trocou, somente no parágrafo $4^{\circ}$, a expressão “populações diretamente interessadas" por “populações dos Municípios envolvidos”. Sendo assim, para a requerente, a população estadual interessada seria apenas a pertencente à parte desmembrada, ou do novo Estado; situação diversa da subdivisão na qual sim deveriam ser consultadas as populações das regiões as quais se cindiriam e formariam novos Estados.

Todavia, o Supremo Tribunal Federal julgou a improcedência da ação reconhecendo que, assim como nos casos dos Municípios, os desmembramentos ocorridos nos Estados não poderão prescindir de consulta prévia a toda a população ali residente, pois não só aquela da área a ser desmembrada seria atingida, mas também a que perderia parte de seu território ${ }^{277}$.

Malgrado a decisão do Supremo, há quem insista que "população interessada" é só aquela pertencente à área que quer se separar. A pretexto do desenvolvimento geopolítico regional brasileiro utilizam-se do exemplo próspero dos dois últimos estados criados: Mato Grosso do Sul e Tocantins, asseverando que a qualidade de vida daquelas populações melhorou sensivelmente após a mudança territorial. Ademais, corroboram a justificativa sustentando que no último plebiscito realizado - para divisão do Estado do Pará em três regiões: Pará, Carajás e Tapajós - embora tenha vencido a resposta negativa ao desmembramento, as populações das áreas que pretendiam a separação manifestaram-se

\footnotetext{
${ }^{276}$ Para usar o termo cunhado por José Afonso da Silva. In: AFONSO DA SILVA, José. Curso de direito constitucional. cit. p. 474.

277 Ação direta de inconstitucionalidade. Artigo $7^{\circ}$ da Lei 9.709/98. Alegada violação do art. 18, $\S 3^{\circ}$, da Constituição. Desmembramento de estado-membro e município. Plebiscito. Âmbito de consulta. Interpretação da expressão "população diretamente interessada". População da área desmembrada e da área remanescente. Alteração da Emenda Constitucional no 15/96: esclarecimento do âmbito de consulta para o caso de reformulação territorial de municípios. Interpretação sistemática. Aplicação de requisitos análogos para o desmembramento de estados. Ausência de violação dos princípios da soberania popular e da cidadania. Constitucionalidade do dispositivo legal. Improcedência do pedido. AÇÃO DIRETA DE
} 
amplamente favorável a ela, com mais de $90 \%$ de apoio. Por esse motivo, tramita na Câmara dos Deputados o Projeto de Lei n. ${ }^{\circ} 3.453 / 2012^{278}$, que pleiteia deixar mais precisa a redação do art. $7^{\circ}$, da Lei n. ${ }^{\circ}$ 9.709/1998 e também dar nova interpretação à "população diretamente interessada", nos seguintes termos: "Nas consultas plebiscitárias previstas no art. $4^{\circ}$, quando se tratar de desmembramento para criação de novos estados, entende-se como população diretamente interessada a do território que se pretende desmembrar; no caso de fusão ou anexação, tanto a população da área que se quer anexar quanto a da que receberá o acréscimo".

\section{Plebiscito para transferência da capital do Estado elou mudança do topônimo}

Permanecendo na linha de plebiscitos territoriais, ressalta-se haver em algumas constituições estaduais dispositivos que submetem à consulta popular mudanças de suas capitais ou do nome delas.

As constituições dos estados do Espírito Santo (art. $3^{\circ}$ do ADCT) e de Santa Catarina (art. 3 do ADCT), respectivamente, em 15 de novembro de 1990 e 7 de setembro de 1993, previram a consulta de seus eleitores sobre a mudança de suas capitais. Porém, até a presente data, tais consultas não foram realizadas.

Já as constituições do estado do Paraná (art. $5^{\circ}$, parágrafo único) e de São Paulo $\left(\operatorname{art.~} 5^{\circ}\right)$ possibilitam a mudança de suas capitais, mediante lei, porém somente após realização de consulta plebiscitária.

Por fim, há de se destacar que o texto constitucional do estado da Paraíba (art. 82 do ADCT) previu consulta plebiscitária sobre a continuação, ou não, do nome de sua capital, João Pessoa.

INCONSTITUCIONALIDADE - ADI 2650 / DF - DISTRITO FEDERAL. Relator(a): Min. DIAS TOFFOLI. Julgamento: 24/08/2011. Órgão Julgador: Tribunal Pleno. Publicação: DJe-218 17-11-2011.

278 Projeto Lei n. ${ }^{\circ} 3.453 / 2012$. Disponível <http://www.camara.gov.br/proposicoesWeb/fichadetramitacao?idProposicao=537400>. Acesso em: 22 jul. 2013. Cabe lembrar que esse projeto de lei foi apensado, em conjunto com outros semelhantes, ao PL n. 6928/2002 - Estatuto da Democracia Participativa, que já tem parecer favorável da Comissão de Constituição e Justiça. Disponível em: <http://www.camara.gov.br/proposicoesWeb/prop_pareceres_substitutivos_votos?idProposicao=56230>. Acesso em: 22 jul. 2013. 


\section{Consultas sobre impacto ambiental e instalações de usinas nucleares}

Seguindo a tendência de sustentabilidade e de minimização dos impactos ambientais, algumas constituições das unidades federativas facultam a oitiva da população quando da possibilidade de ocorrência de riscos ao meio-ambiente.

A Constituição amazonense, por exemplo, salienta que poderá haver plebiscito com a finalidade de consultar a população quando da instalação de atividades efetiva ou potencialmente causadoras de alterações significativas ao meio ambiente ${ }^{279}$.

No mesmo sentido, a Constituição do Estado do Espírito Santo faculta a cinco por cento dos eleitores do munícipio, atingido pela instalação e operação de obras ou atividades de grande porte e de elevado potencial poluidor, requerer referendo popular ao órgão competente $^{280}$.

Detalhando ainda mais a questão ambiental, alguns textos dispõem sobre consultas plebiscitárias quando da implantação de usinas nucleares ou atividades de pesquisa com material nuclear: Amazonas (art. 235, § 1º); Paraná (art. 209); Rio Grande do Sul (art. 256) e Santa Catarina (art. 185) ${ }^{281}$.

\section{Constituição do Estado do Amazonas:}

Art. $234[\ldots] \S 3^{\circ}$. Na hipótese da instalação de atividades efetivas ou potencialmente causadoras de alterações significativas ao meio ambiente, poderá integrar o processo de licenciamento ou apreciação do estudo de impacto, a consulta, por plebiscito, à comunidade afetada, mediante convocação por um dos Poderes do Estado, nos termos do art. 14, da Constituição da República.

${ }^{280}$ Constituição do Estado do Espírito Santo:

Art. 187 [...] $\S 5^{\circ}$ - Fica assegurado aos cidadãos, na forma da lei, o direito de pleitear referendo popular para decidir sobre a instalação e operação de obras ou atividades de grande porte e de elevado potencial poluidor mediante requerimento ao órgão competente, subscrito por, no mínimo, cinco por cento do eleitorado do Município atingido.

${ }^{281}$ Constituição do Estado do Amazonas:

Art. 235, § $1^{\circ}$. A implantação, no território estadual, de usinas de energia nuclear, instalação de processamento e armazenamento de material radioativo e implantação de unidades de grande porte, geradoras de energia hidroelétrica, respeitadas as reservas estabelecidas em lei e áreas indígenas, de acordo com o disposto no art. 231, da Constituição da República, além da observância das normas e exigências legais e constitucionais, estarão sujeitas ao que estabelece o art. 234, desta Constituição, ao parecer conclusivo do Conselho Estadual de Meio Ambiente, Ciência e Tecnologia e, na hipótese de indicação favorável, aprovação por dois terços dos membros da Assembléia Legislativa, após consulta plebiscitária aos habitantes da área onde se pretende implantar o projeto.

\section{Constituição do Estado do Paraná:}

Art. 209. Observada a legislação federal pertinente, a construção de centrais termoelétricas e hidrelétricas dependerá de projeto técnico de impacto ambiental e aprovação da Assembléia Legislativa; a de centrais termonucleares, desse projeto, dessa aprovação e de consulta plebiscitária.

\section{Constituição do Estado do Rio Grande do Sul:}

Art. 256 - A implantação, no Estado, de instalações industriais para a produção de energia nuclear dependerá de consulta plebiscitária, bem como do atendimento às condições ambientais e urbanísticas exigidas em lei estadual. 
Entretanto, na Ação de Inconstitucionalidade n. ${ }^{\text {o } 329-1, ~ o ~ S u p r e m o ~ T r i b u n a l ~ F e d e r a l ~}$ declarou a inconstitucionalidade do art. 185 da Constituição do Estado de Santa Catarina, por ofensa à competência privativa da União para legislar sobre atividades nucleares ${ }^{282}$..

A relatora Ministra Ellen Gracie ponderou já ter havido, sob a égide da Constituição da República Federativa do Brasil de 1967, julgados no sentido de ser de competência privativa da União a legislação sobre atividades nucleares. Além disso, já há leis sobre a autorização para construção e operação de usinas nucleares (Lei n. ${ }^{\circ}$ 6.189/1974, alterada pela

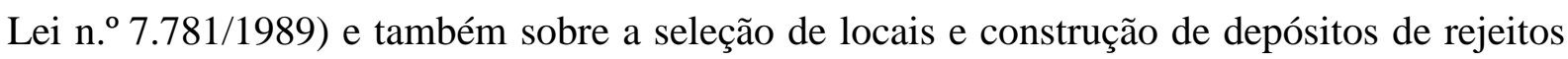
radioativos (Lei n. ${ }^{\circ}$ 10.308/2001), motivo pelo qual, diante da incompetência do constituinte estadual, o dispositivo mencionado foi julgado inconstitucional.

Esse julgamento do Supremo Tribunal Federal mostrou a necessidade da União Federal começar a estudar a possibilidade de levar à consulta da população brasileira a controversa questão da energia nuclear e, principalmente, os impactos ambientais dela decorrentes.

Tramita na Câmara dos Deputados o Projeto de Lei n. ${ }^{\circ}$ 979, de $2011^{283}$, que insere o artigo 10-A à Lei n. ${ }^{\circ} 6.189$, de 1974, propondo que a construção de usina nucleoelétrica só poderá ser feita após a consulta referendária à população do município onde a usina será instalada e também dos municípios limítrofes. Contudo, há uma emenda ao projeto que propõe a substituição do processo de referendo pelo plebiscito:

\section{Constituição do Estado de Santa Catarina:}

Art. 185. A implantação de instalações industriais para produção de energia nuclear, no Estado, dependerá, além do atendimento às condições ambientais e urbanísticas exigidas em lei, de autorização prévia da Assembléia Legislativa, ratificada por plebiscito realizado pela população eleitoral catarinense.

${ }^{282}$ ADI - AÇÃO DIRETA DE INCONSTITUCIONALIDADE 329 / SC - SANTA CATARINA. Relator(a): Min. ELLEN GRACIE. Julgamento: 01/04/2004. Órgão Julgador: Tribunal Pleno. Publicação: DJ 28-05-2004 P 3.

AÇÃO DIRETA DE INCONSTITUCIONALIDADE. CONSTITUIÇÃO DO ESTADO DE SANTA CATARINA. ART. 185. ENERGIA NUCLEAR. ARGÜIÇÃO DE INCONSTITUCIONALIDADE DE PRECEITO DE CONSTITUIÇÃO ESTADUAL, QUE SUBORDINA A CONSTRUÇÃO, NO RESPECTIVO TERRITÓRIO, DE INSTALAÇÕES INDUSTRIAIS PARA PRODUÇÃO DE ENERGIA NUCLEAR À AUTORIZAÇÃO DA ASSEMBLÉIA LEGISLATIVA, RATIFICADA POR PLEBISCITO. ALEGAÇÃO DE OFENSA À COMPETÊNCIA PRIVATIVA DA UNIÃO (CF, ART. 21, XXIII).

1 - Mantida a competência exclusiva da União para legislar sobre atividades nucleares de qualquer natureza $(\mathrm{CF}$, art. 22, XXVI), aplicáveis ao caso os precedentes da Corte produzidos sob a égide da Constituição Federal de 1967.

2 - Ao estabelecer a prévia aprovação da Assembléia Legislativa Estadual, ratificada por plebiscito, como requisito para a implantação de instalações industriais para produção de energia nuclear no Estado, invade a Constituição catarinense a competência legislativa privativa da União

3 - Ação direta de inconstitucionalidade cujo pedido se julga procedente

283 Disponível em: <http://www.camara.gov.br/proposicoesWeb/fichadetramitacao?idProposicao=497929>. Acesso em: 22 jul. 2013. 
Entendemos, no entanto, que o mecanismo de plebiscito é mais apropriado para o caso que o de referendo. Isso porque, com o plebiscito, a consulta ocorre a priori, o que permite que a construção somente de inicie após a aprovação da população. Assim, as medidas corretivas que se fizerem necessárias poderão ser adotadas a tempo e com maior eficácia. A decisão antecipada também poderá evitar a realização de investimentos que poderão ser perdidos em caso de uma eventual recusa dos cidadãos ouvidos em aceitar o funcionamento da usina nuclear ${ }^{284}$.

O projeto de lei traz como justificativa os acidentes nucleares ocorridos em Fukushima e Chernobyl - impactos ambientais decorrentes da instalação usinas nucleares. Contudo, o projeto ressalva os benefícios da instalação de uma usina: geração de postos de trabalho, arrecadação de tributos e desenvolvimento para a região. Destarte, a solução mais democrática seria a realização de um referendo, no qual a população local, por ser o grupo mais apto - uma vez que diretamente interessado - avalia os prós e contras.

Vale lembrar que, recentemente, em junho de 2011, os italianos opinaram em referendo abrogativo sobre energia nuclear, entre outras questões. E, confirmando o que já haviam decidido em 1987, continuaram contrários à instalação de usinas nucleares em seu território $^{285}$.

\section{Consulta popular para desestatização}

Outro assunto presente em algumas constituições estaduais é a possibilidade de consultas populares acerca das desestatizações. Trata-se também de uma solução democrática, uma vez que as empresas estatais ou sociedades de economia mista são constituídas e geridas com dinheiro público.

\footnotetext{
${ }^{284}$ Emenda proposta pelo relator Deputado Paulo Feijóem 10 abr. 2012. Disponível em: <http://www.camara.gov.br/proposicoesWeb/prop_mostrarintegra?codteor=978459\&filename=EMR $+1+\mathrm{CME}+$ $\% 3 \mathrm{D} \% 3 \mathrm{E}+\mathrm{PL}+979 / 2011>$. Acesso em: 22 jul. 2013.

285 Conforme: Decreto-legge 31 marzo 2011, n. 34. Art. 5: (Abrogazione di disposizioni relative alla realizzazione di nuovi impianti nucleari). Disponível em: <http://www.normattiva.it/atto/caricaDettaglioAtto?atto.dataPubblicazioneGazzetta=2011-03-31\&atto.codice Redazionale $=011 \mathrm{G} 0074 \&$ currentPage $=1>$. Acesso em: 5 mar. 2012. E: Decreto del Presidente dela Repubblica 8 luglio 2011, n. 114. Art. 1. 1. In esito al referendum di cui in premessa, i commi 1 e 8 dell'articolo 5 del decretolegge 31 marzo 2011, n. 34, convertito, con modificazioni, dalla legge 26 maggio 2011, n. 75, sono abrogati. Disponível em: <http://www.normattiva.it/atto/caricaDettaglioAtto?atto.dataPubblicazioneGazzetta=2011-0720\&atto.codiceRedazionale=011G0157>. Acesso em: 5 jul. 2013.
} 
Nesses termos, as legislações de Minas Gerais, Rio Grande do Sul e Santa Catarina ${ }^{286}$ somente admitem a alienação ou transferência do controle acionário das empresas estatais com a autorização prévia da população dos respectivos estados, por meio de plebiscito (Rio Grande do Sul) ou referendo (Minas Gerais e Santa Catarina).

Esses textos constitucionais, especialmente o gaúcho, incluído por emenda em 2002, parecem reações políticas às desestatizações promovidas, nesse período, pelo governo federal e alguns estaduais. Lembrando-se que, à época, essas alienações foram alvos de muitas críticas, quer pela necessidade, quer pelo valor das vendas.

\subsubsection{Projetos de alteração da regulamentação}

Tramitam no Congresso Nacional alguns projetos legislativos sobre plebiscitos e referendos. O mais completo deles é Projeto de Lei n. ${ }^{\circ} .718 / 2004^{287}$ da Câmara dos

\section{${ }^{286}$ Constituição do Estado de Minas Gerais}

Art. 14 - Administração pública direta é a que compete a órgão de qualquer dos Poderes do Estado

$\S 17$ - A desestatização de empresa de propriedade do Estado prestadora de serviço público de distribuição de gás canalizado, de geração, transmissão e distribuição de energia elétrica ou de saneamento básico, autorizada nos termos deste artigo, será submetida a referendo popular.

\section{Constituição do Estado do Rio Grande do Sul:}

Art. 22

[...]

$\S 2^{\circ}$ - Especialmente no caso das Sociedades de Economia Mista Banco do Estado do Rio Grande do Sul S.A. e Companhia Riograndense de Saneamento a alienação ou transferência do seu controle acionário, bem como a sua extinção, fusão, incorporação ou cisão dependerá de consulta popular, sob a forma de plebiscito.(Incluído

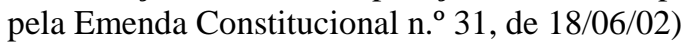

$\S 4^{\circ}$ - A alienação, transferência do controle acionário, cisão, incorporação, fusão ou extinção da Companhia Estadual de Energia Elétrica - CEEE, Companhia Rio-grandense de Mineração - CRM, Companhia de Gás do Estado do Rio Grande do Sul - SULGÁS e Companhia Estadual de Silos e Armazéns - CESA, somente poderão ser realizadas após manifestação favorável da população expressa em consulta plebiscitária. (Incluído pela Emenda Constitucional n. ${ }^{\circ} 33$, de 19/11/02)

$\S 5^{\circ}$ - A alienação ou transferência do controle acionário, bem como a extinção, fusão, incorporação ou cisão da Companhia de Processamento de Dados do Estado do Rio Grande do Sul - PROCERGS -, dependerá de manifestação favorável da população, sob forma de plebiscito. (Incluído pela Emenda Constitucional n. ${ }^{\circ} 47$, de 16/12/04)

\section{Constituição do Estado de Santa Catarina:}

Art. 13

[...]

§ 4ㅇ A alienação ou qualquer transferência do controle acionário da Centrais Elétricas de Santa Catarina S.A. Celesc, sua subsidiária Celesc Distribuição S.A., dependerá obrigatoriamente de autorização legislativa com posterior consulta popular, sob forma de referendo.

§ 5o A alienação superior a quarenta e nove por cento das ações ordinárias da Companhia Catarinense de Águas e Saneamento S.A. - Casan, que implique na troca do controle acionário da Companhia, dependerá obrigatoriamente de autorização legislativa com posterior consulta popular, sob forma de referendo.

287 Disponível em: <http://www.camara.gov.br/proposicoesWeb/fichadetramitacao?idProposicao=274348>. Acesso em: 22 jul. 2013. Há o mesmo projeto de lei no Senado Federal, sob n. ${ }^{\circ}$ 1/2006. Encontra-se arquivado diante do fim da legislatura. Disponível <http://www.senado.gov.br/atividade/materia/detalhes.asp?p_cod_mate=76392>. Acesso em: 22 jul. 2013. 
Deputados, originário da Sugestão n. ${ }^{\circ}$ 84/2004, do Conselho Federal da Ordem dos Advogados do Brasil, a partir de proposta formula pelo jurista Fábio Konder Comparato.

Esse projeto tem por objeto a regulamentação do art. 14, da Constituição da República de 1988, pois considera deficiente a Lei n. ${ }^{\circ} 9.709 / 1998$, principalmente no que tange à ausência de iniciativa popular em matéria de referendos e plebiscitos. Desse modo, seu principal enfoque é a possibilidade de convocação de plebiscito e referendo a partir de iniciativa popular, dentro dos parâmetros da iniciativa popular legislativa. Assim, o art. $9^{\circ}$ assegura a iniciativa nos referendos e o art. $6^{\circ}$ nos plebiscitos que versem sobre: (a) a execução de serviços públicos e programas de ação governamental, nas matérias de ordem econômica e financeira, bem como de ordem social, reguladas nos Títulos VII e VIII da Constituição da República de 1988 e (b) a concessão administrativa de serviços públicos, em qualquer de suas modalidades, bem como a alienação de controle de empresas estatais.

A proposta traz ainda matérias nas quais a consulta popular será obrigatória. No caso de plebiscito para: (a) a mudança de qualificação dos bens públicos de uso comum do povo e dos de uso especial e (b) a alienação, pela União Federal, de jazidas, em lavra ou não, de minerais e dos potenciais de energia hidráulica (art. $3^{\circ}, \S$ único) e referendos sobre: (a) as leis em matéria eleitoral (art. $8^{\circ}, \S$ único) e (b) leis que alteraram ou modificaram projeto decorrente de iniciativa popular (art. 15).

O texto amplia também o rol de tipos legislativos que podem ser submetidos à consulta referendária, incluindo as emendas constitucionais, e, ainda, leis, acordos, pactos, convenções, tratados ou protocolos internacionais de qualquer natureza, ou de atos normativos baixados pelo Poder Executivo (art. $8^{\circ}$, caput).

Ademais, a sugestão assegura que o projeto resultante de iniciativa popular não padecerá de vício de forma, que deverá ser sanado pela Câmara dos Deputados (art. $13, \S 2^{\circ}$ ) e prioridade na tramitação, exceto aqueles em regime de urgência (art. 14).

Vê-se, portanto, que é um projeto bem completo, trazendo, inclusive, a vinculação dos Poderes competentes para a implantação das decisões tomadas em plebiscito (art. $6^{\circ}, \S 3^{\circ}$ ). Todavia, nesse caso, não consigna as consequências, caso isso não seja feito. 
Diante da inovadora e completa sugestão, o projeto obteve parecer favorável e digno de encômios na Comissão de Legislação Participativa. Arquivado em 2007, em razão do fim da legislatura, foi desarquivado em 2011 junto com outros projetos da referida comissão.

Outro projeto, embora bem menos amplo que o anterior, porém de vulto, uma vez que trata de matéria constitucional é a Proposta de Emenda Constitucional n. ${ }^{\circ}$ 26/2006 ${ }^{288}$, originária do Senado Federal. Em suma, traz a proposta de iniciativa popular, nos mesmos moldes da iniciativa popular legislativa (art. 61, § $2^{\circ}$, da Constituição da República de 1988) para a convocação de referendo e plebiscito. Assim, propõe o acréscimo do § 11-A ao art. 14 da Constituição: "Nos casos de autorização de referendo ou de convocação de plebiscito, a iniciativa popular será exercida pela apresentação à Câmara dos Deputados de projeto de decreto legislativo, obedecidas às exigências de subscrição previstas no art. $61, \S 2^{\circ}$ ”.

Justifica-se a proposta, pois embora existam aqueles que defendam ser possível a proposição popular de decreto legislativo com a finalidade de consultas diretas, baseado no art. 61, § 2º , da Constituição da República de 1988, os autores explicam que:

\begin{abstract}
O meio mais seguro de evitar a polêmica nessa matéria, a meu ver, é deixar explícito no texto constitucional aquilo que esses autores consideram implícito: a possibilidade de exercício da iniciativa popular para autorização de referendo e convocação de plebiscito, atendidas as mesmas exigências de subscrição que vigoram para o exercício da iniciativa popular nos casos de projetos de lei. Esse é o objetivo da presente Proposta de Emenda à Constituição ${ }^{289}$.
\end{abstract}

A proposta foi aprovada pela Comissão de Constituição e Justiça, em 21 de outubro de 2010, recebendo apenas reparos de técnica redacional, numerando o parágrafo acrescido para $\S 12$ e dando nova redação ao inciso XV do art. 49, da Constituição da República de 1988: "autorizar referendo e convocar plebiscito, mediante projeto de decreto legislativo apresentado por parlamentar ou cidadãos na forma do $\S 2^{\circ}$ do art. 61". Porém, em 14 de janeiro de 2011, a proposta foi arquivada, motivada pelo fim da legislatura, nos termos do art. 332, do Regimento Interno do Senado Federal ${ }^{290}$.

\footnotetext{
288 Proposta de Emenda Constitucional n. ${ }^{\text {2 26/2006. }}$ Disponível em: <http://www.senado.gov.br/atividade/materia/detalhes.asp?p_cod_mate=78071>. Acesso em: 22 jul. 2013.

289 Proposta de Emenda Constitucional n. ${ }^{\circ}$ 26/2006: Justificativa. Disponível em: <http://legis.senado.leg.br/mateweb/arquivos/mate-pdf/8346.pdf>. Acesso em: 22 jul. 2013.

${ }^{290}$ Regimento Interno do Senado Federal: Art. 332. Ao final da legislatura serão arquivadas todas as proposições em tramitação no Senado, exceto: I - as originárias da Câmara ou por ela revisadas; II - as de autoria de Senadores que permaneçam no exercício de mandato ou que tenham sido reeleitos; III - as apresentadas por Senadores no último ano de mandato; IV - as com parecer favorável das comissões; V - as que tratem de
} 
Mesmo sendo mais uma forma de exercício da soberania popular, esse instrumento, se aprovado, padeceria do mesmo vício da iniciativa popular comum: o povo apresenta, mas é o Congresso que vota a sua aprovação, sem efeitos vinculantes.

Há, ainda, o Projeto de Lei n. ${ }^{\circ} 5.306 / 2009^{291}$ que visa diminuir os gastos com a realização de referendo, fazendo-o coincidir com as eleições estaduais ou municipais. Assim, diminuiriam também os transtornos econômicos indiretos, uma vez que dia de votação é feriado nacional, etc.

\subsubsection{Plebiscitos e referendos realizados: a escassez das consultas diretas}

A Constituição da República de 1988 foi inovadora, pois introduziu no ordenamento pátrio algumas formas de participação direta nunca experimentadas. Em que pese já haver outras previsões em textos anteriores, a verdade é que a única consulta, em nível federal, até o advento da nova Carta, foi realizada em 1963, sobre o sistema de governo.

Seguindo as lições de Robert Dahl, pode-se concluir que, do ponto de vista da sequência histórica, a redemocratização no Brasil, pós-ditadura militar, seguiu o melhor caminho para o desenvolvimento de uma poliarquia, pois houve intensa contestação pública antes do início da participação ${ }^{292}$.

Assim, com as previsões expressas sobre referendo, plebiscito e iniciativa popular, elencados no art. 14, da Constituição da República de 1988, criou-se uma expectativa sobre a participação direta do povo. Fato esse corroborado pela escolha direta do presidente da República, após muitos anos de luta; direito conquistado através da campanha das "Diretas já”.

Contudo, mesmo após a promulgação do texto constitucional, esses institutos têm sido pouco utilizados no Brasil. Certamente não há um único motivo que leve a essa escassez de

matéria de competência exclusiva do Congresso Nacional (Const., art. 49); VI - as que tratem de matéria de competência privativa do Senado Federal (Const., art. 52); VII - pedido de sustação de processo contra Senador em andamento no Supremo Tribunal Federal (Const., art. 53, §§ 3o e 4o, EC n 35/2001). Disponível em: <http://www.senado.gov.br/legislacao/regsf/RegInternoSF_Vol1.pdf >. Acesso em: 25 jul. 2013.

291 Projeto de Lei n. 5.306/2009: Art. $2^{\circ}$ O artigo 11 da Lei ${ }^{\circ}$ 9.709, de 18 de novembro de 1998, passa a vigorar com a seguinte redação: "Art. 11. A data de convocação de referendo ocorrerá sempre na data de $\begin{array}{lllll}\text { eleições } \quad \text { municipais } & \text { ou NR)". }\end{array}$ $<$ http://www.camara.gov.br/proposicoesWeb/fichadetramitacao?idProposicao=436302>. Acesso em: 25 jul. 2013. 
consultas diretas, mas sim uma conjunção de fatores que proporcionam a pouca utilização desses instrumentos.

Certas críticas vêm de longa data, inclusive aqui no Brasil. Na obra intitulada "O referendum legislativo popular ${ }^{293}$,, de 1935, Oswaldo Aranha Bandeira de Mello já apresentava um exame das críticas proferidas contra as consultas populares, e quase todas, ainda hoje, são invocadas por aqueles contrários à participação direta do povo.

Examinando-se os possíveis motivos causadores do entrave na realização de plebiscitos e referendos, destaca-se, em primeiro lugar, o próprio ordenamento jurídico, que limita a convocação das consultas. Como se percebe da leitura do art. 49, da Constituição da República de 1988: "É da competência exclusiva do Congresso Nacional: inciso XV autorizar referendo e convocar plebiscito". Assim, o texto outorgou ao Parlamento a legitimidade exclusiva para esse fim, afastando a competência de outros poderes, ou mesmos dos cidadãos, como acontece em muitos países.

Talvez os constituintes não tenham atribuído a competência para a convocação de consultas por outros poderes, especialmente do Executivo, a fim de evitar as nefastas consultas "populistas" que aconteceram tantas vezes na história. Sobre isso, manifesta-se Maria Victoria Benevides:

Pela tradição francesa, traumatizada pelos plebiscitos napoleônicos, o "plebiscito" é sempre entendido como a degeneração do referendo. Não são mecanismos diferentes; um é a realização mórbida ou saudável do outro. Na dúvida do que pode prevalecer, boa parte dos juristas franceses prefere descartar seu uso prevendo as mais funestas consequências para o regime político.

$[\ldots]$

Do ponto de vista técnico, os equívocos se referem à forma de regulação dos referendos/plebiscitos. A crítica apenas percebe a forma de convocação e/ou autorização pelo poder pessoal (presidente da república, rei, imperador), como se só existisse essa modalidade. Além disso, identifica nos mecanismos de consulta popular, um perigoso jogo de "tudo ou nada".

$[\ldots]$

Do ponto de vista político, o principal equívoco consiste em congelar, para a prática da democracia semidireta, a imagem histórica dos plebiscitos imperiais e ditatoriais. A crítica obscurece a realidade contemporânea dos regimes democráticos com sistemas baseados na participação popular direta, como os Estados Unidos e países da Europa Ocidental. Assim, insiste na aproximação entre democracia direta e totalitarismo, que na lembrança da Revolução Francesa e da experiência

292 DAHL, Robert. A. Poliarquia: participação e oposição. cit. pp. 10 e seg.

${ }^{293}$ MELLO, Oswaldo Aranha Bandeira de. O referendum legislativo popular. cit. pp. 125 e seg. 
napoleônica, quer na crítica da Revolução Russa e à experiência dos sovietes, chegando aos exemplos das ditaduras oriundas da Primeira Guerra Mundial (Itália, Alemanha) ou países latinos (o Brasil do Estado Novo, o Chile de Pinochet) ${ }^{294}$.

Fato é que, dessa forma, quem escolhe os temas e o momento das consultas são os parlamentares, e o que deveria ser instrumento de participação direta da população, com vistas a corrigir certas imperfeições do sistema representativo, volta ao domínio dos representantes, deixando, novamente, o povo à margem das decisões. E, ainda, especialmente no que tange ao referendo, passa a ser apenas uma parte do processo legislativo, pois, depois de todo o debate parlamentar, os cidadãos apenas dirão "sim” ou "não" à implantação de um ato normativo.

Almino Affonso, no entanto, defende que a Lei n. ${ }^{\circ}$ 9.709/1998 cumpriu acertadamente a disposição do art. 49, inciso XV, da Constituição da República de 1988, ao prever iniciativa exclusiva do Congresso Nacional, pois, embora a extensão propositiva seja sedutora do ponto de vista democrático e indutiva de maior participação popular, é certo que o decreto legislativo é o instrumento adequado para regular tais matérias, restando ao povo, apenas o direito de petição comum, no exercício da pressão social, sem, contudo, haver um meio formal para fazê-1o ${ }^{295}$.

No tocante à lei ter de se circunscrever aos ditames constitucionais, porquanto esses dispõem: "É da competência exclusiva do Congresso Nacional: (...) autorizar referendo e convocar plebiscito", de modo a excluir a participação popular na iniciativa das consultas, há controvérsias. O princípio democrático atribui ao povo o poder, podendo esse exercê-lo direta ou indiretamente, não havendo prevalência de um modo sobre o outro. E, embora os representantes do povo tenham um maior número de competências, a Constituição da República de 1988 não prevê que o exercício direto do poder popular deva ser excepcional ${ }^{296}$.

Um dos argumentos ideológicos mais utilizados é a incompetência do povo para entender e opinar sobre os complexos assuntos afetos à democracia moderna. Partindo da premissa de Montesquieu de que o povo não é capaz de gerir a coisa pública por si, necessitando de representantes, ainda hoje se repete essa assertiva para obstar a propagação de instrumentos de participação direta.

\footnotetext{
${ }^{294}$ BENEVIDES, Maria Victoria de Mesquita. A cidadania ativa: referendo, plebiscito e iniciativa popular. cit. pp. $57-58$.

${ }_{295}^{29}$ AFFONSO, Almino Monteiro Álvares. Parecer sobre o projeto de lei n. ${ }^{\circ} 3.589 / 1993$. cit. p. 22354.

${ }^{296}$ SILVA, Daniela Romanelli da. Democracia e direitos políticos. cit. pp. 357-358.
} 
Contudo, não parece acertada essa crítica. Primeiro porque se a incompetência de que se fala é aquela referente ao conhecimento técnico de assuntos complexos, também os representantes não detém tal conhecimento. Nas decisões políticas, são amparados por pareceres advindos das áreas técnicas da Administração. De outro lado, se o povo não tem conhecimento político suficiente é porque a educação é deficitária e só o envolvimento no debate político é que poderá formar uma massa crítica apta a opinar. Talvez, aqui caibam as propostas habermasianas sobre o "agir comunicativo ${ }^{297}$ ", pelo qual a legitimidade do poder do Estado depende diretamente do poder comunicativo da sociedade civil.

Aparece como um desmembramento desse argumento da incapacidade do povo, a maior suscetibilidade dos cidadãos comuns aos grupos de pressão, que atuam junto aos órgãos estatais buscando o atendimento de seus interesses específicos. Não se descarta a pressão, o que se deve contestar é a maior vulnerabilidade do povo. É certo que esses grupos participam de forma incisiva na vida parlamentar, financiando campanhas eleitorais - e depois "cobrando" resultados. Sendo assim, pode haver interesse nas votações referendárias e plebiscitárias, entretanto, não há como se provar que o povo é mais suscetível do que seus representantes.

Outra forma de minimizar os problemas da tecnicidade e complexidade de assuntos, como, por exemplo, o das políticas públicas, é "a separação entre os objetivos de uma política e os meios (programa técnico) para realizá-la”. Os cidadãos devem opinar, assim como faz o Parlamento, nas questões políticas, ou seja, nos objetivos a serem alcançados, pois os meios para sua realização, em um caso ou em outro (democracia direta ou representativa), serão formulados pelos "técnicos" da administração ${ }^{298}$.

Ainda na seara das políticas públicas, revela-se outra vantagem dos mecanismos de participação popular. Às vezes, tão somente a intenção do povo em deliberar sobre um assunto de interesse popular, contudo, de interesse político controverso, pode desencadear o debate parlamentar.

\footnotetext{
${ }^{297}$ Para Jürgen Habermas "o agir comunicativo distingue-se, pois, do estratégico, uma vez que a coordenação bem sucedida da ação não está apoiada na racionalidade teleológica dos planos individuais de ação, mas na força racionalmente motivadora dos atos de entendimento, portanto, numa racionalidade que se manifeste nas condições requeridas para um acordo obtido comunicativamente". In: HABERMAS, Jürgen. Para a reconstrução do materialismo histórico. Trad. Carlos Nelson Coutinho. $2^{\mathrm{a}}$ ed. São Paulo: Brasiliense, 1990. p. 72.

${ }^{298}$ BENEVIDES, Maria Victoria de Mesquita. A cidadania ativa: referendo, plebiscito e iniciativa popular. cit. pp. 83 e 152.
} 
Em termos exemplificativos, pode-se citar a questão do aborto. Mesmo sendo um assunto de relevante interesse popular, não encontra respaldo no poder legislativo por ser um assunto político delicado. O tema não ganha força nos projetos de lei, pois os parlamentares das bancadas religiosas são radicalmente contrários à ideia.

Dessa forma, tal como ocorrera um Portugal, uma saída seria a deliberação popular sobre a legalização do aborto. Além do efetivo debate sobre um tema de seu interesse, uma consulta sobre assuntos polêmicos pode levar a uma cobrança maior por parte dos eleitores sobre os parlamentares, uma vez que seriam exigidas posições mais correspondentes aos anseios populares.

De cunho político, vem outra crítica, o enfraquecimento dos partidos políticos e esvaziamento do Poder Legislativo. A explicação é a possível desautorização dos atos parlamentares, precipuamente dos atos normativos, que, após muitas discussões, ainda teriam de ser referendados pelo povo. Ora, tais atos, à exceção da emenda constitucional, já dependem da sanção ou veto do Poder Executivo, porque não o povo, verdadeiro titular do poder, teria o direito de fazê-lo?

Esse parece um argumento provindo da ideologia oligárquica dos partidos políticos, pois pretendem o monopólio da expressão da vontade popular ${ }^{299}$. Algumas leis são aprovadas para atender interesses de certos grupos e não por serem convenientes aos cidadãos, de modo que, se a lei for referendada pelo povo, deve ser ainda mais prestigiada.

Por outo lado, analisando-se as frentes parlamentares formadas no referendo de 2005, pode-se entender a preocupação com o enfraquecimento dos partidos. Cada agremiação não foi uníssona, permitindo a desagregação de seus parlamentares, que livremente se uniram a uma ou outra frente - "por um Brasil sem armas" ou "pelo direito da legítima defesa",300 - de

\footnotetext{
${ }^{299}$ Ibid. p. 70.

${ }^{300}$ A frente parlamentar "por um Brasil sem armas" era formada, pelos senadores Renan Calheiros (PMDB), Luiz Otávio (PMDB), Gerson Camata (PMDB), César Borges (PFL), Demóstenes Torres (PFL), Tasso Jereissati (PSDB), Arthur Virgílio (PSDB), Aloízio Mercadante (PT), Valmir Amaral (PP), Patrícia Saboya Gomes e Marcelo Crivella (PL); e pelos deputados Raul Jungmann (PPS), Luiz Eduardo Greenhalg (PT), João Paulo Cunha (PT), Maria Lúcia Cardoso (PMDB), Alberto Goldman (PSDB), Jorge Gomes (PSB), ACM Neto (PFL), Fernando Gabeira (PV), João Fontes (PDT), Luiz Antonio de Medeiros (PL) e Renildo Calheiros (PC do B); já a frente parlamentar "pelo direito à legítima defesa" era formada pelos senadores Juvêncio da Fonseca (PSDB) e Osmar Dias (PDT); e pelos deputados federais Alberto Fraga (DEM), Luiz Antonio Fleury (PTB), Abelardo Lupion (DEM), Onyx Lorenzoni (DEM), Coronel Alves (PL), Cabo Júlio (PMDB), Josias Quintal (PSB), Pompeu de Mattos (PDT), Capitão Wayne (PSDB), Josué Bengtson (PTB), Inaldo Leitão (PL), Jair Bolsonaro (PP), Enio Bacci (PDT), Mendes Ribeiro Filho (PMDB), Francisco Appio (PP), Mário Heringer (PDT), Enéas (PRONA), Edmar Moreira (PR), Alceu Collares (PDT), Eliseu Padilha (PMDB), Nelson Marquezelli (PTB) e Wladimir Costa (PMDB). In: Ato da Mesa do Congresso Nacional, de 21 de julho de 2005. Disponível em:
} 
maneira que membros de um mesmo partido político integraram frentes parlamentares diversas.

Mais um argumento político é o desprestígio de plebiscitos e referendos, caso sejam utilizados com muita frequência. Os críticos argumentam que um alto número de consultas levaria à fadiga dos eleitores que não compareceriam em número expressivo, pois não deixariam de lado seus compromissos para opinar, muitas vezes, em assuntos que não lhes interessaria diretamente. Pode-se fazer um paralelo com um universo menor. Geralmente, os condôminos não participam muito das assembleias, só o fazem em quantidade expressiva quando está em pauta assuntos que interessam a todos, por exemplo, a distribuição de vagas de garagem.

Entretanto, analisando-se países pioneiros na utilização de consultas diretas, como Estados Unidos, por exemplo, verifica-se que as eleições envolvendo decisões decorrentes de proposições iniciadas por mecanismos de participação direta atraem um maior número de eleitores, até mesmo alguns considerados “apáticos" ou “alienados" nas eleições regulares ${ }^{301}$.

No caso brasileiro, até pode-se constatar um índice de abstenção mais elevado nas consultas diretas em relação às eleições regulares. No referendo de 2005, o número de abstenção foi de $21,85 \%^{302}$, portanto, maior do que as eleições municipais de $2004(10,33 \%$ em Santa Catarina e 18,11\% no Acre ${ }^{303}$ ) e eleições presidenciais de 2006 (13,88\% no Distrito Federal e 20,84\% no Maranhão ${ }^{304}$ ), mas inferior aos $25,17 \%^{305}$ de abstenções registradas no plebiscito de 1993. Em 2011, o plebiscito territorial no estado do Pará registrou a abstenção de $25,71 \%^{306}$, um índice elevado, se comparado às consultas de 1993 e 2005. Entretanto, pelo

\footnotetext{
<http://www2.camara.gov.br/legin/fed/atomes_sn/2005/atodamesa-35565-21-julho-2005-537881publicacaooriginal-30947-cn.html>. Acesso em: 12 mar. 2012.

${ }^{301}$ MOISÉS, José Álvaro. Cidadania e participação: ensaio sobre o plebiscito, referendo e a iniciativa popular na nova Constituição. cit. p. 75.

302 Fonte: Tribunal Superior Eleitoral. Disponível em: <http://www.tse.jus.br/eleicoes/plebiscitos-ereferendos/quadro-geral-referendo-2005>. Acesso em: 14 mar. 2013.

303 Fonte: Tribunal Superior Eleitoral. Disponível em: <http://www.tse.jus.br/eleicoes/eleicoesanteriores/eleicoes-2004/quadro-geral-eleicoes-2004>. Acesso em: 14 mar. 2013.

304 Fonte: Tribunal Superior Eleitoral. Disponível em: <http://www.tse.jus.br/eleicoes/eleicoesanteriores/eleicoes-2006/quadro-geral>. Acesso em: 14 mar. 2013.

${ }^{305}$ Fonte: Tribunal Superior Eleitoral. Disponível em: <http://www.justicaeleitoral.jus.br/arquivos/plebiscito-de1993>. Acesso em: 14 mar. 2013.

306 Fonte: Tribunal Superior Eleitoral. Disponível em: <http://www.justicaeleitoral.jus.br/arquivos/tre-paresultado-da-votacao-por-estado-tapajos-plebiscito-2011>. Acesso em: 14 mar. 2013.
} 
panorama regional $\left(21,17 \%^{307}\right.$ de abstenções na eleição presidencial de 2010$)$, não foi tão alto assim.

Em 2012 foram realizadas, em alguns municípios, consultas plebiscitárias conjuntamente às eleições municipais. Pôde-se perceber que houve uma melhora significativa no índice de abstenções. Em Rondônia, o plebiscito, que permitiu que parte do município de Nova Brasilândia do Oeste passasse a pertencer a Castanheiras, teve um índice médio de abstenção de $12,52 \%^{308}$. Todavia, nota-se que no município de Castanheiras (que ia receber a nova área), o índice de abstenção foi baixíssimo, apenas 5,17\%. Nesse mesmo Estado, houve ainda o plebiscito sobre a criação do município de Tarilândia, com índice médio de abstenção de $19,02 \%^{309}$.

Ainda em 2012, ocorreu o plebiscito no qual a população de Presidente Kubitschek, no Rio Grande do Norte, optou pela troca do nome do município para Serra Caiada, tendo apenas $13,85 \%{ }^{310}$ de abstenções.

Nota-se, destarte, que a evolução no índice de participação da população nas consultas diretas vem aumentando a cada eleição realizada. Embora haja com poucos dados, uma vez que realizadas poucas consultas, o panorama é favorável contra aqueles que preveem um desprestígio de plebiscitos e referendos.

Por fim, destaca-se o argumento econômico. Nem tanto os gastos envolvidos para a realização das consultas, porque esses podem ser minimizados se os plebiscitos e referendos coincidirem com as eleições regulares ${ }^{311}$, mas os gastos de campanha, pois, obviamente, deve-

\footnotetext{
307 Fonte: Tribunal Superior Eleitoral. Disponível em: <http://www.tse.jus.br/eleicoes/eleicoesanteriores/eleicoes-2010/eleicoes-2010/estatisticas>. Acesso em: 14 mar. 2013.

308 O índice de abstenção em Castanheiras foi 5,17\% (Fonte: Tribunal Regional Eleitoral de Rondônia. Disponível em: <http://www.justicaeleitoral.jus.br/arquivos/tre-ro-resultado-do-plebiscito-em-castanheiras-1010-12>. Acesso em: 24 mar. 2013), já Nova Brasilândia do Oeste alcançou um percentual de 19,87\% (Fonte: Tribunal Regional Eleitoral de Rondônia. Disponível em: <http://www.justicaeleitoral.jus.br/arquivos/tre-roresultado-do-plebiscito-em-nova-brasilandia-10-10-12>. Acesso em: 24 mar. 2013).

${ }^{309}$ Foram envolvidas áreas dos municípios de Jaru e Governador Jorge Teixeira. Abstenção em Jaru: 23,4\% (Fonte: Tribunal Regional Eleitoral de Rondônia. Disponível em: <http://www.justicaeleitoral.jus.br/arquivos/ tre-ro-resultado-do-plebiscito-em-jaru-10-10-12>. Acesso em: 24 mar. 2013), e em Governador Jorge Teixeira: 14,64\% (Fonte: Tribunal Regional Eleitoral de Rondônia. Disponível em: <http://www.justicaeleitoral.jus.br/ arquivos/tre-ro-resultado-do-plebiscito-em-jorge-teixeira-10-10-12>. Acesso em: 4 mar. 2013).

310 Fonte: Tribunal Regional Eleitoral do Rio Grande do Norte. Disponível em: < http://apps.trern.jus.br/frames/eleicoes/eleicoes2012/resultados/relatorios/vereador/votacao_por_municipio/18058.pdf>. Acesso em: 24 mar. 2013.

${ }^{311}$ Nesse sentido já tramita até o Projeto de Lei n. ${ }^{\circ}$ 5.306/2009 que visa diminuir os gastos com a realização de referendo, fazendo-o coincidir com as eleições estaduais ou municipais, minimizando também os transtornos econômicos indiretos, uma vez que dia de votação é feriado nacional, etc.
} 
se imaginar que se houver interesse econômico de algum grupo no resultado da consulta, este certamente investirá a fim de ver seu objetivo realizado.

A fim de garantir a imparcialidade nas campanhas, na Suíça e nos Estados Unidos cabe ao poder executivo elaborar material de esclarecimento, uma espécie de manual - no caso americano sob responsabilidade do Procurador-Geral do Estado - através do qual os eleitores possam buscar informações, principalmente técnicas, sobre cada proposta. Porém justamente nesse ponto advêm críticas daqueles que consideram uma linguagem técnica desestimulante aos eleitores e reforçam a ideia sobre o despreparo dos cidadãos para resolver diretamente questões de alta complexidade ${ }^{312}$.

Na prática, é possível perceber a influência do poder econômico nos resultados de referendos e plebiscitos. Identificado o "foco" da questão que tem mais empatia com o eleitorado, esse será explorado pelo lobby de quem detém maior poder econômico. Destaca-se o referendo norte-americano, de 1985, sobre a proibição de fumar em locais fechados, o “clean indoor". Explorando a argumentação da intervenção indevida do governo ("Big Brother is at it again"), a indústria do cigarro conseguiu explorar o foco correto, ganhando apoio da população, e obtendo êxito, pois não foi naquela oportunidade que se proibira o fumo em locais fechados ${ }^{313}$.

Também no único referendo realizado no Brasil, sobre a comercialização de armas de fogo, foi explorado pela indústria de armas e munições o direito de comprar ou não uma arma e a falhas da segurança pública, pois, provavelmente, o povo brasileiro não se identificaria com propostas de armamento.

A fim de coibir esses problemas de interferência econômica, Maria Victoria de Mesquita Benevides sugere o controle de gastos nos moldes das campanhas eleitorais regulares, garantindo acesso aos meios de comunicação a todos envolvidos no processo, especificação das origens dos recursos, leis que evitem a formação de comitês que escondam grupos de interesse, etc. Para a autora, somente a criação de controles democráticos pode evitar que a desigualdade nos financiamentos acabe desvirtuando a finalidade da participação $\operatorname{direta}^{314}$.

\footnotetext{
${ }^{312}$ BENEVIDES, Maria Victoria de Mesquita. A cidadania ativa: referendo, plebiscito e iniciativa popular. cit. pp. 183-185. ${ }^{313}$ Ibid. p. 186.

${ }^{314}$ Ibid. pp. 191-192.
} 


\section{Consultas populares realizadas no Brasil}

Em consequência dos motivos esposados, percebe-se que a democracia brasileira poucas vezes fez o uso dos instrumentos de participação direta, plebiscito e referendo. Como já destacado anteriormente, um desses instrumentos - o plebiscito - foi utilizado, pela primeira vez, em 1963.

A fim de limitar os poderes do presidente João Goulart, que havia sucedido Jânio Quadros, após sua renúncia, o Congresso Nacional resolveu instituir o parlamentarismo no Brasil. Sendo assim, a Emenda Constitucional n. ${ }^{\circ} 4$, de 2 de setembro de $1961^{315}$, previa em seu art. 22 que se poderia "complementar a organização do sistema parlamentar de governo ora instituído, mediante leis votadas nas duas casas do Congresso Nacional, pela maioria absoluta dos membros".

A emenda trazia, ainda, a possibilidade da realização de plebiscito para a manutenção do parlamentarismo ou retorno ao presidencialismo, "nove meses antes do termo do atual período presidencial" (art. 25 $5^{316}$ ). Destarte, com o mandato de 5 anos (art. $2^{\circ}$ ), a se encerrar em 1966, o plebiscito deveria ser realizado em 1965.

Todavia em 1962, a Lei Complementar n. ${ }^{\circ}{ }^{317}$, que regulamentou a Emenda Constitucional n. ${ }^{\circ}$, de 1961, além de antecipar a realização da consulta para janeiro de 1963, designou-a referendum: “Art. $2^{\circ}$ A Emenda Constitucional no 4, de 2 de setembro de 1961, será submetida a ‘referendum’ popular no dia 6 de janeiro de 1963.

Assim, embora a Emenda Constitucional n. ${ }^{\circ} 4$ de 1961 tivesse previsto um plebiscito para a continuação ou não do sistema de governo, a lei que regulamentou o dispositivo denominou-a referendo. E, nessa mesma linha foi a Resolução n. ${ }^{\circ} .136^{318}$ do Tribunal

\footnotetext{
315 Disponível em: <http://www2.camara.gov.br/legin/fed/emecon/1960-1969/emendaconstitucional-4-2setembro-1961-349692-publicacaooriginal-1-pl.html>. Acesso: 1 fev. 2013.

${ }^{316}$ Emenda Constitucional n. ${ }^{\circ}$ 4, de 2 de setembro de 1961: Art. 25. A lei votada nos termos do art. 22 poderá dispor sobre a realização de plebiscito que decida da manutenção do sistema parlamentar ou volta ao sistema presidencial, devendo, em tal hipótese, fazer-se a consulta plebiscitaria nove meses antes do têrmo do atual período presidencial. Disponível em: <http://www2.camara.gov.br/legin/fed/emecon/19601969/emendaconstitucional-4-2-setembro-1961-349692-publicacaooriginal-1-pl.html>. Acesso: 1 fev. 2013.

317 Disponível em: <http://www2.camara.gov.br/legin/fed/leicom/1960-1969/leicomplementar-2-16-setembro1962-541565-publicacaooriginal-46776-pl.html>. Acesso: 1 fev. 2013.

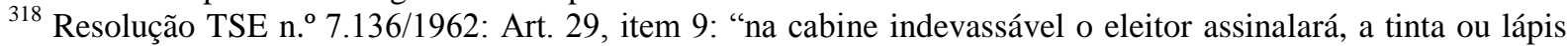
tinta, o quadrilátero correspondente à aprovação (SIM) ou à rejeição (NÃO) do Ato Adicional de 2 de setembro de 1961, e dobrará a cédula na margem esquerda, de modo a resguardar o sigilo do voto, e, em seguida, ao meio,
} 
Superior Eleitoral que continha as "instruções para o 'referendum' de 6 de janeiro de 1963", determinando ainda que os eleitores respondessem "sim" ou "não" à aprovação da Emenda Constitucional n. ${ }^{\circ} 4$, de 2 de setembro de 1961.

O "não" à emenda constitucional e, consequentemente, ao sistema parlamentarista, venceu com 76,98\% ${ }^{319}$. E, em 23 de janeiro de 1963, foi promulgada a Emenda Constitucional n. ${ }^{\circ} 6^{320}$, revogando a Emenda Constitucional n. ${ }^{\circ} 4$, de 1961 e restabelecendo o sistema presidencialista. Dessa maneira, fora cumprido o prazo de 90 dias estabelecido pela Lei Complementar n. ${ }^{\circ}$, de 1962:

Art. $2^{\circ}$ A Emenda Constitucional no 4, de 2 de setembro de 1961, será submetida a "referendum" popular no dia 6 de janeiro de 1963.

$\S 1^{\text {o }}$ Proclamado pelo Superior Tribunal Eleitoral o resultado, o Congresso organizará, dentro do prazo de 90 (noventa) dias, o sistema de governo na base da opção decorrente da consulta.

$\S 2^{\circ}$ Terminado esse prazo, se não estiver promulgada a emenda revisora do parlamentarismo ou instituidora do presidencialismo, continuará em vigor a Emenda Constitucional $\mathrm{n}^{\circ} 4$, de 2 de setembro de 1961, ou voltará a vigorar em sua plenitude, a Constituição Federal de 1946, conforme o resultado da consulta popular.

Outro questionamento levantado é a constitucionalidade da Lei Complementar $n .^{\circ} 2$, de 1962, já que, hierarquicamente, inferior à Emenda Constitucional n. ${ }^{\circ}$ 4, de 1961, poderia prever ato diverso? No caso, referendo, ao invés do plebiscito proposto na emenda?

Ainda assim, há quem defenda que a natureza dessa consulta foi mesmo referendária, uma vez que haveria de se escolher "sim" ou "não" a um ato legislativo, o art. $2^{\circ}$, da Lei Complementar n. ${ }^{\circ}$ 2, de 1961: “A Emenda Constitucional nº 4, de 2 de setembro de 1961, será submetida a 'referendum' popular no dia 6 de janeiro de 1963'.

Marcos Antônio Striquer Soares considera ter havido, na verdade, um "referendo deliberativo", sobre o qual, após a resposta popular, não caberia mais qualquer manifestação de cunho político, deixando aos órgãos apenas a obrigação de "encaminhamento da decisão popular". O autor explica, ainda:

para, afinal, dobrar a parte correspondente ao fecho". Disponível em: <http://www.tse.jus.br/legislacao/pesquisaa-legislacao-eleitoral>. Acesso em: 10 mar. 2013.

319 Fonte: Tribunal Superior Eleitoral. Disponível em: <http://www.tse.jus.br/eleicoes/plebiscitos-ereferendos/referendo-de-1963>. Acesso: 9 mar. 2013.

320 Disponível em: <http://www2.camara.gov.br/legin/fed/emecon/1960-1969/emendaconstitucional-6-23janeiro-1963-363624-publicacaooriginal-1-pl.html>. Acesso: 9 mar. 2013. 
Note-se, também, que não houve equívoco, pois conforme previsto na Emenda Constitucional $\mathrm{n} .^{\circ} 4$, a consulta teria realmente as características de um plebiscito; e na forma como prevista na Lei Complementar $n .^{\circ} 2$, a consulta teria realmente as características de um referendo. Em cada norma, havia a consciência da espécie de consulta que se faria. Na verdade, a sistemática foi aperfeiçoada pela lei posterior ${ }^{321}$.

Entretanto, em razão do objeto - escolha do sistema de governo - e pela anterioridade à atuação governamental, especialmente para aqueles que não diferenciam referendo deliberativo de plebiscito, a consulta de 1963 tem natureza plebiscitária. Assim, define Maria Victoria de Mesquita Benevides: "Nesse caso, como já foi dito em capítulo anterior, pode-se afirmar que houve, efetivamente, uma 'consulta plebiscitária' no sentido de estar em causa a provação a um nome e não há uma proposta"322.

Já na era da redemocratização, durante a última Assembleia Nacional Constituinte, passou-se a discutir um novo plebiscito. Nos termos do art. $2^{\circ}$ do Ato das Disposições Constitucionais Transitórias, haveria a realização de consulta plebiscitária para a escolha da forma e do sistema de governo. É que se considerava pendente tal plebiscito desde o Decreto n. ${ }^{\circ} 1$, de 1889 , instituidor da forma republicana de governo ${ }^{323}$.

Curioso é que a pendência, como colocada, cingia-se ao sistema de governo, se parlamentar ou presidencial, contudo, após muitos debates ${ }^{324}$ e apoiados pela bancada monarquista, liderada pelo constituinte Antônio Henrique Bitencourt Cunha Bueno, foi incluída no plebiscito a consulta sobre a forma de governo.

Argumentavam os constituintes favoráveis a monarquia que, em primeiro lugar, era direito do povo escolher entre as formas republicana ou monárquica, uma vez que a República fora instituída por um "golpe militar", por meio de um decreto. Além disso, defendiam que o Brasil viveu o de maior estabilidade de suas instituições durante os tempos do império.

\footnotetext{
${ }^{321}$ SOARES, Marcos Antônio Striquer. O plebiscito, o referendo e o exercício do poder. cit. p. 99.

322 BENEVIDES, Maria Victoria de Mesquita. A cidadania ativa: referendo, plebiscito e iniciativa popular. cit. p. 119.

${ }^{323}$ Decreto n. ${ }^{\circ} 1$, de 15 de novembro de 1889 - Art. $7^{\text {o. }}$ " "Sendo a Republica Federativa Brazileira a fórma de governo proclamada, o Governo Provisório não reconhece nem reconhecerá nenhum governo local contrário à fórma republicana, aguardando, como lhe cumpre, o pronunciamento definitivo do voto da nação, livremente expressado pelo suffragio popular. Disponível em: <http://www2.camara.gov.br/legin/fed/decret/18241899/decreto-1-15-novembro-1889-532625-publicacaooriginal-14906-pe.html>. Acesso em 1 fev. 2012.

${ }^{324}$ Os principais debates sobre o sistema e forma de governo podem ser encontrados nos relatórios da Comissão da Organização dos Poderes e especialmente nos da Subcomissão do Poder Legislativo (pp. 55-100), dos Anais da Assembleia Nacional Constituinte. Disponível em: <http://www2.camara.gov.br/atividadelegislativa/legislacao/Constituicoes_Brasileiras/constituicao-cidada/publicacoes/anais-da-assembleia-nacionalconstituinte>. Acesso em: 28 fev. 2013.
} 
Sendo assim, a proposta plebiscitária foi incluída no art. $2^{\circ}$ do Ato das Disposições Constitucionais Transitórias. Ressalta-se, apenas, que inicialmente o plebiscito ocorreria em 15 de novembro de $1993^{325}$, porém fora antecipado para o dia 21 de abril do mesmo ano, causando a indignação dos monarquistas que julgaram haver pouco tempo para debates e conscientização da população sobre a importância da consulta.

A Lei n. ${ }^{\circ} 8.604$, de 4 de fevereiro de 1993, regulamentou a realização do plebiscito e, como se sabe, venceu a república presidencialista. A forma republicana obteve $66,26 \%$ dos votos contra $10,25 \%$ da monarquia. Já o presidencialismo venceu com 55,58\% dos votos contra $24,87 \%$ do parlamentarismo ${ }^{326}$.

Apenas muitos anos depois, em 2005, houve novamente, em nível federal, uma nova consulta popular.

A Lei n. ${ }^{\circ} 10.826$ de 22 de dezembro de $2003^{327}$, que dispôs sobre comercialização de armas de fogo, entre outros, conhecida como "Estatuto do desarmamento" previa:

Art. 35. É proibida a comercialização de arma de fogo e munição em todo o território nacional, salvo para as entidades previstas no art. $6^{\underline{0}}$ desta Lei.

$\S 1^{\circ}$ Este dispositivo, para entrar em vigor, dependerá de aprovação mediante referendo popular, a ser realizado em outubro de 2005.

$[\ldots]$

O projeto de lei n. ${ }^{\circ} 1.555 / 2003$, que deu origem ao Estatuto em vigor, intencionava uma maneira de diminuir a violência no Brasil, em especial, o alto número de mortes por armas de fogo. O referendo do parágrafo $1^{\circ}$, do art. 35 , foi um dos itens mais debatidos do projeto, tendo, inclusive, sido retirado em um dos substitutivos ${ }^{328}$, porém retornou na redação final. Uma das discussões travadas a esse respeito foi a natureza da consulta, como sempre muito polêmica, diante da dificuldade em distinguir plebiscito e referendo.

Ao tramitar pela Comissão de Segurança Pública e Combate ao Crime Organizado, o deputado Vicente Cascione defendeu a natureza plebiscitária da consulta, pois prevê o art. 49,

\footnotetext{
${ }^{325} C f$. Ata de Comissões. Comissão de Sistematização. $15^{\mathrm{a}}$ reunião ordinária, em $1^{\circ}$ de setembro de 1987. p. 436. Disponível em: <http://www2.camara.gov.br/atividade-legislativa/legislacao/Constituicoes_Brasileiras/ constituicao-cidada/publicacoes/anais-da-assembleia-nacional-constituinte>. Acesso em: 4 mar. 2013.

${ }^{326}$ Fonte: Tribunal Superior Eleitoral. Disponível em: <http://www.justicaeleitoral.jus.br/arquivos/plebiscito-de1993>. Acesso em: 5 mar. 2013.

${ }^{327}$ Disponível em: <http://www.planalto.gov.br/ccivil_03/leis/2003/L10.826.htm . Acesso em: 10 jul. 2013.

${ }^{328}$ Substitutivo n. ${ }^{\circ} 1$ da Comissão de Segurança Pública e Combate ao Crime Organizado, Violência e Narcotráfico, apresentado em 17 set. 2003.
} 
inciso XV da Constituição da República de 1988: "É da competência exclusiva do Congresso Nacional: [...] autorizar referendo e convocar plebiscito". Dessa maneira, entendia o deputado que só se poderia tratar de referendo se a consulta fosse requerida pelo Poder Executivo e "autorizada" - nos termos do dispositivo constitucional - pelo Congresso Nacional, sendo certo, se tratar, in casu, de plebiscito.

Contudo, no Parecer n. ${ }^{\circ}$, da Comissão de Constituição de Justiça e Redação ${ }^{329}$, o relator, Deputado Luiz Eduardo Greenhalgh, esclareceu que a Constituição da República de 1988, embora regulamente a competência do Congresso Nacional para autorização de referendo, é omissa quanto à sua convocação. Todavia, essa conclusão não está correta, uma vez que a Lei n. ${ }^{\circ}$ 9.709, de 1998, veio suprir essa omissão constitucional, deixando claro que o referendo pode ser convocado, por meio de decreto legislativo, por um terço dos membros do Senado Federal ou da Câmara.

Assim, em 23 de outubro de 2005, foi realizado o referendo, questionando a população: "o comércio de armas de fogo e munição deve ser proibido no Brasil? ${ }^{330 "}$ As pesquisas iniciais, logo após a entrada em vigor do Estatuto, davam conta que cerca de $80 \%$ da população seria favorável à proibição de comercialização de $\operatorname{armas}^{331}$.

Todavia, reputa-se à bem articulada campanha do "não", da frente parlamentar "pela legítima defesa", o sucesso no resultado do referendo. Financiada principalmente pela indústria de armas e munições, a campanha do "não" explorou o direito de comprar ou não uma arma e as falhas da segurança pública no Brasil, já que o povo brasileiro, não muito afeto às armas, provavelmente não se identificaria com propostas de se armar.

Por outro lado, a frente parlamentar "por um Brasil sem armas", liderada por celebridades, não tinha um grande "financiador", sustentava-se apenas na ideologia da paz, divulgada por algumas organizações e institutos. Ademais, o art. 10, da Resolução TSE

\footnotetext{
${ }^{329}$ Disponível em: 〈http://www.camara.gov.br/proposicoesWeb/prop_pareceres_substitutivos_votos?idProposicao=125878> Acesso em: 10 jul. 2013.

${ }^{330}$ Cf. art. $2^{\circ}$, do Decreto Legislativo n. ${ }^{\circ} 780$, de 7 de julho de 2005: "O referendo de que trata este Decreto Legislativo realizar-se-á no primeiro domingo do mês de outubro de 2005, e consistirá na seguinte questão: 'o comércio de armas de fogo e munição deve ser proibido no Brasil?' Parágrafo único. Se a maioria simples do eleitorado nacional se manifestar afirmativamente à questão proposta, a vedação constante do Estatuto do Desarmamento entrará em vigor na data de publicação do resultado do referendo pelo Tribunal Superior Eleitoral." Disponível em: <http://www2.camara.gov.br/legin/fed/decleg/2005/decretolegislativo-780-7-julho2005-537738-publicacaooriginal-30531-pl.html>. Acesso em: 10 jul. 2013.

${ }^{331}$ Cf. Pesquisa IBOPE de $1^{\circ}$ set. 2003. In: Opinião mostra que os brasileiros aprovam o Estatuto do desarmamento. Disponível em: <http://www.ibope.com.br/calandraWeb/servlet/CalandraRedirect?temp
} 
n. ${ }^{\circ} 22.041 / 2005^{332}$, proibia a doação por parte de fundações e organizações que recebessem dinheiro público, entidades de classe e sindicatos e pessoas jurídicas sem fins lucrativos, assim, excluindo, notadamente, grande parte de possíveis doadores à campanha do "sim".

Derrotas e vitórias à parte, esse foi o único referendo de âmbito nacional ocorrido após a vigência da Constituição da República de 1988. Foi vencedora a resposta negativa com $63,94 \%{ }^{333}$, permitindo, destarte, a comercialização das armas.

Algumas outras consultas têm sido realizadas. Destaca-se, em âmbito estadual, o plebiscito territorial para desmembramento do Pará, em 2011, e o referendo sobre o fuso horário adotado no Acre.

O plebiscito territorial, atualmente previsto nos parágrafos $3^{\circ}$ e $4^{\circ}$ do art. 18 , da Constituição da República de 1988, é o mais frequente na legislação brasileira e também o mais conhecido dos eleitores. Não paira qualquer dúvida sobre a necessidade de consultar a população interessada caso pretenda-se a criação de um novo estado ou município. Um dos maiores objetivos da criação de estados federados é o desenvolvimento social do local que, com status de ente federativo, terá maior autonomia e possibilidade de melhor gestão de seus recursos.

Assim, desde 1989, políticos paraenses vinham buscando a realização de consulta plebiscitária com a finalidade de criar o Estado de Carajás, nas regiões sul e sudeste do Pará. Houve pelo menos três tentativas frustradas (1989, 1992 e 2007), que não ensejaram sequer decreto legislativo autorizador da consulta, mas em 2011 finalmente foi possível realizá-la e, aproveitando o ensejo, incluiu-se na pauta a criação do Estado do Tapajós.

Assim, os eleitores de todo o Estado do Pará foram consultados para saber se eram favoráveis à criação do Estado de Carajás e Tapajós ${ }^{334}$. A resposta foi negativa para ambos. $66,60 \%{ }^{335}$ foram contrários à criação do Estado de Carajás e 66,08\% ${ }^{336}$ para Tapajós.

$=5 \&$ proj $=$ PortalIBOPE $\&$ pub $=\mathrm{T} \& \mathrm{db}=\mathrm{caldb} \& \mathrm{comp}=\mathrm{Opini} \% \mathrm{E} 3 \mathrm{o}+\mathrm{P} \% \mathrm{FAblica} \&$ docid $=4 \mathrm{D} 6 \mathrm{~B} 719 \mathrm{CD} 75 \mathrm{E} 550 \mathrm{~F} 8325$ 6EA2006339A5>. Acesso em: 10 jul. 2013.

${ }^{332}$ Resolução TSE n. ${ }^{\circ}$ 22.041/2005: Art. 10. É vedado à frente parlamentar receber, direta ou indiretamente, doação em dinheiro ou estimável em dinheiro, inclusive por meio de publicidade de qualquer espécie, procedente de: I - entidade ou governo estrangeiro; II - órgão da administração pública direta e indireta, federais, estaduais ou municipais ou fundação mantida com recursos provenientes do poder público; III - concessionário ou permissionário de serviço público; IV - entidade de direito privado que receba, na condição de beneficiária, contribuição compulsória em virtude de disposição legal; V - entidade de utilidade pública; VI - entidade de classe ou sindical; VII - pessoa jurídica sem fins lucrativos que receba recursos do exterior. Disponível em: <http://www.tse.jus.br/sadJudLegislacao/pesquisa/actionBRSSearch.do>. Acesso em: 10 mar. 2012. 
Conforme explicado anteriormente, embora o resultado do plebiscito não tenha caráter vinculativo, não parece razoável impor a criação desses estados contrariamente ao que decidiu o eleitorado daquela região.

Outra consulta realizada recentemente foi o referendo sobre o fuso horário do Estado do Acre. A Lei n. ${ }^{\circ} 11.662^{337}$, de 24 de abril de 2008, alterou o Decreto n. ${ }^{\circ}$ 2.784, vigente desde 1913, sobre o fuso horário. A nova lei modificou, para uma hora a mais, os fusos dos Estados do Acre, parte do Amazonas e parte do Pará. As populações afetadas ficaram inconformadas diante da ausência de consulta e esclarecimentos sobre a mudança. As críticas decorreram da falta de debates com os moradores da região e os impactos sobrevindos, ademais, acredita-se que a aprovação da lei foi fruto do lobby de empresários do ramo de telecomunicações, sem real necessidade tecnológica.

Sendo assim, o Decreto Legislativo n. ${ }^{\circ} 900^{338}$, de $1^{\circ}$ de dezembro de 2009 , convocou a população acreana a referendar, ou não, a lei, questionando: "Você é a favor da recente alteração do horário legal promovida no seu Estado?". 56,87\% ${ }^{339}$ da população foram contrários à adoção do novo fuso horário da Lei n. ${ }^{\circ}$ 11.662/2008. Entretanto, devido ao problema da vinculação, a vontade da população ainda não foi atendida. O Tribunal Superior Eleitoral foi consultado sobre a necessidade de edição de novo ato legislativo a fim de dar cumprimento ao que fora decidido nas urnas, mas respondeu que a competência da Corte se encerra com a homologação do resultado ${ }^{340}$. Desse modo, tramita no Senado Federal a

333 Fonte: Tribunal Superior Eleitoral. Disponível em: <http://www.tse.jus.br/eleicoes/plebiscitos-ereferendos/quadro-geral-referendo-2005>. Acesso em: 5 jul. 2013.

${ }^{334} \mathrm{O}$ plebiscito foi convocado, nos termos do inciso XV, do art. 49, da Constituição da República, pelos Decretos Legislativos n. 136 e 137 de 2011. Disponível em: <http://www6.senado.gov.br/legislacao/Lista Normas.action?numero=136\&tipo_norma=DLG\&data=20110526\&link=s $>$. Acesso em: 22 jul. $2013 . \quad \mathrm{O}$ questionamento ao eleitor foi "Você é a favor da divisão do Estado do Pará para a criação do Estado do Tapajós?" e "Você é a favor da divisão do Estado do Pará para a criação do Estado do Carajás?" (art. 50, parágrafo único da Resolução TSE n. ${ }^{\text {o } 23.356 / 2011) .}$

${ }^{335}$ Fonte: Tribunal Regional Eleitoral do Pará. Disponível em: < http://www.justicaeleitoral.jus.br/arquivos/trepa-resultado-geral-da-votacao-carajas-plebiscito-2011>. Acesso em: 22 jul. 2013.

${ }^{336}$ Fonte: Tribunal Regional Eleitoral do Pará. Disponível em: <http://www.justicaeleitoral.jus.br/arquivos/trepa-resultado-da-votacao-por-estado-tapajos-plebiscito-2011>. Acesso em: 22 jul. 2013.

${ }^{337}$ Lei n. $^{\circ} 11.662 / 2008$. Disponível em: <http://www.planalto.gov.br/ccivil_03/_Ato2007-2010/2008/Lei/L11662.htm>. Acesso em: 20 jul. 2013.

${ }^{338}$ Decreto Legislativo n. ${ }^{\circ}$ 900/2009. Disponível em: <http://www2.camara.gov.br/legin/fed/decleg/2009/decreto legislativo-900-1-dezembro-2009-595349-publicacaooriginal-119153-pl.html>. Acesso em: 20 jul. 2013.

${ }^{339}$ Resultado disponível no Acórdão do Tribunal Superior Eleitoral do Processo Administrativo n. ${ }^{\circ}$ 4014-72/AC. Relator: Ministro Marcelo Ribeiro. Disponível em: <http://www.tse.jus.br/sadJudInteiroTeor/pesquisa/actionGetBinary.do?tribunal=TSE\&processoNumero $=40147$ $2 \&$ processoClasse $=$ PA\&decisaoData $=20101214 \&$ decisaoNumero $=\&$ protocolo $=407082010 \&$ noCache $=0.461720$ 3481132175>. Acesso em: 22 jul. 2013.

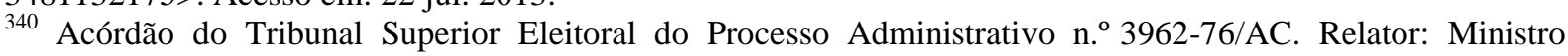
Marcelo

Ribeiro.

Disponível

em: 


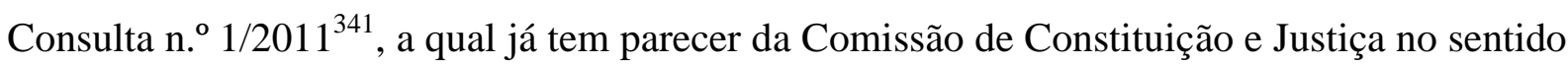
da não vinculação do resultado e, caso se queira atender aos desejos da população, pela necessidade de elaboração de nova lei que substitua a anterior.

Igualmente afetada pela modificação do fuso horário, parte da população dos estados do Amazonas e Pará não foi ouvida para saber sobre sua concordância ou não, motivo pelo qual tramita na Câmara dos Deputados o Projeto de Decreto Legislativo n. ${ }^{\text {o }}$ 2.302/2009 ${ }^{342}$ que visa autorizar um referendo tal qual o ocorrido no Acre.

Por fim, em âmbito municipal ${ }^{343}$, há de se destacar que têm ocorrido algumas consultas, especialmente, as territoriais, mas também algumas que visam à alteração de topônimos.

<http://www.tse.jus.br/sadJudInteiroTeor/pesquisa/actionGetBinary.do?tribunal=TSE\&processoNumero=39627 $6 \&$ processoClasse $=$ PA\&decisaoData $=20101214 \&$ decisaoNumero $=\&$ protocolo $=372722010 \&$ noCache $=0.655804$ 9368844175>. Acesso em: 22 jul. 2013.

341 Consulta do Senado Federal n. ${ }^{\circ} 1 / 2011$. Disponível em: $<\mathrm{http}: / /$ www.senado.gov.br/atividade/materia/detalhes.asp?p_cod_mate=99092\&p_sort=DESC\&p_sort2=A\&p_ $\mathrm{a}=0 \& \mathrm{cmd}=$ sort $>$. Acesso em: 28 jul. 2013.

342 Projeto de Decreto Legislativo n. ${ }^{\circ}$ 2.302/2009. Disponível em: $\langle$ http://www.camara.gov.br/proposicoesWeb/fichadetramitacao?idProposicao=463453〉. Acesso em: 28 jul. 2013.

${ }^{343}$ A título de informação, os referendos e plebiscitos ocorridos em âmbito municipal não são custeados pela União. Assim, como a realização dos mesmos se dá por meio dos Tribunais Regionais Eleitorais, órgão especializado da Justiça Federal, faz-se necessário o repasse de verbas para custeio dessas consultas. Alguns Estados regulamentam a forma desses repasses:

\section{Santa Catarina}

Lei Complementar $\mathrm{n}^{\circ}$ 135, de 11.01.1995 que "dispõe sobre a criação, a incorporação, a fusão e o desmembramento de Municípios (...)" :

"Art. 12 - Determinada e regulamentada a realização do plebiscito, o Tribunal Regional Eleitoral baixará as instruções para sua efetivação, requisitando ao Poder Estadual os recursos financeiros e o material necessários."

Lei Complementar n $\mathrm{n}^{\circ} 225$, de 10.01.2002, que "disciplina a realização de plebiscito e referendo (...)" :

"Art. $5^{\circ}-(\ldots)$

$\S 1^{\circ}$ - Os recursos necessários, inclusive para a divulgação das opiniões favoráveis à aprovação e à denegação, correrão à conta das dotações orçamentárias do Poder ou instituição autônoma responsável pela prática do ato objeto da consulta".

Ceará

Lei Complementar no 29, de 21.02.2002, que "regulamenta a realização de plebiscito e referendo (...)"

"Art. 11 - As despesas legais necessárias para a realização de Plebiscito ou de Referendo pela Justiça Eleitoral correrão por conta das dotações orçamentárias do Poder Legislativo Estadual, e serão repassadas na forma de convênio firmado com o Tribunal Regional Eleitoral, sendo vedado qualquer desembolso para parlamentares, partidos políticos, frentes suprapartidárias, pessoas físicas, jurídicas ou organizações da sociedade civil, com objetivo de propaganda, campanha ou divulgação da consulta popular por qualquer forma."

Rio Grande do Norte

Lei Complementar ${ }^{\circ}$ 102, de 10.01.1992, que "dispõe sobre a criação, fusão e anexação de Municípios, (...) os limites e a toponímia municipais, a criação de distritos (...)" :

“Art. $25-(\ldots)$

Assembléia Legislativa."

$\S 1^{\circ}$ - As despesas com o plebiscito serão custeadas pelo Estado, com as dotações da 
Merece destaque o Estado de Rondônia, onde já foram realizados vários plebiscitos territoriais: em 2009, sobre o desmembramento de área pertencente ao Município de São Miguel do Guaporé e incorporação ao Município de Nova Brasilândia do Oeste; em 2010, sobre a criação ou não do Município de Extrema de Rondônia; em 2012, duas consultas, sobre a criação ou não do Município de Tarilândia, por desmembramento das áreas dos municípios de Jaru e Governador Jorge Teixeira e também sobre o desmembramento de área do município de Nova Brasilândia do Oeste e incorporação ao Município de Castanheiras ${ }^{344}$.

No tocante à alteração de topônimos, destacam-se os plebiscitos realizados, em 2011, no município de Embu, em São Paulo, que passou a se chamar Embu das Artes e, em 2012, na cidade de Presidente Kubitschek, no Rio Grande do Norte, que optou pelo topônimo Serra Caiada.

\section{Acre}

Lei Complementar n 35, de 18.12.1991, que "estabelece requisitos para criação, incorporação, desmembramento e fusão de municípios e a criação e extinção de distritos (...)" :

“Art. 12 - Caberá ao Tribunal Regional Eleitoral regulamentar, mediante resolução, a realização da consulta plebiscitária e fixar-lhe a data, requisitando do Poder Executivo Estadual os recursos financeiros e materiais necessários à sua efetivação."

344 Fonte: Tribunal Regional Eleitoral de Rondônia. Disponível em: <http://www.trero.jus.br/eleicoes/plebiscitos-e-referendos>. Acesso em: 28 jul. 2013. 


\section{CONSIDERAÇÕES FINAIS}

Analisando-se a experiência ateniense, fica clara a diferença do modelo democrático ali adotado (democracia direta) e o vigente hoje em dia (democracia representativa). O que chamamos hoje de democracia representativa, em seu início, pós-revoluções burguesas, era chamado apenas de representatividade, sem a denominação "democracia".

Contudo, é possível perceber que a cidadania tem sido o parâmetro invariável da democracia, ou seja, desde a Grécia antiga, a soberania popular e a obediência às leis são elementos fundamentais dos regimes democráticos.

A democracia, assim como os demais processos, é fruto da evolução histórica e com, o passar do tempo, nota-se o aumento da participação popular. No início, ainda que exercida na sua forma direta, permitia a participação de poucos cidadãos, uma vez que excluía mulheres, estrangeiros e escravos.

Com a adoção do sistema representativo, muitos cidadãos também ficavam excluídos do processo, mesmo da participação indireta, não possuindo sequer o direito de escolher os representantes. Porém, após a II Guerra Mundial, a democracia ganhou status de direito fundamental, e todos os Estados que pretendem autodenominar-se democráticos adotam a participação popular como um de seus pilares.

Entretanto, observa-se que a representação, tal como se apresenta hodiernamente, gera descontentamento no povo. Acredita-se ser a falta de legitimação dos poderes um de seus motivos, em especial, Legislativo e Executivo (já que o Judiciário não é eleito). Em muitos casos, o povo não sente suas necessidades supridas pelas leis vigentes e políticas públicas adotadas, o que acarreta descrença no sistema e nos políticos, levando o povo, cada dia mais, a se afastar das decisões políticas.

A máxima democrática de que "todo poder emana do povo e deve ser exercido em seu benefício" não vem sendo demonstrada no histórico brasileiro, pois, após a eleição, os representantes acabam exercendo o poder em benefício próprio e, pior, muitas vezes contra o anseio popular.

Sob a aparência de Estado Democrático, uma vez que são realizadas eleições periódicas para escolha de representantes, percebe-se apenas a constituição daquilo que Carré 
de Malberg chamou de Estado Legal, pois as normas aprovadas pelos eleitos não atendem os objetivos dos eleitores, bem como aqueles consagrados no artigo $3^{\circ}$ da Constituição da República de 1988, quais sejam: construir uma sociedade livre, justa e solidária; garantir o desenvolvimento nacional; erradicar a pobreza e a marginalização e reduzir as desigualdades sociais e regionais; promover o bem de todos, sem preconceitos de origem, raça, sexo, cor, idade e quaisquer outras formas de discriminação.

Não se nota empenho nem dos representantes e nem dos representados em fazer valer os postulados constitucionais, especialmente, no que concerne à realização do Estado Democrático de Direito. Um Estado de Direito é norteado pelas leis, ou seja, as ações governamentais são fruto da lei que, em última análise, é a expressão da vontade popular. Contudo, não se nega que, ainda assim, não é possível garantir a justiça nas relações sociais. Mas, e o Estado Democrático? Como já se disse antes, o voto periódico não é suficiente para classificar uma democracia.

Percebe-se uma apatia popular, sendo que a atuação democrática restringe-se quase que unicamente ao voto nos representantes, de maneira que, talvez se não houvesse a obrigatoriedade, haveria menos participação.

A consequência dessa apatia é que a falta de participação do povo acaba por afastá-lo, ainda mais, das decisões políticas e do governo e, pior, de certa forma legitima os representantes a, cada vez mais, desconsiderarem o real sentido do interesse popular e atuarem em busca de seus próprios interesses.

Em outras palavras, a relação dos cidadãos com o governo, assim como em todas as relações jurídicas, pressupõe o exercício de direitos e deveres e, quando um dever não é exercido, pode ocasionar a perda do direito. Assim, a não-observância, pelos atores sociais, do dever de participação popular, pode levar à extirpação do respectivo direito.

Há de se ressaltar, inclusive, que, para os representantes do povo que agem desprovidos da ética e do interesse na realização do bem comum, a apatia social é providencial, pois atuarão pensando apenas em seus próprios interesses e despreocupados com atos contestatórios do povo, que assiste a tudo em estado letárgico. Lembre-se, todavia, que em junho de 2013, o movimento social "Passe livre" - que luta pela tarifa zero nos transportes públicos e contra o aumento nas passagens - deu início a uma série de manifestações contra todos os tipos de ações governamentais. De concreto, conseguiu a 
revogação do aumento das passagens em várias cidades, mas nenhuma outra grande reivindicação foi atendida nem decorreram outros movimentos populares de vulto.

Desnecessário lembrar, ainda, que políticos como esses não proporcionam meios tendentes a aumentar a participação popular. Pelo contrário, valem-se da falta de informação e interesse da sociedade para desestimular qualquer iniciativa do povo.

De outro lado, há de se destacar que não se deve responsabilizar apenas o Estado pela falta de participação Cabe também aos cidadãos, como principais agentes sociais, o interesse em fazer valer os direitos fundamentais.

Claro que deve ser incumbido ao Estado o dever de implementar meios que propiciem o fomento da cultura de participação popular e, para tanto, todos os poderes devem estar envolvidos.

O Poder Executivo deve facilitar o diálogo entre a sociedade e o governo, permitindo o acesso dos cidadãos à administração, através dos conselhos municipais, audiências públicas, orçamento participativo, etc. O engajamento do povo na tomada de decisões, ao mesmo tempo que minimiza a falta de legitimidade e eficácia das ações governamentais, também propicia ao cidadão o sentimento de responsabilidade pelas políticas implementadas.

Ao Poder Legislativo cabe o papel de criar um regramento capaz de ampliar e facilitar o acesso aos meios de participação popular.

Por fim, em que pese a ausência de hermenêutica jurídica capaz de considerar as diversas facetas do direito fundamental à participação, o Judiciário deve priorizar, por meio de suas decisões, aquelas ações que buscam inserir a sociedade, ativamente, nas decisões políticas, por exemplo, ação popular, mandado de segurança coletivo, ação civil pública, etc.

Desse modo, parece irreversível a vertente da participação popular em busca da realização do verdadeiro ideal democrático. Contudo, o modelo representativo não tem permitido essa "realização democrática", na qual o poder emanado do povo deveria ser exercido em seu benefício.

Sendo assim, constatadas essas falhas da democracia representativa, busca-se, além da utilização dos instrumentos para o exercício da democracia direta, uma maneira de utilização eficaz dos mesmos. 
Seguindo essa nova tendência, a Constituição da República Federativa do Brasil, promulgada em 1988, implementou concretamente os institutos do referendo e do plebiscito. Embora pareça correta a distinção na conceituação dos instrumentos, diante da dificuldade em fazê-lo, nessa fase conclusiva do estudo, não importa muito o nomem juris dado ao tipo consulta popular, pois o propósito desses está em ouvir diretamente o povo sobre as políticas governamentais a seguir, com o propósito de dar mais legitimidade às decisões.

A fim de regulamentar os instrumentos de participação direta do art. 14, da Constituição da República de 1988, foi promulgada a Lei n. ${ }^{\circ}$ 9.709/1998. Todavia, essa lei não viabilizou uma regulamentação sólida, deixando de lado itens importantes, ainda sem pontuá-los de forma clara e elucidar os procedimentos de maneira objetiva. Por esse motivo, há várias propostas de emenda e projetos de lei em tramitação no Congresso Nacional com a finalidade de suprir as carências legislativas que impedem uma melhor utilização das consultas diretas.

É certo que a melhoria da democracia não depende exclusivamente da legislação. Todavia, é correto dizer também que regramentos sólidos que possam propiciar com maior clareza a delimitação dos assuntos a serem submetidos à apreciação popular, a fim de obter leis e políticas públicas mais legitimas, aumentarão a satisfação dos cidadãos.

Também pode-se afirmar que nesse processo evolutivo da democracia não se pode alijar a representação. Ela é e continuará sendo, pelo menos transitoriamente, o principal pilar democrático. A governabilidade depende de agilidade na tomada de decisões, o que as consultas diretas podem obstaculizar, devido ao tempo necessário entre a informação aos eleitores e o resultado final a se obter. Contudo, isso também não deve ser uma desculpa para excluir os cidadãos das decisões importantes para os rumos do Estado. Não se consegue imaginar ainda a viabilidade de um sistema de democracia exclusivamente direta, ao menos nesse momento, à exceção de alguns cantões suíços. Porém, há de se ter em mente a necessidade de inclusão dos cidadãos nos debates políticos.

O plebiscito e o referendo não são a solução de todos os problemas decorrentes da democracia representativa. Espera-se que, ao longo desse estudo, se tenha deixado claro que é preciso, sim, aumentar a participação popular. Porém, não exclusivamente por meio das consultas diretas, mas usando e aperfeiçoando alguns institutos já presentes na legislação brasileira, como a iniciativa popular, as consultas públicas, orçamentos participativos e, 
talvez, introduzindo alguns instrumentos que vêm dando certo no direito estrangeiro, como o veto popular e as revogações.

Por fim, cumpre lembrar que a inserção de mecanismos de participação direta não têm o condão de transformar a democracia participativa no "modelo ideal". Como já ressaltado várias vezes, a democracia faz parte de um processo de formação histórico que se transformou e irá se transformar muitas vezes - podendo até ser extinto - na busca ao atendimento dos anseios de cada geração. 


\section{REFERÊNCIAS}

AFONSO DA SILVA, José. Curso de direito constitucional positivo. $25^{\mathrm{a}}$ ed. rev. e atual. São Paulo: Malheiros, 2005.

. Poder constituinte e poder popular - estudos sobre a constituição. São Paulo:

Malheiros, 2002.

. O sistema representativo e a democracia semi-direta: democracia participativa.

In: Revista do Advogado da Associação dos Advogados de São Paulo. n. ${ }^{0}$ 73. Nov 2003.

Disponível em <http://www.bibliojuridica.org/libros/1/345/3.pdf>. Acesso em: 18 jun 2011.

AFFONSO, Almino Monteiro Álvares. Parecer sobre o projeto de lei $n .^{o} 3.589 / 1993$. In:

Diário da Câmara dos Deputados, ago. 1996.

ARDANT, Philippe. Institutions politiques et droit constitucionnel. Paris: Librairie générale de droit et de jurisprudence, 1991.

ARENDT, Hannah. O que é política? $3^{\mathrm{a}}$ ed. Trad. Reinaldo Guarany. Rio de Janeiro: Bertrand Brasil, 2002.

ARISTÓTELES. A política. Trad. Nestor Silveira Chaves. 2a ed. rev. Bauru: Edipro, 2009.

AUAD, Denise. Mecanismos de participação popular no Brasil: plebiscito, referendo e iniciativa popular. In: Revista Brasileira de Direito Constitucional. n. ${ }^{\circ}$ 3. Jan/jun 2004.

ÁVILA, Caio Márcio de Britto. Mecanismos de democracia participativa no direito brasileiro. Dissertação de Mestrado, sob orientação do Professor Doutor Dalmo de Abreu Dallari, apresentada na Faculdade de Direito da Universidade de São Paulo, 2002.

AZEVEDO, Luiz Carlos de. Introdução à história do direito. $3^{\mathrm{a}}$ ed. rev. e ampl. São Paulo: Revista dos Tribunais, 2010.

BARROS, Sérgio Resende de. Contribuição dialética para o constitucionalismo. Campinas: Millenium Editora, 2007.

. Direitos humanos: paradoxo da civilização. Belo Horizonte: Del Rey, 2003. 
. Estado de legalidade. Apostila da disciplina "A negação do Estado de direito pelo Estado de legalidade”. Curso de Pós-Graduação da Faculdade de Direito da Universidade de São Paulo. $2^{\circ}$ semestre de 2009.

BASTOS, Celso Ribeiro. Curso de teoria do estado e ciência política. 2a . ed. São Paulo: Saraiva, 1989.

. Curso de direito constitucional. $18^{\mathrm{a}}$ ed. São Paulo: Saraiva, 1997.

BATTELLI, Maurice. Les institutions de démocratie directe en droit suisse et comparé moderne. Paris: Sirey, 1932.

BEÇAK, Rubens. Instrumentos de democracia representativa. Disponível em: $<$ http://www.conpedi.org.br/manaus/arquivos/anais/bh/rubens_becak.pdf $>$. Acesso em 18 jun. 2011.

BENEVIDES, Maria Victoria de Mesquita. A cidadania ativa: referendo, plebiscito e iniciativa popular. $2^{\text {a }}$ ed. São Paulo: Ática, 1991.

BERCOVICI, Gilberto. Referendo popular sobre matéria administrativa constitucionalidade. In: Revista Trimestral de Direito Público 49/50. São Paulo: Malheiros, 2005.

BESSETTE, Joseph. Deliberative democracy: the majority principle in republican government. In: GOLDWIN, Robert A. e SHAMBRA, William A. How democratic is the Constitution? Washington DC: American Enterprise Institute, 1980. pp. 102-116.

BOBBIO, Norberto. Liberalismo e democracia. São Paulo: Brasiliense, 1997.

Estado, governo, sociedade: para uma teoria geral da política. $2^{\mathrm{a}}$ ed. Trad. Marco Aurélio Nogueira. São Paulo: Paz e Terra, 1986.

A teoria das formas de governo. Trad. Sérgio Bath. $10^{\mathrm{a}}$ ed. Brasília: Editora Universidade de Brasília, 2000.

A era dos direitos. Trad. Carlos Nelson Coutinho. $9^{\mathrm{a}}$ ed. Rio de Janeiro: Campus, 1992. 
. e outros. Dicionário de política. $7^{\mathrm{a}}$ ed. Trad. João Ferreira [et al.]. Brasília:

Editora UnB, 1995.

BOHMAN, James. La democracia deliberativa y sus críticos. In: Metapolítica, México, Vol. 4, n. ${ }^{\circ}$ 14. Abr/jun 2000. pp.48-57.

BONAVIDES, Paulo. Ciência política. 17ª ed. São Paulo: Malheiros, 2010.

. História constitucional do Brasil. Brasília: OAB, 2002.

. Teoria constitucional da democracia participativa - por um direito constitucional de luta e resistência, por uma nova hermenêutica, por uma repolitização da legitimidade. $2^{\text {a }}$ ed. São Paulo: Malheiros, 2003.

BORGEAUD, Charles. Histoire du plébiscite - le plébiscite dans l'Antiquité: Grèce et Rome. Genebra: George H. Editeur, 1887.

BURDEAU, Georges. Droit constitutionnel et institutions politiques. $7^{\mathrm{a}}$ ed. Paris: Librairie Générale, 1957.

CAGGIANO, Monica Herman Salem. Sistemas eleitorais x representação política. Brasília: Senado Federal.

- Dos direitos políticos. In: Direito constitucional. Coord. Sônia Yuriko Kanashiro Tanaka. São Paulo: Malheiros, 2009.

. Democracia $x$ constitucionalismo. Um navio à deriva?. 14 jun. 2011.

Disponível em: <http://www.cepes.org.br/home/index.php?option=com_content\&view= article \&id=365:democracia-X-constitucionalismo-um-navio-a-deriva-\&catid=35: artigos \& Itemid=55>. Acesso em: 12 out. 2011.

CALIMAN, Auro Augusto. O recall no Estado de São Paulo. In: Revista de Informação Legislativa. Ano 42, n. ${ }^{\text {1 }}$ 165. Jan/mar 2005.

CANOTILHO, José Joaquim Gomes. Direito constitucional e teoria da Constituição. $7^{\mathrm{a}}$ ed. Coimbra: Almedina, 2003.

CARLYLE, R. W. e CARLYLE, A. J. A History of Medieval Political Theory in the West. Vol. II. Cap. IX. Blackwood: London, 1950. 
CENEVIVA, Walter. Plebiscito: direito e dever. São Paulo: Departamento Editorial da OABSP, 1993.

COHEN, Joshua. Reflections on Habermas on democracy. In: Ratio Juris, Vol. 12, n. ${ }^{\circ} 4$. Dez 1999. Disponível em: <http://dspace.mit.edu/bitstream/handle/1721.1/5452/Ratio-JurisVol12-No4.pdf>. Acesso em: 28 mar. 2013.

CONSTANT DE REQUEQUE, Henri-Benjamin. De la liberte des anciens comparée a celle des modernes - Discours prononcé a L'Athéné Royal de Paris. In: Colletion compléte des ouvragres. $4^{\circ}$ vol. Paris:Imprimerie de J. L. Chanson, 1820.

Constituição australiana. em: <http://www.aph.gov.au/About_Parliament/Senate/Powers_practice_n_procedures/Constituti on/chapter8>. Acesso em: 12 mai. 2012.

Constituição dinamarquesa (traduzida para o inglês). Disponível em: <http://www.euo.dk/euo_en/facts/constitution/>. Acesso em: 12 mai. 2012.

Constituição espanhola. Disponível em: <http://www.congreso.es/consti/constitucion/indice/index.htm>. Acesso em 23 fev. 2012.

Constituição francesa. Disponível em: <http://www.assembleenationale.fr/connaissance/constitution.asp>. Acesso em: 12 mai. 2012.

Constituição irlandesa. Disponível em: <http://www.constitution.ie/constitution-ofireland/default.asp>. Acesso em: 12 mai. 2012.

Constituição italiana. Disponível em: <http://www.governo.it/Governo/Costituzione/2_titolo1.html>. Acesso em: 1 fev. 2012.

Constituição portuguesa. Disponível em: <http://www.parlamento.pt/Legislacao/Paginas/ConstituicaoRepublicaPortuguesa.aspx>. Acesso em: 23 fev. 2012.

Constituição suíça. Disponível em: <http://www.admin.ch/ch/f/rs/101/index.html>. Acesso em: 10 abr. 2012.

COULANGES, Fustel. A cidade antiga. São Paulo: Martin Claret, 2006. 
CRUZ VILLALÓN, Pedro. El referéndum consultivo como modelo de racionalización constitucional. In: Revista de Estudios Políticos. Número 13. Madrid, 1980.

CUCOLO, Eduardo. "Maioria dos eleitores não acredita em eleições limpas no Brasil, diz Vox Populi”. Fonte: Folha Online. 12.ago.2008. Disponível em <http://www1.folha.uol.com.br/folha/brasil/ult96u432588.shtml>. Acesso em 18.jun.2011.

CUNHA FILHO, Francisco Humberto. A Participação popular na formação da vontade do Estado: um direito fundamental. In: GUERRA FILHO, Willis Santiago (Coor..). Dos direitos humanos aos direitos fundamentais. Porto Alegre: Livraria do Advogado, 1997.

DAHL, Robert. A. Poliarquia: participação e oposição. Trad. Celso Mauro Paciornik. São Paulo: Editora da Universidade de São Paulo, 1997.

DALLARI, Dalmo de Abreu. Elementos de teoria geral do Estado. São Paulo: Saraiva, 2000. A participação popular e suas conquistas. In: Cidadão constituinte: a saga das emendas populares. Rio de Janeiro: Paz e Terra, 1989.

DATA FOLHA. Piora a avaliação do Congresso Nacional. Fonte: Data Folha. 14 ago 2009. Disponível em: <http://datafolha.folha.uol.com.br/po/ver_po.php?session=901>. Acesso em: 18 jun 2011.

Declaração universal dos direitos humanos. Disponível em: <http://www.un.org/en/documents/udhr/>. Acesso em: 22 jul. 2011.

Dicionário Houaiss. Disponível em: 〈http://houaiss.uol.com.br〉.

DUVERGER, Maurice. Institutions politiques et droit constitutionnel. $11^{\mathrm{a}}$ ed. Paris: Presses Universitaires de France, 1955.

FALCÃO, Joaquim. Democracia, direito e terceiro setor. $2^{\mathrm{a}}$. ed. Rio de Janeiro: Editora FGV, 2006

FERREIRA FILHO, Manoel Gonçalves. Curso de direito constitucional. $28^{\mathrm{a}}$ ed. atual. São Paulo: Saraiva, 2002. 
. Idéias para uma nova constituição brasileira. São Paulo: Saraiva, 1987.

. A democracia possível. 5ª ed. São Paulo: Saraiva, 1979.

. Do processo legislativo. São Paulo: Saraiva, 2001.

. Comentários à Constituição Brasileira de 1988. Vol. 2. São Paulo: Saraiva,

1992.

FINLEY, Moses I. A política no mundo antigo. Trad. Álvaro Cabral. Rio de Janeiro: Zahar, 1985.

HABERMAS, Jürgen. Direito e democracia: entre facticidade e validade. Vol. II. Trad. Flávio Beno Siebeneichler. $1^{a}$ ed. reimp. Rio de Janeiro: Tempo Brasileiro, 2011.

. Para a reconstrução do materialismo histórico. Trad. Carlos Nelson Coutinho.

$2^{\mathrm{a}}$ ed. São Paulo: Brasiliense, 1990.

. Três modelos normativos de democracia. In: Lua Nova - Revista de cultura e política n. $36,1995 . \quad$ p. $43 . \quad$ Disponível em: <http://www.scielo.br/scielo.php?script=sci_arttext\&pid=S0102-64451995000200003\&lng= en\&nrm=iso>. Acesso em 21 mar. 2013.

HELD, David. Models of democracy. $3^{\text {a }}$ ed. Stanford: Stanford University Press, 2006.

HOBBES, Thomas. Leviatã, ou Matéria, forma e poder de um estado eclesiástico e civil. Org. Richard Tuck. Trad. João Paulo Monteiro [et al.]. 2a ed. São Paulo: Martins Fontes, 2008.

HOBSBAWM, Eric J. A Era das revoluções: Europa 1789-1848. Trad. Maria Tereza Lopes Teixeira e Marcos Penchel. 12ª ed. Rio de Janeiro: Paz e Terra, 2000.

JOUVENEL, Berttrand de. As origens do Estado Moderno - Uma história das ideias políticas no século XIX. Rio de Janeiro: Zahar Editores, 1978.

LIJPHART, Arend. Democracies. New Haven/London: Yale University Press, 1984.

LOCKE, John. Dois tratados sobre o governo. Trad. Julio Fischer. $2^{\text {a }}$ ed. São Paulo: Martins Fontes, 2005. 
LOEWENSTEIN, Karl. Teoría de la constitución. Trad. Alfredo Gallego Anabitarte. Barcelona: Ariel, 1982.

MANFRED, A. A grande revolução francesa. Trad. Maria Aparecida de Camargo e Antonia da Costa Simões. $2^{\text {a }}$ ed. São Paulo: Cone, 1986.

MALBERG, Raymond Carré de. Teoría general del Estado. Trad. José Lión Depetre. México: Fondo de Cultura Económica, 2001.

MEIRELLES, Hely Lopes. Direito Administrativo Brasileiro. $20^{\mathrm{a}}$ ed. Atual. por Eurico de Andrade Azevedo et al. São Paulo: Malheiros, 1995.

MELLO, Oswaldo Aranha Bandeira de. O referendum legislativo popular. São Paulo: Revista dos Tribunaes, 1935.

MENEZES, Aderson de. Teoria geral do Estado. $8^{\mathrm{a}}$ ed. $4^{\mathrm{a}}$ tiragem. Atual. José Lindoso. Rio de Janeiro: Forense, 2002.

MILL, John Stuart. Considerações sobre o governo representativo. $2^{\mathrm{a}}$ ed. Trad. E. Jacy Monteiro. São Paulo: Ibrasa, 1983.

MIRANDA, Jorge. Manual de direito constitucional. Tomo III. $5^{\mathrm{a}}$ ed. rev. atual. Coimbra: Coimbra Editora, 2004.

O referendo e o plebiscito: experiência portuguesa. In: Revista mexicana de derecho constitucional. Número 19. México: Universidad Nacional Autónoma de Mexico, 2008 .

MOISÉS, José Álvaro. Cidadania e participação: ensaio sobre o plebiscito, o referendo e a iniciativa popular na nova Constituição. São Paulo: Marco Zero, 1990.

MONTESQUIEU, Charles-Louis de Secondat. Do espírito das leis. Trad. Edson Bini. Bauru: EDIPRO, Série Clássicos, 2004.

PÉRICLES. Discurso de Péricles. Disponível em $<$ http://www.historianet.com.br/conteudo/default.aspx?codigo=1124>. Acesso em 23 mar. 2011.

PINTO, Djalma. Direito eleitoral. São Paulo, Atlas, 2003. 
PIOVESAN, Flávia. Direitos humanos e o direito constitucional internacional. São Paulo: Saraiva 2006.

ROCHA, Cármen Lúcia Antunes. O referendum e a representação democrática no Brasil. In: Revista de informação legislativa. Número 92. Brasília, 1986.

ROSANVALLON, Pierre. Le peuple introuvable - Historie de la représentation démocratique em France. Paris: Gallimard, 1998.

La démocratie inachevée - Histoire de la souveraineté du peuple em France. Paris: Gallimard, 2000.

ROUSSEAU, Jean-Jacques. Do contrato social. Trad. Lourdes Santos Machado. São Paulo: Nova Cultural, 1987.

RUFFIA, Paolo Biscaretti di. Direito constitucional: instituições de direito público. Trad. Maria Helena Diniz. São Paulo: Revista dos Tribunais, 1984.

SARLET, Ingo Wolfgang. A eficácia dos direitos fundamentais. $6^{\mathrm{a}}$ ed. Porto Alegre: Livraria do Advogado, 2006.

SARTORI, Giovanni. Teoria da democracia revisitada. Volume II - As questões clássicas. Trad. Dinah de Abreu Azevedo. São Paulo: Editora Ática, 1994.

SCHMITT, Carl. Democrazia e liberalismo. Trad. italiana Manuela Alessio. Milão: Giuffrè Editore, 2001.

SGARBI, Adrian. O referendo. Rio de Janeiro: Renovar, 1999.

SIEYÈS, Emmanuel. Qu'est-ce que le tiers état? Société de l'Histoire de la révolution française. Paris, 1888.

SILVA, Daniela Romanelli da. Democracia e direitos políticos. Campinas: Instituto de direitos políticos, 2005.

SOARES, Marcos Antônio Striquer. O plebiscito, o referendo e o exercício do poder. São Paulo: Instituto Brasileiro de Direito Constitucional, 1998. 
SOUZA, Luiz Henrique Boselli de. A correlação da efetividade das normas constitucionais com o suprimento das omissões normativas. Tese de Doutorado, sob orientação do Professor Doutor Sérgio Resende de Barros, apresentada na Faculdade de Direito da Universidade de São Paulo, 2010.

SOUZA JUNIOR, Cezar Saldanha. A crise da democracia no Brasil. Rio de Janeiro: Forense, 1978.

TÁCITO, Caio. Direito Administrativo. São Paulo: Saraiva, 1975.

TKEVELYAN, G. A revolução inglesa. Brasília: Editora UnB, 1982.

TOCQUEVILLE, Alexis de. Democracy in America. Trad. inglesa: Henry Reeve. Hazleton: Pennsylvania State University.

URBANO, Maria Benedita Malaquias Pires. O referendo. Perfil histórico-evolutivo do instituto. Configuração jurídica do referendo em Portugal. Coimbra: Coimbra Editora, 1998. 